\title{
Geologic Map of the Upper Arkansas River Valley Region, North-Central Colorado
}

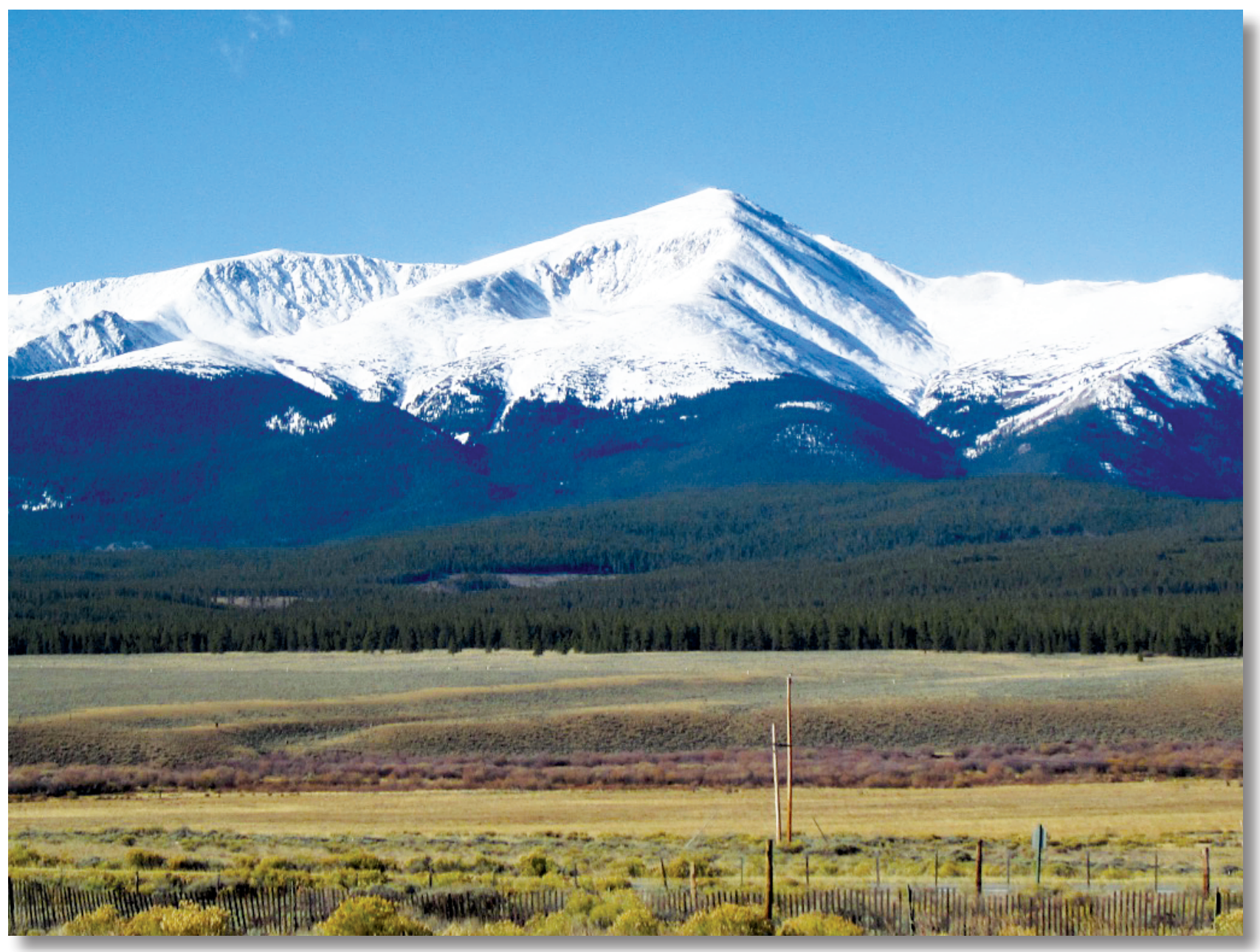

Pamphlet to accompany

Scientific Investigations Map 3382 
Cover front. View toward the southwest from the valley of the Arkansas River to Mount Elbert (middle skyline), the highest peak in the Sawatch Range as well as the highest in the State of Colorado. Sagebrush-covered terraces barely visible at the bottom of the photograph are underlain by outwash gravel of the Bull Lake glaciation. The tree-covered area, near the western margin of photograph, includes moraines composed of tills of the Pinedale, Bull Lake, and pre-Bull Lake age. Photograph by Ralph R. Shroba, September 18, 2011.

Cover back. Bighorn sheep on a large outcrop of Langhoff Gulch Granite, about 5 km north of the town of Granite, Colo. Photograph by K.S. Kellogg, July 2013. 


\section{Geologic Map of the Upper Arkansas River Valley Region, North-Central Colorado}

By Karl S. Kellogg, Ralph R. Shroba, Chester A. Ruleman, Robert G. Bohannon, William C. Mclntosh, Wayne R. Premo, Michael A. Cosca, Richard J. Moscati, and Theodore R. Brandt

Pamphlet to accompany

Scientific Investigations Map 3382 


\title{
U.S. Department of the Interior \\ RYAN K. ZINKE, Secretary
}

\section{U.S. Geological Survey William H. Werkheiser, Acting Director}

\author{
U.S. Geological Survey, Reston, Virginia: 2017
}

For more information on the USGS - the Federal source for science about the Earth, its natural and living resources, natural hazards, and the environment-visit https://www.usgs.gov or call 1-888-ASK-USGS.

For an overview of USGS information products, including maps, imagery, and publications, visit https://store.usgs.gov.

Any use of trade, firm, or product names is for descriptive purposes only and does not imply endorsement by the U.S. Government.

Although this information product, for the most part, is in the public domain, it also may contain copyrighted materials as noted in the text. Permission to reproduce copyrighted items must be secured from the copyright owner.

Suggested citation:

Kellogg, K.S., Shroba, R.R., Ruleman, C.A., Bohannon, R.G., McIntosh, W.C., Premo, W.R., Cosca, M.A.,

Moscati, R.J.,and Brandt, T.R., 2017, Geologic map of the upper Arkansas River valley region, north-central Colorado: U.S. Geological Survey Scientific Investigations Map 3382, pamphlet 70 p., 2 sheets, scale 1:50,000,

https://doi.org/10.3133/sim3382.

ScienceBase GIS data release files available at https://doi.org/10.5066/F75B00X0

ISSN 2329-132X (online) 


\section{Contents}

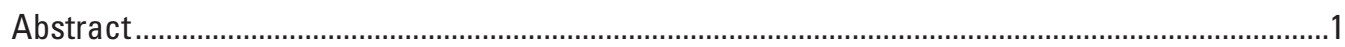

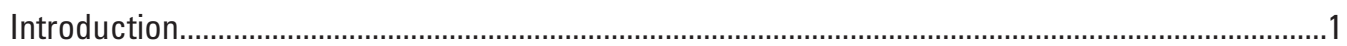

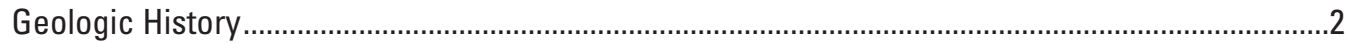

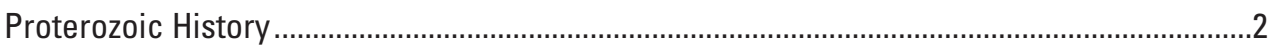

The Gunnison-Salida Volcano-Plutonic Belt.....................................................................

Paleoproterozoic Sedimentation, Volcanism, and Intrusive Activity ................................6

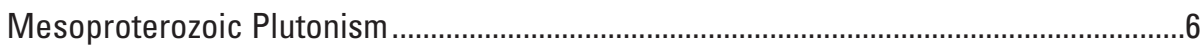

Paleozoic and Early Cretaceous Sedimentary History .............................................................

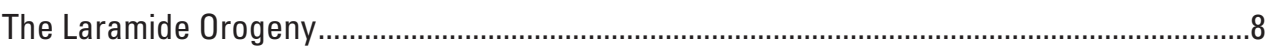

Late Cretaceous to Early Miocene Igneous Activity ............................................................

Magmatism Associated with Early Formation of the Northern Rio Grande Rift and the Upper Arkansas River Valley ..........................................................................11

Tectonism and Deposition Associated with Rio Grande Rifting.......................................11

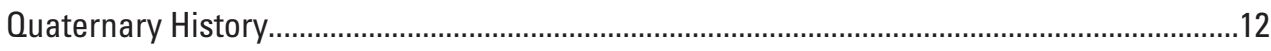

Glaciation and Glacial Deposits ............................................................................12

Catastrophic Outwash Floods and Their Deposits .........................................................13

Landslide Deposits and Sackung Features ...............................................................14

Neotectonics and Seismic Hazards ...................................................................................... 14

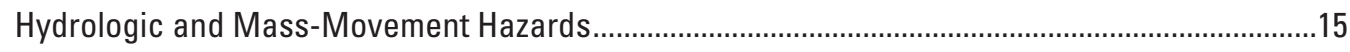

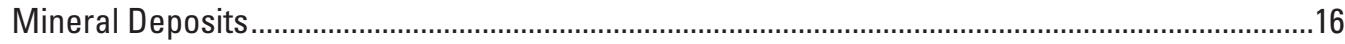

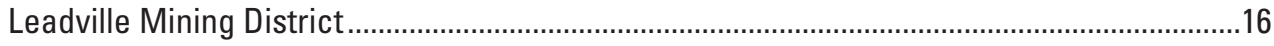

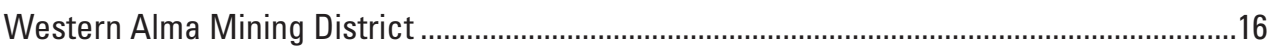

Two Bits and Granite Mining Districts.................................................................................16

Placer Gold Mining Areas Near Granite and Balltown ........................................................17

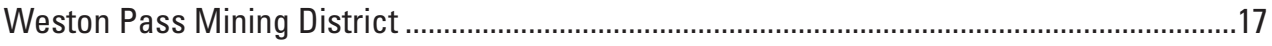

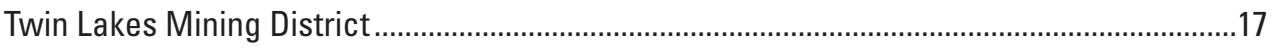

Sugar Loaf and St. Kevin Mining Districts.........................................................................17

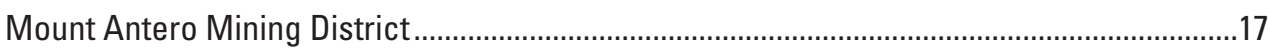

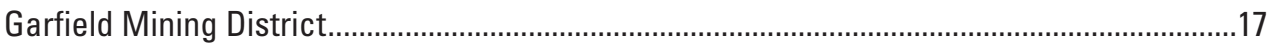

Sedalia Copper-Zinc Mining District ............................................................................... 18

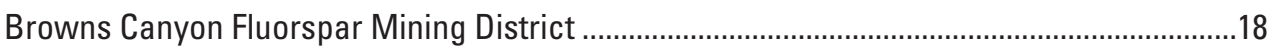

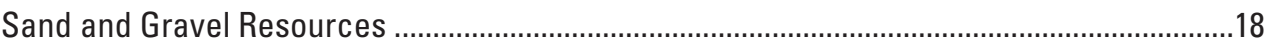

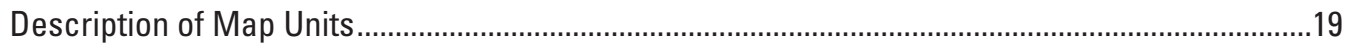

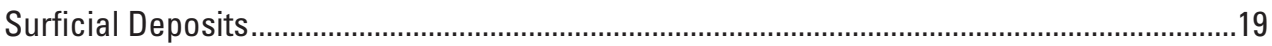

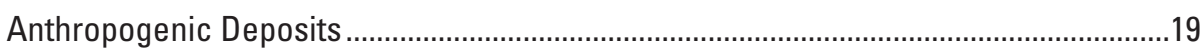

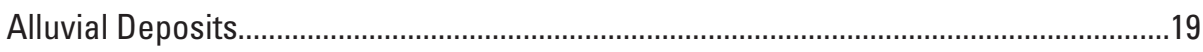

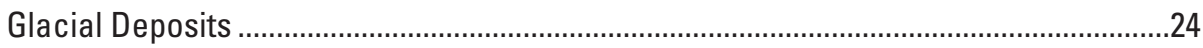

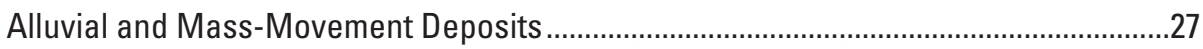

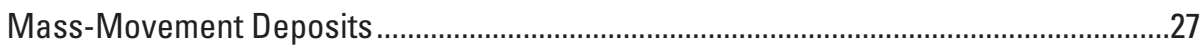

Eolian and Alluvial Deposits...........................................................................................

Mass-Movement and (or) Glacial Deposits ...................................................................29

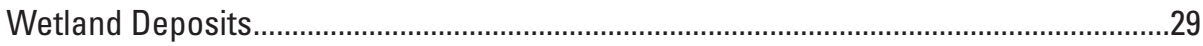

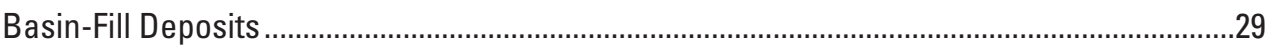


Oligocene and Eocene Volcanic and Mixed Volcanic,

Volcaniclastic, and Sedimentary Rocks .......................................................................

Volcanic Rocks Associated with Early Rio Grande Rifting ...............................................31

Pre-Rift Volcanic, Volcaniclastic, and Sedimentary Rocks ............................................34

Upper Eocene Volcanic Rocks of Buffalo Peaks Center.................................................38

Tertiary and Late Cretaceous Intrusive Rocks........................................................................

Rocks Associated with Early Rio Grande Rifting ...........................................................40

Leucogranite Suite of Mount Antero ..................................................................

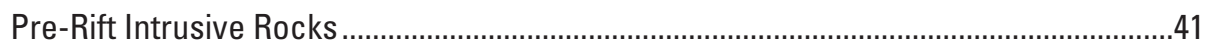

Rocks of the Mount Aetna Caldera (Early Oligocene or Late Eocene)....................42

Rocks of the Mount Princeton Batholith................................................................43

Eocene and Paleocene Intrusive Intermediate and Felsic Rocks...........................44

Regional Paleogene and Late Cretaceous Intrusive Rocks ....................................45

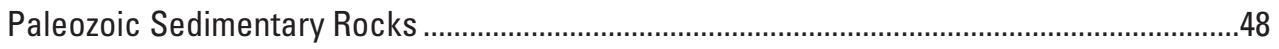

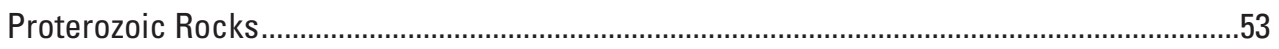

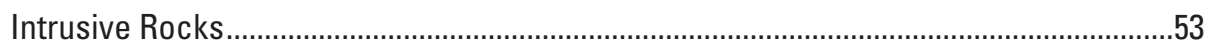

Paleoproterozoic Rocks of the Gunnison-Salida Volcano-Plutonic Belt.........................58

Metasedimentary and Metaigneous Rocks .................................................................59

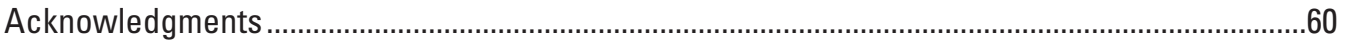

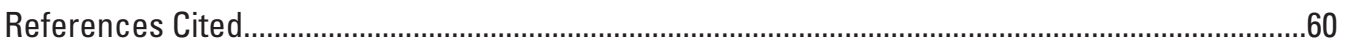

\section{Sheets}

1. Geologic Map of the Upper Arkansas River Valley Region, North-Central Colorado link

2. Correlation and List of Map Units for the Geologic Map of the Upper Arkansas River Valley Region, North-Central Colorado. link

\section{Figures}

1. A, Regional structure map of the mapped area. $B$, Map showing the principal basins in the northern part of the Rio Grande rift in Colorado, New Mexico, Texas,

2. Map of geographic setting of the map area. Map area outlined in red

3. Histogram showing distribution of U-Pb zircon ages from Proterozoic granitic rocks in the upper Arkansas River valley region.

4. Photograph of the north wall of a cirque (known locally as the "Horseshoe Cirque") on the east side of Horseshoe Mountain 11 kilometers $(\mathrm{km})$ southeast of Leadville, on the USGS Mount Sherman 7.5' quadrangle.

5. Histogram showing distribution of Tertiary and Late Cretaceous isotopic ages for the upper Arkansas River valley region

6. Schematic diagram showing the stratigraphic relations of volcanic, volcaniclastic, and basin-fill deposits east of the Arkansas River.

7. Photographs of $A$, View north of enormous granitic flood boulder on Qpf terrace deposits. $B$, View north of largest known flood boulder in the upper Arkansas River valley, on terrace surface underlain by unit Qpfo shown in fig. 8

8. Photograph of view northeast from Highway 24 of terraces along the Arkansas River about 4 km northwest of Riverside.... 
9. Photograph of a view to the north of the ash bed, about 1 meter [m] below the top of an exposed section of Dry Union Formation, just below the Qg2 outwash gravel deposit.

10. Photograph of view to north of Buffalo Peaks, which are composed mostly of andesite flows, andesite breccias, lahars, and welded tuff deposited on Mesoproterozoic granite.

11. Ternary diagram with quartz $(\mathrm{Q})$, potassium feldspar $(\mathrm{K})$, and plagioclase $(\mathrm{P})$ at apices, showing modal analysis and approximate fields for Proterozoic rocks.. . .54

\section{Tables}

1. Approximate height, in meters, of the top of gravelly stream alluvium of Pleistocene or Pliocene age above the Arkansas River.

2. Isotopic ages for rocks of the upper Arkansas River valley region

\section{Conversion Factors}

International System of Units to Inch/Pound

\begin{tabular}{lll}
\hline \multicolumn{1}{c}{ Multiply } & By & \multicolumn{1}{c}{ To obtain } \\
\hline millimeter $(\mathrm{mm})$ & Length & \\
centimeter $(\mathrm{cm})$ & 0.03937 & inch (in.) \\
meter $(\mathrm{m})$ & 0.3937 & inch (in.) \\
kilometer $(\mathrm{km})$ & 3.281 & foot (ft) \\
\hline square kilometer $\left(\mathrm{km}^{2}\right)$ & 0.6214 & mile (mi) \\
\hline cubic meter per second $\left(\mathrm{m}^{3} / \mathrm{s}\right)$ & Area & \\
\hline & 0.3861 & square mile $\left(\mathrm{mi}^{2}\right)$ \\
\hline metric ton $(\mathrm{t})$ & Flow rate & \\
\hline
\end{tabular}

U.S. customary units to International System of Units

\begin{tabular}{lcl}
\hline \multicolumn{1}{c}{ Multiply } & By & \multicolumn{1}{c}{ To obtain } \\
\hline ounce, avoirdupois $(\mathrm{oz})$ & Mass & gram $(\mathrm{g})$ \\
ton, short $(2,000 \mathrm{lb})$ & 28.35 & metric ton $(\mathrm{t})$ \\
\hline
\end{tabular}

Temperature in degrees Celsius $\left({ }^{\circ} \mathrm{C}\right)$ may be converted to degrees Fahrenheit $\left({ }^{\circ} \mathrm{F}\right)$ as ${ }^{\circ} \mathrm{F}=\left(1.8 \times{ }^{\circ} \mathrm{C}\right)+32$.

Temperature in degrees Fahrenheit $\left({ }^{\circ} \mathrm{F}\right)$ may be converted to degrees Celsius $\left({ }^{\circ} \mathrm{C}\right)$ as ${ }^{\circ} \mathrm{C}=\left({ }^{\circ} \mathrm{F}-32\right) / 1.8$.

Vertical coordinate information is referenced to the North American Vertical Datum of 1988 (NAVD 88).

Horizontal coordinate information is referenced to the North American Datum of 1927 (NAD 27).

Altitude, as used in this report, refers to distance above sea level. 


\section{Divisions of Quaternary, Neogene, and Paleogene time used in this report ${ }^{1}$}

\begin{tabular}{|c|c|c|c|}
\hline Period or subperiod & Epoch & & Age \\
\hline \multirow{4}{*}{ Quaternary } & Holocene & & $0-11.5 \mathrm{ka}$ \\
\hline & \multirow{3}{*}{ Pleistocene } & late & $11.5-132 \mathrm{ka}$ \\
\hline & & middle & $132-788 \mathrm{ka}$ \\
\hline & & early & $788 \mathrm{ka}-2.588 \mathrm{Ma}$ \\
\hline \multirow{2}{*}{ Neogene } & Pliocene & & $2.588-5.332 \mathrm{Ma}$ \\
\hline & Miocene & & $5.332-23.03 \mathrm{Ma}$ \\
\hline \multirow{3}{*}{ Paleogene } & Oligocene & & $23.03-33.9 \mathrm{Ma}$ \\
\hline & Eocene & & $33.9-55.8 \mathrm{Ma}$ \\
\hline & Paleocene & & $55.8-65.5 \mathrm{Ma}$ \\
\hline
\end{tabular}

\footnotetext{
${ }^{1}$ Ages of time boundaries are those of the U.S. Geological Survey Geologic Names Committee (2010) except those for the late-middle Pleistocene boundary and middle-early Pleistocene boundary, which are those of Richmond and Fullerton (1986). Ages are expressed in ka for kilo-annum (thousand years) and Ma for megaannum (million years).
} 


\title{
Geologic Map of the Upper Arkansas River Valley Region, North-Central Colorado
}

\author{
By Karl S. Kellogg, ${ }^{1}$ Ralph R. Shroba, ${ }^{1}$ Chester A. Ruleman, ${ }^{1}$ Robert G. Bohannon, ${ }^{1}$ William C. McIntosh, ${ }^{2}$ \\ Wayne R. Premo, ${ }^{1}$ Michael A. Cosca, ${ }^{1}$ Richard J. Moscati, ${ }^{1}$ and Theodore R. Brandt ${ }^{1}$
}

\section{Abstract}

This 1:50,000-scale U.S. Geological Survey geologic map represents a compilation of the most recent geologic studies of the upper Arkansas River valley between Leadville and Salida, Colorado. The valley is structurally controlled by an extensional fault system that forms part of the prominent northern Rio Grande rift, an intra-continental region of crustal extension. This report also incorporates new detailed geologic mapping of previously poorly understood areas within the map area and reinterprets previously studied areas. The mapped region extends into the Proterozoic metamorphic and intrusive rocks in the Sawatch Range west of the valley and the Mosquito Range to the east. Paleozoic rocks are preserved along the crest of the Mosquito Range, but most of them have been eroded from the Sawatch Range. Numerous new isotopic ages better constrain the timing of both Proterozoic intrusive events, Late Cretaceous to early Tertiary intrusive events, and Eocene and Miocene volcanic episodes, including widespread ignimbrite eruptions. The uranium-lead ages document extensive about 1,440-million years (Ma) granitic plutonism mostly north of Buena Vista that produced batholiths that intruded an older suite of about 1,760-Ma metamorphic rocks and about 1,700-Ma plutonic rocks. As a result of extension during the Neogene and possibly latest Paleogene, the graben underlying the valley is filled with thick basin-fill deposits (Dry Union Formation and older sediments), which occupy two subbasins separated by a bedrock high near the town of Granite. The Dry Union Formation has undergone deep erosion since the late Miocene or early Pliocene. During the Pleistocene, ongoing steam incision by the Arkansas River and its major tributaries has been interrupted by periodic aggradation. From Leadville south to Salida as many as seven mapped alluvial depositional units, which range in age from early to late Pleistocene, record periodic aggradational events along these streams that are commonly associated with deposition of glacial outwash or bouldery glacial-flood deposits. Many previously unrecognized Neogene and Quaternary faults,

\footnotetext{
${ }^{1}$ U.S. Geological Survey
}

${ }^{2} \mathrm{New}$ Mexico Institute of Mining and Technology some of the latter with possible Holocene displacement, have been identified on lidar (light detection and ranging) imagery which covers 59 percent of the map area. This imagery has also permitted more accurate remapping of glacial, fluvial, and mass-movement deposits and aided in the determination of their relative ages. Recently published ${ }^{10}$ beryllium $\left({ }^{10} \mathrm{Be}\right)$ cosmogenic surface-exposure ages, coupled with our new geologic mapping, have revealed the timing and rates of late Pleistocene deglaciation. Glacial dams that impounded the Arkansas River at Clear Creek and possibly at Pine Creek failed at least three times during the middle and late Pleistocene, resulting in catastrophic floods and deposition of enormous boulders and bouldery alluvium downstream; at least two failures occurred during the late Pleistocene during the Pinedale glaciation.

\section{Introduction}

This 1:50,000-scale U.S. Geological Survey (USGS) geologic map represents a compilation of the most recent geologic studies of the upper Arkansas River valley between Leadville and Salida, Colorado, including parts of Park, Lake, Chaffee, Eagle, and Pitkin Counties, plus a tiny sliver of Fremont County. Bedrock and surficial deposits within the map area record a wide variety of geologic processes including: metamorphism and plutonism during the Mesoproterozoic and Paleoproterozoic, periodic marine and nonmarine sedimentation during the Paleozoic, widespread intrusive and volcanic activity during the Late Cretaceous to early Miocene, basin development during the late Paleogene(?), and Neogene formation of the northern Rio Grande rift, extensive glaciation and catastrophic flooding during the Pleistocene, and deposition of post-glacial sediments during the Holocene. The map area contains one of the most complete sequences of Pleistocene till and outwash in central Colorado.

Many of the surficial deposits and deposits of the Neogene Dry Union Formation $(\mathrm{Nd})$ are poorly exposed within the map area. Surficial deposits that are limited in areal extent, as well as thin discontinuous colluvial deposits that locally mantle surficial deposits and bedrock units, were not mapped. Ages for most surficial deposits within the map area are based chiefly on 
relative heights of alluvial deposits above present stream channels, spatial relationships among till and coeval outwash deposits, the relative degree of erosional modification of depositional landforms, degree of soil development on landforms, and clast weathering on and within deposits (see Nelson and Shroba, 1998). Ages of some deposits in the map area have recently been determined by cosmogenic surface-exposure dating studies cited in this report.

Discovery of placer gold in late 1859 (Henderson, 1926) in surficial deposits near Leadville (near the mouth of California Gulch) and near the town of Granite (along Cache Creek and at the confluence of Clear Creek and the Arkansas River) rapidly ushered in a mining boom that brought numerous miners, along with many geologists, to the map area over the years. Early reports on the geology of the map area published by the U.S. Geological Survey include Hayden (1874), which includes a map of the moraines near the shores of Twin Lakes, Emmons and others (1886) on the geology of the Leadville mining district, and Capps (1909) on the Pleistocene glaciation of the Leadville 30 ' quadrangle.

This research was supported by the National Cooperative Geologic Mapping Program of the USGS. Kellogg compiled and revised the geology of the map area and wrote the mapunits descriptions and other text during 2009-2014. Shroba mapped many of the Quaternary and Neogene deposits with the aid of lidar (light detection and ranging) imagery, which covers 59 percent of the map area (see index of geologic mapping for area of lidar coverage) during 2014-2016 (AeroMetric, Inc., 2010, now Quantum Spatial) and wrote the Introduction, Flooding and Mass-Movement Hazards, and Placer Gold Mining Areas (near Granite and Balltown) sections of this report during 2014-2015. Ruleman and Shroba remapped Quaternary faults and lineaments in Quaternary deposits with the aid of the lidar imagery. Ruleman revised the section on Neotectonics and Seismic Hazards during 2015. Bohannon mapped the bedrock geology and structure in the USGS Mount Sherman 7.5' quadrangle during 2010-2012. McIntosh, Premo, Cosca, and Moscati determined the ages of Teritiary and Proterozoic bedrock units in the map area. Brandt generated slope and shaded-relief scenes from the lidar data that were critical for interpreting many geologic and shoreline features, and prepared the digital compilation of the geologic map. The Geographic Information System (GIS) data and related data files are available as a USGS data release in ScienceBase at https://doi.org/10.5066/F75B00XQ.

\section{Geologic History}

The geologic history of the map area can be divided into six major episodes: (1) Proterozoic history; (2) Paleozoic sedimentary history; (3) the Larimide Orogeny; (4) Late Cretaceous to Early Miocene igneous activity, (5) middle to late Tertiary development of the northern Rio Grande rift and associated mountain and basin development; and (6) Quaternary history.
The upper Arkansas River valley is a north-northwesttrending graben structurally controlled by mostly Miocene and younger normal faults. It lies in the northern part of the Rio Grande rift, a zone of crustal extension that extends south as far as Mexico (Chapin, 1979) and north as far as southern Wyoming (Tweto, 1979a; Mears, 1998) where the areal extent of the surficial deposits narrows substantially and the deposits are relatively thin (fig. $1 A, B$ ).

The upper Arkansas River valley consists of distinct southern and northern sub-basins, separated by a bedrock high near the town of Granite (fig 2). Paleoproterozoic rocks as old as about 1,780 Ma are exposed on both sides of the valley, in the Sawatch Range to the west and the Mosquito Range to the east. Paleozoic rocks as old as the Late Cambrian Sawatch Quartzite dip gently to the east near the crest of the Mosquito Range; similar rocks dip west in southern exposures in the Sawatch Range. This geometry is a result of both Late Cretaceous to early Eocene Laramide deformation and gradual uplift during Oligocene and younger Rio Grande rifting and tilting of the flank regions away from the axis of the uplift. A variety of Late Cretaceous to earliest Miocene volcanic and intrusive rocks is exposed in both ranges.

The array of terrace deposits exposed mostly on the western side of the valley was derived from three sources: (1) eastward-flowing tributary streams that head in the Sawatch Range (fig. 2), including the South Arkansas River, (2) westward-flowing tributary streams that head in the northern Mosquito Range, and (3) the southward-flowing Arkansas River. Glaciers that flowed down major drainages on the east flank of the Sawatch Range and on the western and eastern flanks of the Mosquito Range formed large moraine complexes during at least three major glacial episodes during the Pleistocene.

\section{Proterozoic History}

\section{The Gunnison-Salida Volcano-Plutonic Belt}

The Gunnison-Salida volcano-plutonic belt encompasses two sequences of volcanic and sedimentary rocks near Gunnison and Salida (Boardman, 1976; Bickford and Boardman, 1984; Boardman and Condie, 1986; Bickford and others, 1989; fig. 2). Only the sequence near Salida and Poncha Springs is exposed in the map area and consists of a bimodal assemblage of tholeiitic metabasalt, metarhyolite to metadacite, and interbedded metasedimentary rocks that were metamorphosed to upper greenschist to amphibolite facies and intruded by sheet-like masses of gabbro with compositions similar to those of the metabasalts, suggesting that they are cogenetic (Bickford and Boardman, 1984). These rocks were later intruded by plutons ranging in composition from quartz diorite to monzogranite. Many of the mafic volcanic rocks show well-preserved primary features such as vesiculation, pillows, and pillow breccias. Relict eutaxitic textures indicate many of the more felsic rocks are welded ash-flow tuffs. Metasedimentary rocks locally show well-preserved features 
$\boldsymbol{A}$

The Upper Arkansas River Valley

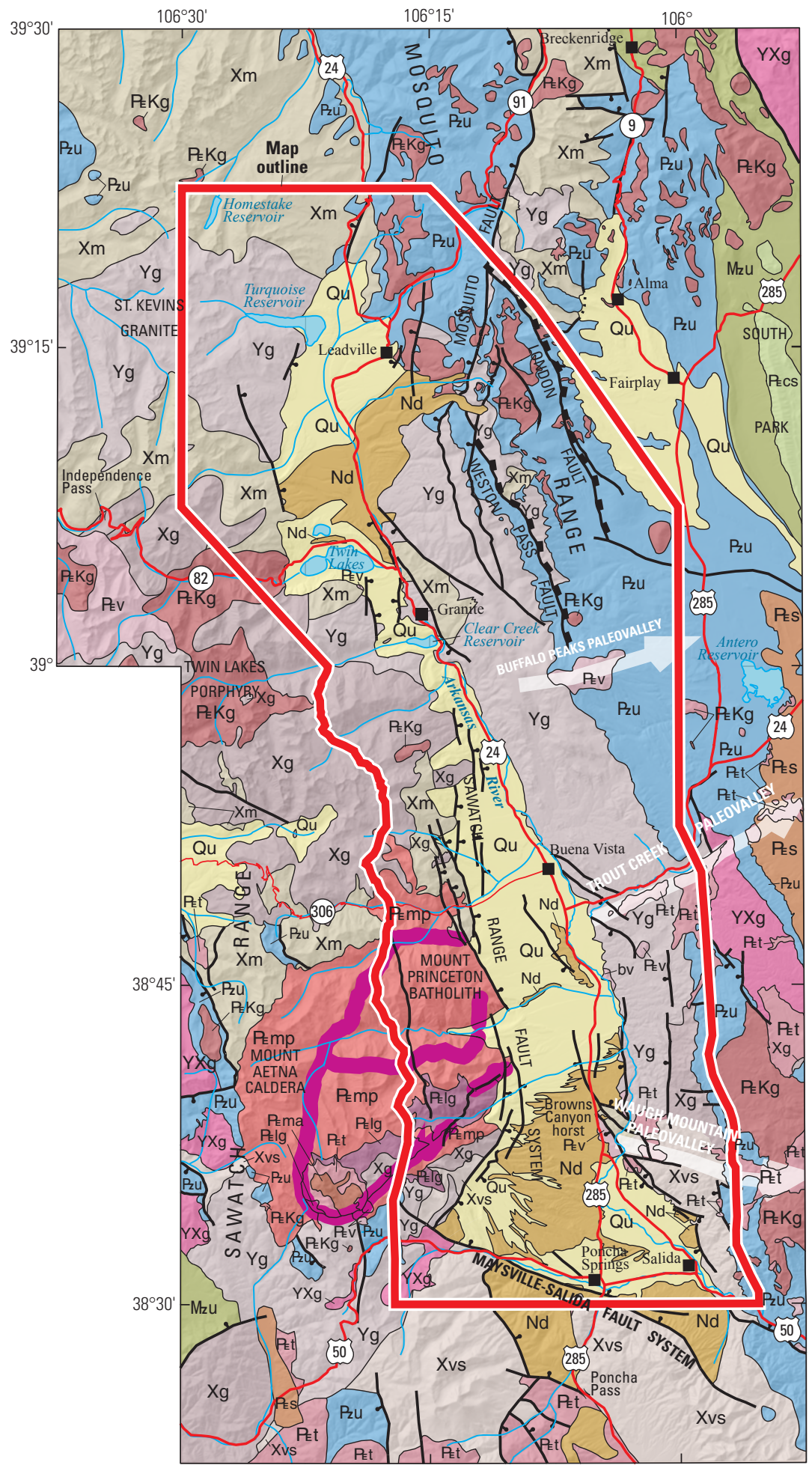

\section{EXPLANATION}

Surficial deposits (Quaternary)

Dry Union Formation and Santa Fe Group (Pliocene and Miocene)

Predominantly sedimentary deposits (Oligocene and Eocene)

Volcanic rocks (Oligocene and Eocene)

Ignimbrites of San Juan and Thirtynine Mile volcanic fields (lower Oligocene to middle Eocene)

$\mathrm{RKKg}$ Felsic, mostly porphyritic intrusive rocks (Oligocene to Late Cretaceous)

PElg Leucogranite suite of Mount Antero (early Oligocene)

PEma Monzogranite of Mount Aetna (late Eocene)

Pemp Rocks of Mount Princeton batholith (late Eocene)

PECS South Park Formation (Paleocene and Upper Cretaceous)

$\mathrm{Mzu}$ Upper Cretaceous to Triassic sedimentary rocks

$\mathrm{Pz}_{\mathrm{Z}}$ Paleozoic sedimentary rocks

$\mathrm{Yg}$ Mesoproterozoic granite and granodiorite

$\mathrm{YXg}$ Intrusive rocks of either Mesoproterozoic or Paleoproterozoic age-Mostly granitic rock

Intrusive rocks of Paleoproterozoic age

Metasedimentary rocks (Paleoproterozoic)

Xvs Metavolcanic and metasedimentary rocks of the Gunnison-Salida metamorphic belt Paleoproterozoic) Contact

I Normal fault-Bar and ball on downthrown side

- Reverse fault-Rectangles on upthrown block (hanging wall)

Fault-Type undetermined. Dashed where location is concealed

Mount Aetna cauldron ring-dike

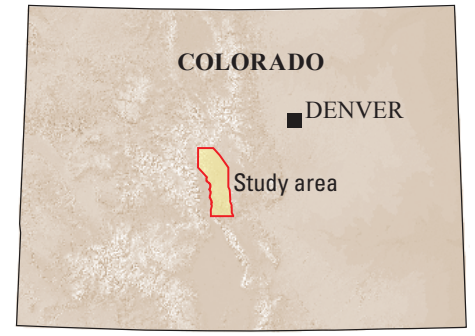

MAP LOCATION

Base modified from U.S. Geological Survey digital data, 2,000,000 Universal Transverse Mercator projection, zone 13N

North American Datum of 1927 (NAD27)

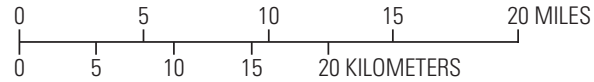

Figure 1. A, Regional structure map of the mapped area. 


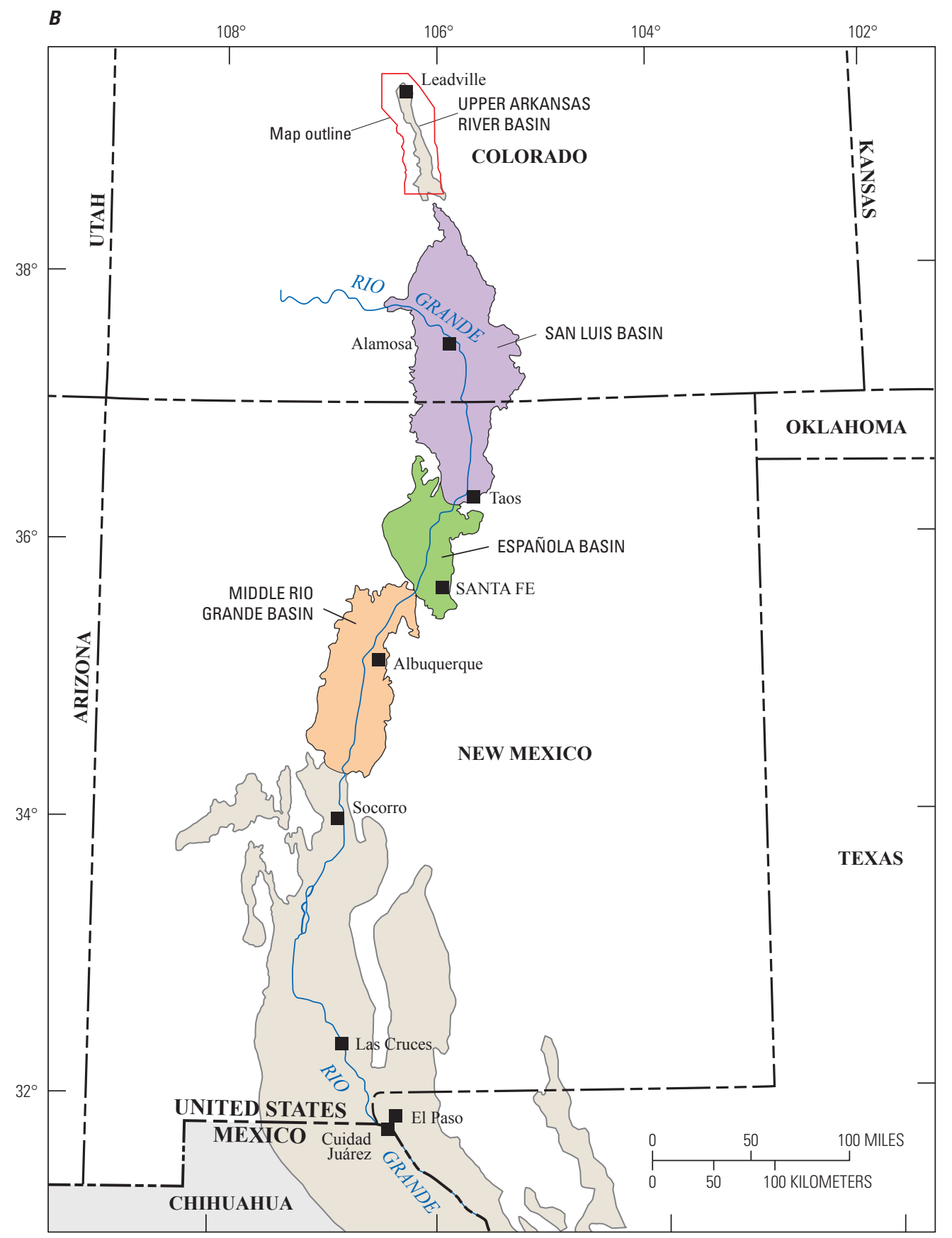

Figure 1. $B$, Map showing the principal basins in the northern part of the Rio Grande rift in Colorado, New Mexico, Texas, and northern Mexico (modified from Madole and others, 2016, after Hudson and Grauch, 2013).-Continued

such as graded beds, cross beds, and convolute bedding. These rocks are interpreted to have formed in a volcanic arc between about 1,770 to $1,750 \mathrm{Ma}$, followed by a second volcanic episode during which rhyolite to dacite were erupted between about 1,740 and 1,710 Ma (Bickford and Boardman, 1984; Bickford and others, 1989). Later metamorphism transformed these rocks into metavolcanic rocks that range in composition from metarhyolite to metadacite. Only rocks of the younger sequence have been dated in the map area.
The volcanic-arc model, however, is controversial. For example, the strongly bimodal composition of the volcanic rocks and the abundant coeval gabbroic sills suggest that these rocks formed in an extensional environment in an immature back-arc basin with sialic crust, with an arc somewhere to the south of the map area (Boardman and Condie, 1986). In addition, DeWitt and others (2010) suggest that the GunnisonSalida volcano-plutonic belt lies near the southern margin of a large marine sedimentary basin (their Poudre Basin) that 


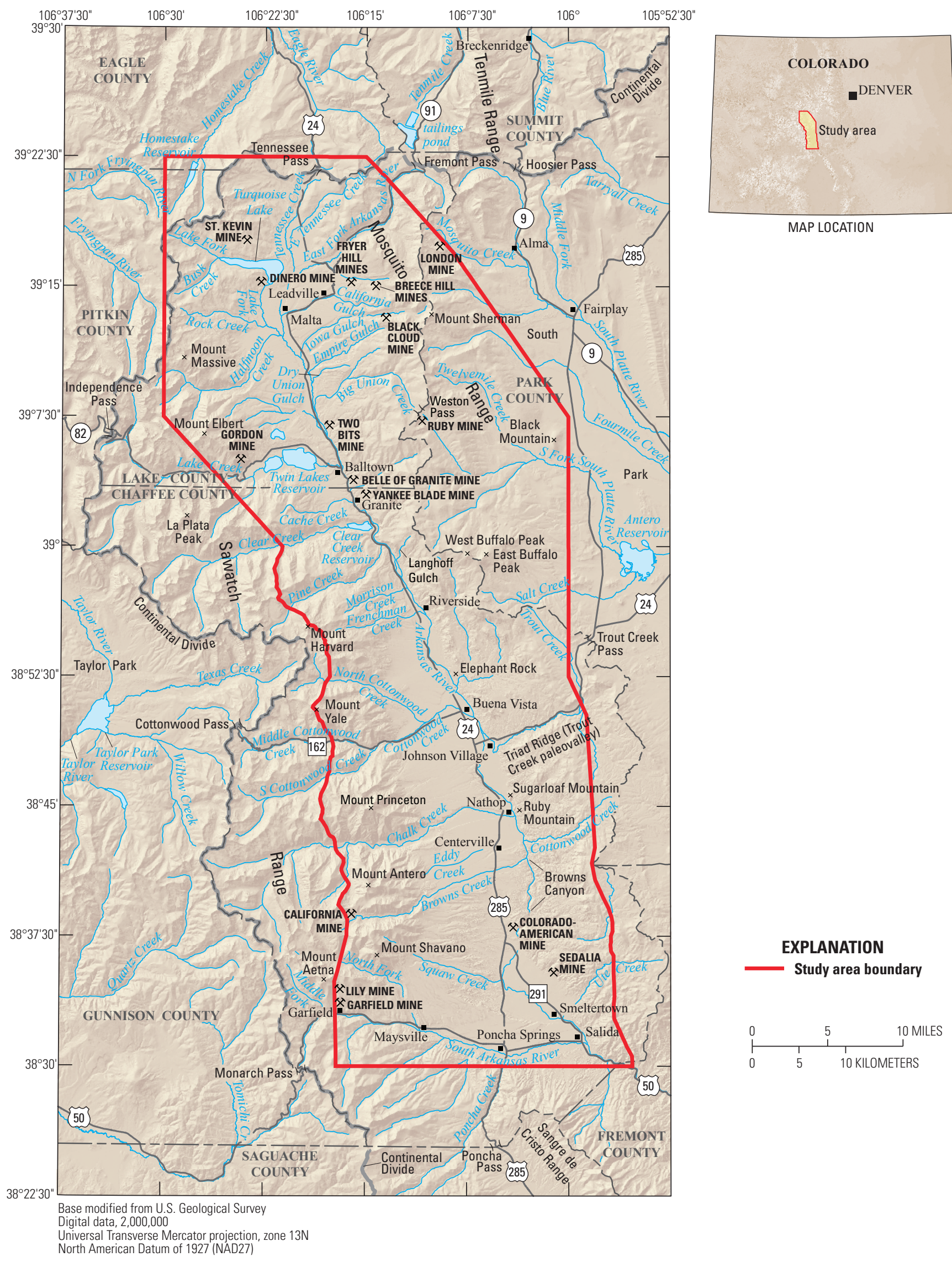

Figure 2. Geographic setting of the map area. Map area outlined in red. 


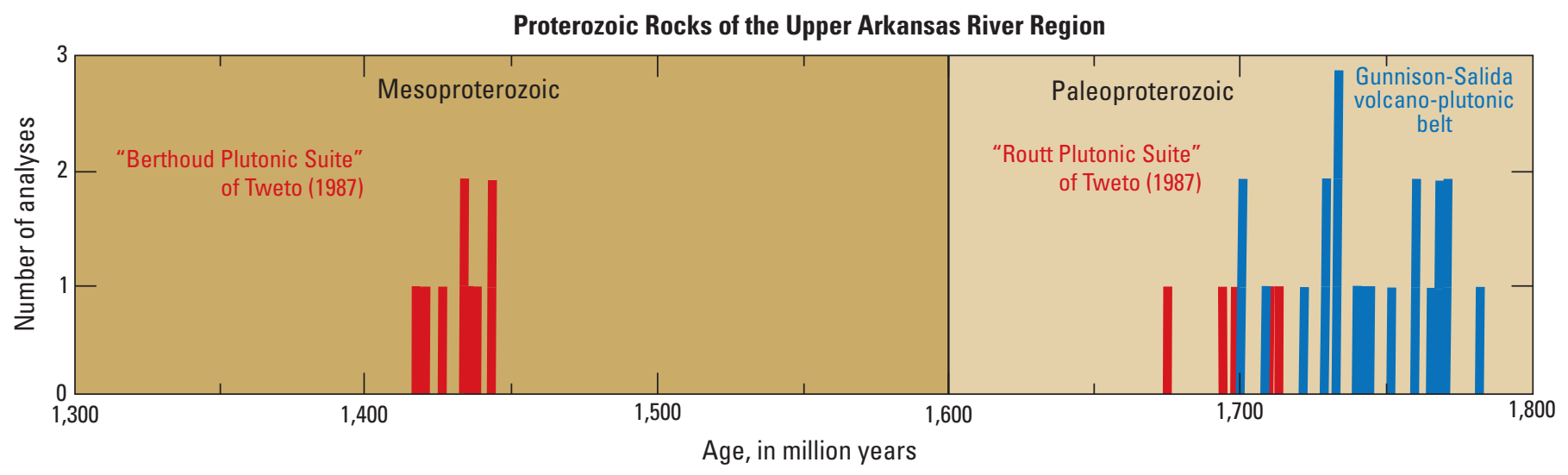

Figure 3. Histogram showing distribution of U-Pb zircon ages from Proterozoic granitic rocks in the upper Arkansas River valley region (Moscati and others, 2017; Kellogg and others, 2017). Ages define a bimodal distribution typical for the central Rocky Mountains. Red bars, Paleoproterozoic Routt Plutonic Suite and Mesoproterozoic Berthoud Plutonic Suite (Tweto, 1987); Blue bars, Gunnison-Salida volcano-plutonic belt (Bickford and others, 1989).

formed by rifting of a magmatic arc near the Wyoming border. Some of the metarhyolites and plutons contain detrital zircons as old as Neoarchean, suggesting derivation from partial melting of preexisting continental crustal rocks, a previously unrecognized southern extension of the Trans-Hudson and Penokean orogens (Hill and Bickford, 2001) (fig. 3).

\section{Paleoproterozoic Sedimentation, Volcanism, and Intrusive Activity}

Marine sediments and mafic and felsic volcanic rocks, and associated mostly mafic sills, were deposited or intruded in what is now the central Rocky Mountain region (including the map area) between about 1,780 and 1,730 Ma (Bickford and others, 1986; Boardman and Condie, 1986; Premo and others, 2007) and were generally metamorphosed to amphibolite grade. These rocks were then intruded and deformed by mostly calc-alkalic granitic rocks during a long orogenic episode that lasted about 110 my. These metasedimentary, metaintrusive, and metavolcanic rocks, mapped as biotite gneiss and minor amphibolite, are part of a Paleoproterozoic terrane called the Colorado province (Bickford and others, 1986), and are spatially separate from rocks of the Gunnison-Salida volcano-plutonic belt. The rocks of the Colorado province are generally interpreted to have formed following accretion of island arcs and back-arc basins to the southern margin of the Wyoming craton, which marks the southern edge of the Archean continent of Laurentia (Aleinikoff and others, 1993; Reed and others, 1993; Chamberlain, 1998). This $1,780-1,740$ Ma suturing event is called the Medicine Bow orogeny by Chamberlain (1998). Recent alternative models argue that island arc rocks are not present in the Colorado province and that the rocks were derived from extension of pre-existing crust of an unknown age (Hill and Bickford, 2001; Bickford and Hill, 2007; Bickford and others, 2008; DeWitt and others, 2010). The bimodal nature of the extrusive rocks (largely rhyolitic and dacitic tuffs and basalts) lends support for this alternative model.
Zircons from biotite gneiss from the Front Range region to the northeast, and the Blue River valley region to the north, are 1,785-1,740 Ma (Kellogg and others, 2008, 2011), which is the age of the source rock from which the zircons were derived and represents the maximum age of deposition of the sediment that ultimately became biotite gneiss. Similar rocks in the Salida region have zircon ages of about 1,730 Ma (Bickford and others, 1989), which is the metamorphic age of the rocks.

Following the $\sim 1,750-1,730$ Ma metamorphism, extensive batholiths and smaller bodies, referred to as the Paleoproterozoic Routt Plutonic Suite (Tweto, 1987; fig. 2), intruded the older layered rocks between about 1,735 Ma and 1,690 Ma. This suite is mostly granodiorite and monzogranite, but includes rocks as mafic as gabbro. These rocks include the Denny Creek, Kroenke, Music Mountain, and Mount Yale plutons.

\section{Mesoproterozoic Plutonism}

The most voluminous intrusive rocks in the map area are granitic rocks of the Mesoproterozoic Berthoud Plutonic Suite (Tweto, 1987). These rocks include the $\sim 1,435 \mathrm{Ma}$ Elephant Rock Granite (Yge), which was intruded by and was partially intermixed with the $\sim 1,435 \mathrm{Ma}$ Langhoff Gulch Granite (Ygl). Names for both of these rock units are now formalized (refer to the individual rock descriptions). The ages of these two units are statistically identical and are similar to the $\sim 1,430$ Ma granite of Granite (Ygrg), the 1,415 $15 \mathrm{Ma}$ granodiorite of Mount Elbert (Ygdm), the 1,425 $\pm 12 \mathrm{Ma}$ St. Kevin Granite (Ygs), the 1,414 \pm 20 Ma granodiorite of Mount Harvard (Ygdh), and the 1,441 \pm 9 Ma granite of Music Mountain (Ygm) (table 2). These plutonic rocks have similar mineralogy and represent a relatively short-lived, widespread episode of granitic plutonism. The Elephant Rock Granite was either molten or relatively ductile when the Langhoff Gulch Granite intruded, and contact zones are commonly gradational; 
a hybrid zone (Yhy) is mapped where the two are intimately intermixed. Both the Elephant Rock Granite and the Langhoff Gulch Granite locally are moderately to strongly foliated and contain zones of augen gneiss, indicating shearing, with foliation striking generally east or northeast and dipping north.

\section{Paleozoic and Early Cretaceous Sedimentary History}

Sometime during the latest Proterozoic, a widespread and poorly understood period of uplift and erosion exposed deep levels of the basement rocks across a nearly planar erosional surface that extended over much of what is now North America. Shallow seas covered this surface during most of the time between deposition of the Upper Cambrian Sawatch Quartzite and the Lower and Middle Pennsylvanian Belden Formation $(\mathrm{Pb})$. A brief period of emergence followed the deposition of the Mississippian Leadville Limestone (Ml; the dolomitic part of the Leadville Limestone is referred to locally as the Leadville Dolomite), resulting in the development of karst features (including caves) in the upper Leadville Limestone. On this irregular surface was locally deposited mostly windblown silt of the Lower Pennsylvanian Molas Formation, which, where it is preserved, it is included with the Leadville Limestone on the map. A complete and spectacular section of Upper Cambrian to Mississippian rocks is exposed 2.5 kilometers $(\mathrm{km})$ south of Mount Sherman on the east side Horseshoe Mountain in what is known locally as "Horseshoe Cirque" (fig. 4).

The ancestral Front Range, which lay to the east of the map area, was one of many late Paleozoic uplifts in the western and central United States, and began rising during the Middle Pennsylvanian (De Voto, 1980). All Paleozoic rocks were stripped from the central parts of the uplift areas and coarse sediment was shed southeastward toward the flanking

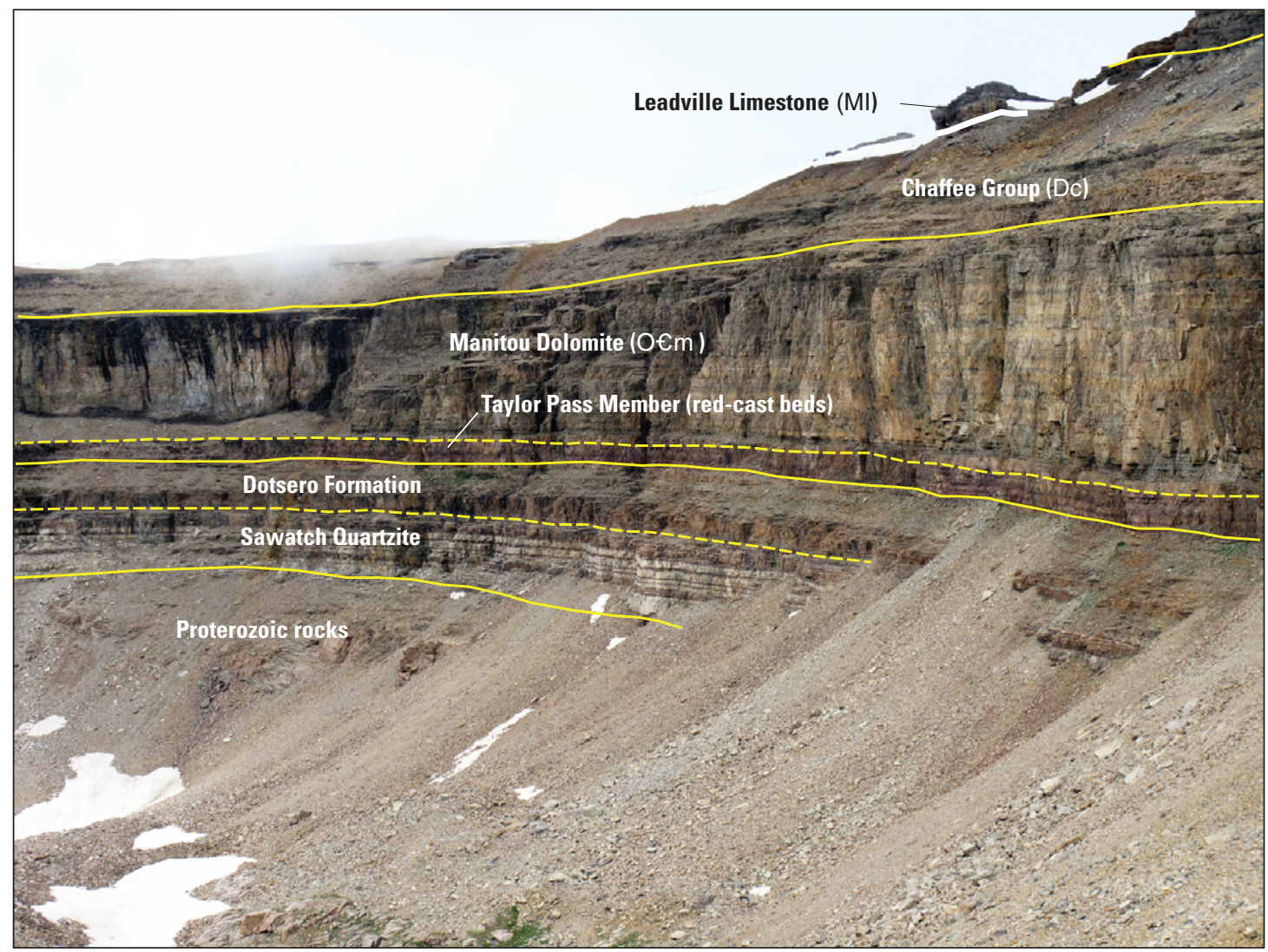

Figure 4. Photograph of the north wall of a cirque (known locally as the "Horseshoe Cirque") on the east side of Horseshoe Mountain 11 kilometers southeast of Leadville, on the U.S. Geological Survey Mount Sherman 7.5' quadrangle. The walls of the cirque show a well exposed Paleozoic section from the base of the Upper Cambrian Sawatch Quartzite to the lower part of the Lower Mississippian Leadville Limestone or Dolostone. Here, the Manitou Dolomite includes the Upper Cambrian Taylor Pass Member of Myrow and others (2003), so that the Cambrian-Ordovician boundary is within the Manitou Dolomite. Solid lines indicate a contact; dashed lines indicate an internal contact. The Dotsero Formation and the Sawatch Quartizite are mapped as a single undivided unit in this report (€ds). Vertical distance between base of Leadville Limestone and base of Sawatch Quartzite is about 195 m. Photograph by Karl Kellogg, 2011. 
Central Colorado trough, forming coarse-grained alluvial-fan and fluvial deposits of the Minturn (Pm) and Maroon (PPm) Formations. However, there apparently was no major uplift during this time in the area later occupied by the Sawatch Range. Clastic sedimentation was interrupted periodically by transgressive marine incursions and deposition of limestone, much of which was subsequently dolomitized. Grain size of the clastic deposits decrease toward the axis of the trough or basin, where coarser-grained clastic sediments interfinger with finer-grained clastic sediments and interbedded gypsum, such as those exposed in the northern part of the map area. After the region was once again eroded to a surface of low relief by Jurassic time, the waters of the Western Interior Seaway transgressed the region and a thousands-of-meters thick section of mostly Cretaceous marine sediments were deposited across the region. These Cretaceous marine sediments are prominently exposed to the north of the map area in the Blue River valley (Kellogg and others, 2011), to the east in the South Park basin (Ruleman and others, 2011), and to the west in the Piceance basin (Tweto, 1979b), but don't exist in the map area because all of these marine sedimentary rocks were removed from the map area by uplift and erosion during the next chapter in the geologic history, the Laramide orogeny.

\section{The Laramide Orogeny}

The Laramide orogeny was an approximate 20-millionyear (Late Cretaceous to early Eocene) period of crustal contraction, uplift, faulting, igneous activity, and erosion that marked a major period of mountain building, producing the early Rocky Mountains, although later (post late Eocene) uplift further greatly modified the mountain ranges. Gradual uplift of the Front Range and Sawatch Range-Mosquito Range regions occurred during the Late Cretaceous and the initiation of magmatic activity began about $70 \mathrm{Ma}$ and continued until the early Eocene, to about $50 \mathrm{Ma}$ (Tweto, 1975).

The Western Interior Seaway began to withdraw from the region after $69 \mathrm{Ma}$, the age of the youngest ammonite zone in the Late Cretaceous Pierre Shale on the eastern side of the Front Range (Scott and Cobban, 1965; Cobban, 1993; Obradovich, 1993). A sequence of upward-coarsening rocks as young as $64 \mathrm{Ma}$ documents this initial, rapid uplift and is dramatically exposed in and near Golden, just west of Denver (Kellogg and others, 2008 and references cited therein).

No synorogenic rocks of the Laramide orogeny are exposed in the map area, suggesting either that Laramide mountain building was relatively minor in the area of the Sawatch and Mosquito ranges as compared to the Front Range region, or that post-Laramide uplift removed all synorogenic rocks. Two west-directed reverse faults in the Mosquito Range (London fault and the Weston Pass fault, see fig. 1) suggest that synorogenic deposits may have been shed west and subsequently removed during flank uplift along the rift, although the possibility exists that such deposits are locally preserved at the base of the basin-fill under the Arkansas Valley.
Coarse-grained Laramide synorogenic deposits of the Paleocene and Upper Cretaceous South Park Formation are exposed to the east of the map area in South Park (see the Map of Regional Geology, fig. 1), but were shed from the westdirected Elkhorn thrust, which is located along the east side of South Park (the west side of the Front Range region; this process is summarized by Ruleman and others, 2011).

The upper Arkansas River valley lies approximately along the axis of the Laramide Sawatch uplift, a north-trending zone of basement highs. This coincidence is probably not fortuitous because the crestal zone of the uplift, similar to many other Laramide uplifts in the Rocky Mountain region (for example, Kellogg and others, 1995), was a localized zone of extension that was later exploited during overall crustal extension associated with formation of the Rio Grande rift (Kellogg, 1999).

Two high-angle reverse faults of probable Laramide age cut the Proterozoic and Paleozoic rocks east of the Arkansas River. The London fault cuts rocks as young as the $\sim 40 \mathrm{Ma}$ "gray porphyry group," suggesting late Laramide movement. The youngest rocks cut by the Weston Pass fault are late Paleozoic in age.

\section{Late Cretaceous to Early Miocene Igneous Activity}

Numerous Late Cretaceous and Tertiary dikes, stocks, and one batholith, ranging in composition from gabbro to monzogranite, intrude the older rocks in the map area. Many of these rocks are porphyritic. Ages of igneous activity fall into two distinct groups (fig. 4): (1) Late Cretaceous to Paleocene ( $\sim 70-60 \mathrm{Ma}$ ) intrusive rocks that accompanied Laramide uplift and deformation, and (2) late Eocene to early Miocene (mostly late Eocene to early Oligocene) intrusive and extrusive igneous rocks. Near Leadville, these two age groups are commonly defined by two groups of rhyolite to rhyodacite porphyry sills, dikes, and irregular intrusive bodies that were named by Emmons (Emmons and others, 1886) as the older "white porphyry group" including the $\sim 64 \mathrm{Ma}$ Pando Porphyry, and a younger, 40 Ma group "gray porphyry group" that includes the Johnson Gulch Porphyry ( $\mathrm{Regj})$, Sacramento Porphyry (Pegs), Eagle River Porphyry (PEer) and Lincoln Porphyry (Ptgl), although some rocks mapped as Lincoln Porphyry may be contemporaneous with those of the white porphyry group (fig. 5).

The older group also includes (1) the 64.6 $\pm 1.4 \mathrm{Ma}$ Twin Lakes Granodiorite (Petlg; Twin Lakes pluton of Fridrich and others, 1998; age corrected for revised standards of Kuiper and others, 2008), (2) mafic to intermediate-composition intrusive rocks $(\mathrm{P} E \mathrm{Km})$, including a cluster of small, Late Cretaceous (68.1 $\pm 0.9 \mathrm{Ma})$ gabbro stocks along and near Buffalo Creek, east of the Arkansas River, which hosts a low-grade sulfide deposit, and a 65.3 \pm 0.3 Ma hornblende monzodiorite stock and cogenetic dike near Morrison Creek, west of the Arkansas River (Kellogg and others, 2013), (3) the Late Cretaceous (70 Ma) Whitehorn Granodiorite (Kwg) along the eastern 
Isotopic Ages for Tertiary and Late Cretaceous Rocks of the Upper Arkansas River Valley Region

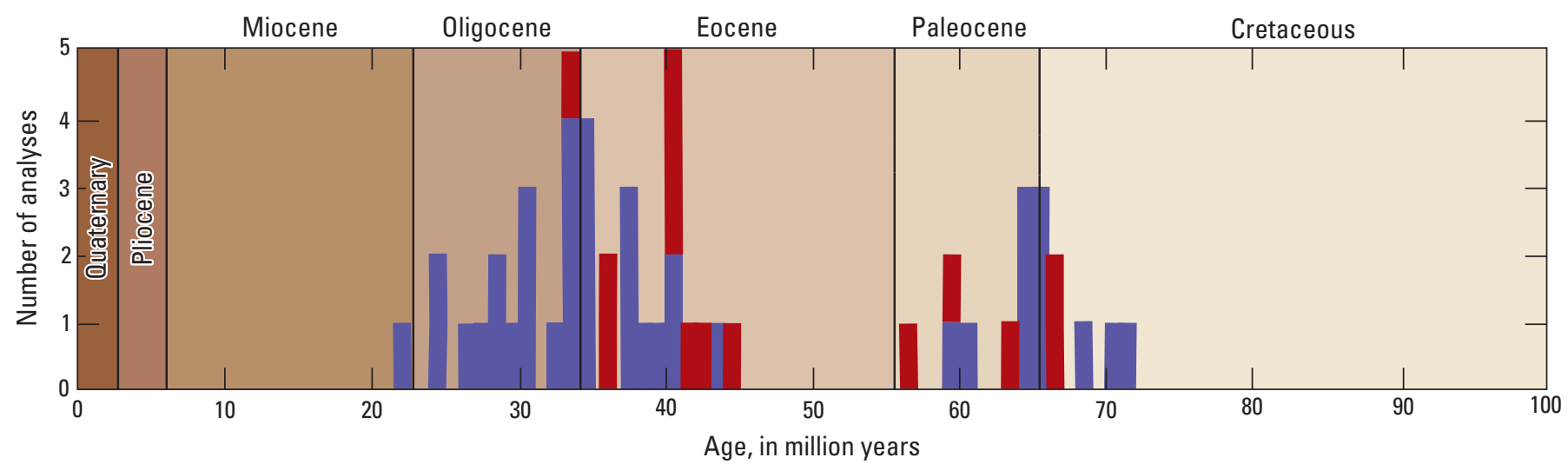

EXPLANATION

Upper Arkansas River valley region

Frisco-Breckenridge-South Park region

Figure 5. Histogram showing distribution of Tertiary and Late Cretaceous isotopic ages for the upper Arkansas River valley region (blue bars). These include all apatite fission-tract, ${ }^{40} \mathrm{Ar} /{ }^{39} \mathrm{Ar}$, potassium-argon (K-Ar), and uranium-lead (U-Pb) zircon ages. For comparison, similar ages are shown for the Breckenridge and Frisco region to the northwest of the map area (red bars). A hiatus from about $45 \mathrm{Ma}$ to $55 \mathrm{Ma}$ corresponds to a period of relative tectonic stability and extensive erosion in the central Rocky Mountains, during which the widespread Rocky Mountain erosion surface formed (Epis and Chapin, 1975).

margin of the map area near Salida, and (4) dacite and rhyolite dikes (the latter is quartz phyric in places), which has a potassium-argon (K-Ar) age of $65.3 \pm 2.4 \mathrm{Ma}$ from a quartz rhyolite dike near Hayden Gulch in the South Peak 7.5' quadrangle (Marvin and others, 1989).

From the late Paleocene to the late Eocene, the region was tectonically and magmatically quiescent and a late Eocene erosion surface of low to moderate relief developed across the region (Chapin and Epis, 1964; Epis and Chapin, 1975; Epis and others, 1980). This period ended with the onset of voluminous late Eocene to early Miocene magmatism and widespread renewed uplift, during which the Eocene volcanic rocks of the Thirtynine Mile volcanic field, exposed mostly east of the map area, were emplaced (Chapin and Epis, 1964; Epis and Chapin, 1975), as was the extensive San Juan volcanic field to the southwest (Lipman, 2000). Tuffs and lavas generally flowed eastward from sources in the Sawatch Range and were concentrated along three paleovalleys cut into the late Eocene erosion surface east of the Arkansas River: the Buffalo Peaks, Trout Creek, and Waugh Mountain paleochannels (Scott, 1975; Scott and others, 1975); see Map of Regional geology, fig. 1). The oldest volcanic rocks considered to occupy a paleovalley include those of the late Eocene (38 Ma) Buffalo Peaks volcanic complex. Rocks in this complex, probably the oldest extrusive rocks in the map area, include andesite flows and breccias, and interbedded tuffs of intermediate composition; enigmatic andesite intrusive bodies (units PEbn and PEai) just south of East Buffalo Peak may be feeders for at least some of these volcanic rocks. The $\sim 38$ Ma Buffalo Peaks volcanic complex, in which the andesitic lavas were named the Buffalo Peaks Andesite by Gould (1935), is representative of a period of andesitic and dacitic volcanism in the region, during which flows accumulated and are interspersed throughout the upper Eocene and Oligocene sedimentary and volcanic section. These flows include $\sim 34 \mathrm{Ma}$ basalts, andesite, and latite flows near Salida $\left(P_{E} a b\right)$, and similar intermediate volcanic rocks and small intrusive bodies both west and east of the Arkansas River.

The $\sim 38$ Ma composite tuff of Triad Ridge ( $\mathrm{P}$ tr) flowed eastward down the Trout Creek paleovalley (see Map of Regional Geology, fig. 1) and is overlain by the $\sim 37$ Ma Wall Mountain Tuff (Pewm), the Tallahassee Creek Conglomerate (PEtc), and the 36.1 Ma capping andesite porphyry of Triad Ridge ( $\mathrm{PECn}$ ). The Badger Creek Tuff ( $\mathrm{P} b \mathrm{bc}$ ), which erupted from the 34.8 Ma Mount Aetna caldera, flowed eastward down the broad Waugh Mountain paleovalley about $30 \mathrm{~km}$ south of Triad Ridge.

Figure 6 portrays a diagrammatic summary of the stratigraphy of volcanic and volcaniclastic rocks east of the Arkansas River.

Late Eocene to Oligocene intrusive activity is represented by several large plutons, including the $39.5-\mathrm{Ma}$ Johnson Gulch porphyry near Leadville. The largest intrusion is the granitic intrusive complex of the late Eocene Mount Princeton batholith in the Sawatch Range. Despite its size, the different units of the batholith all formed during one protracted period of intrusion and cooling (Shannon, 1988). The roughly elliptical-shaped batholith is about $38 \mathrm{~km}$ long by $22 \mathrm{~km}$ wide, although only the eastern portion of the pluton 


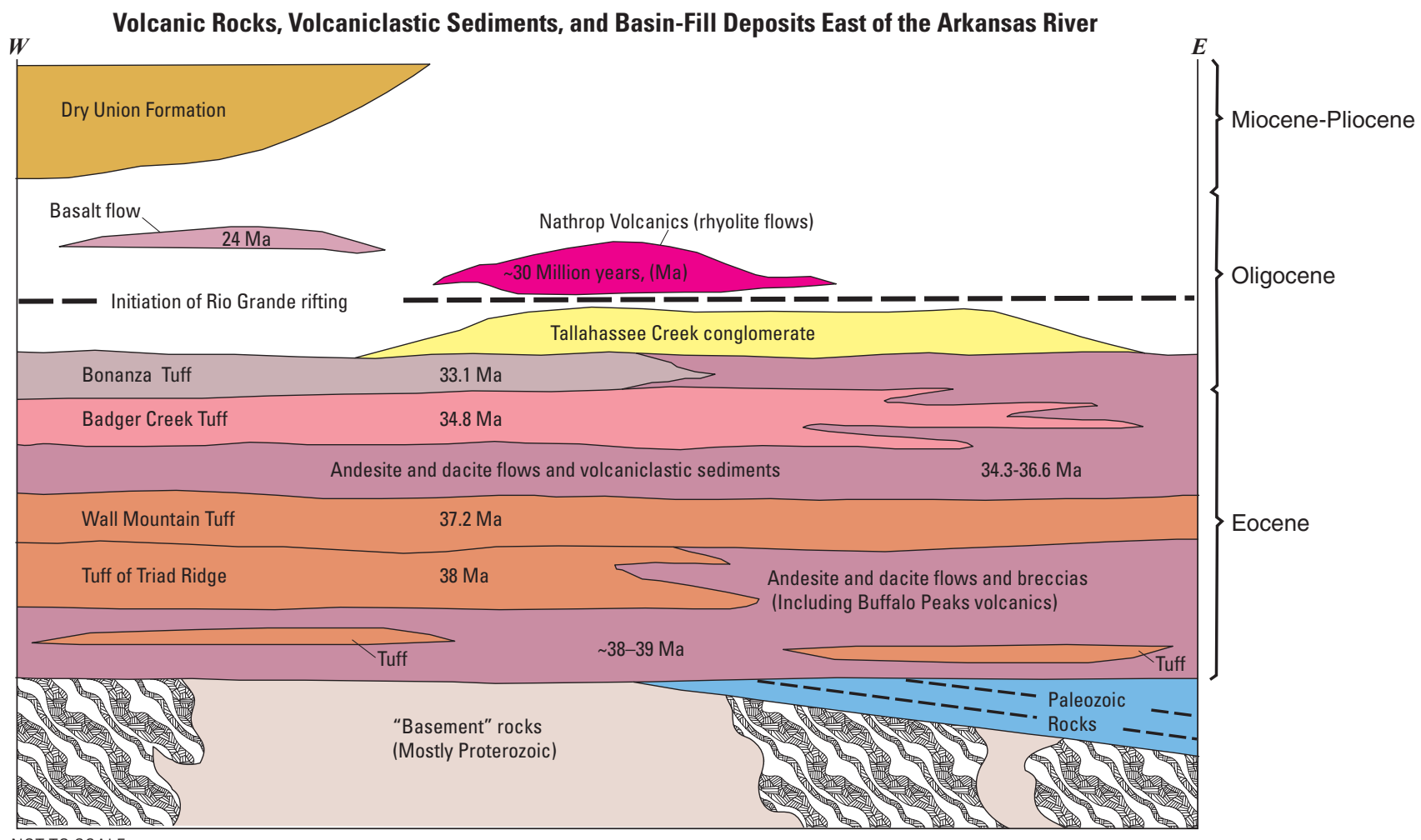

NOT TO SCALE

Figure 6. Schematic diagram showing the stratigraphic relations of volcanic, volcaniclastic, and basin-fill deposits east of the Arkansas River. Pattern in basement rocks indicates metamorphic rocks.

is exposed in the map area. The batholith is cut by the ring zone of the 34.5-Ma Mount Aetna caldera, which includes quartz latitic ring dikes ( $\left.P_{E} m a\right)$, intrusive breccia ( $\left.P_{E i b}\right)$ and associated ring-shaped shear zones (Shannon, 1988; McCalpin and Shannon, 2005). The batholith is also cut by bimodal, rift-related lamprophyre and rhyolite dikes, which are discussed below.

The reported ages for the Mount Princeton batholith are varied, probably due both to the protracted intrusive and cooling history and to problems with inheritance. Mills and Coleman (2013) report two ${ }^{206} \mathrm{~Pb} /{ }^{238} \mathrm{U}$ ages of $35.80 \pm 0.10 \mathrm{Ma}$ and 35.37 \pm 0.10 , while McCalpin and Shannon (2006) report a $\mathrm{Pb} / \mathrm{Th}$ age of $36.6 \pm 0.4 \mathrm{Ma}$. A mean ${ }^{40} \mathrm{Ar} /{ }^{39} \mathrm{Ar}$ age of $34.75 \pm 0.21 \mathrm{Ma}$ for the Mount Princeton intrusion reported by McIntosh and Chapin (2004; age corrected for revised standards of Kuiper and others, 2008) may have been slightly reset by heating during the emplacement of the younger 34.7 Ma Mount Aetna caldera complex (Shannon and McCalpin, 2006), or may simply reflect the long period of cooling following initial magmatic emplacement. The chemistry and petrography of the Wall Mountain Tuff, exposed extensively east of the Arkansas River, is similar to that of the Mount Princeton batholith complex, although the reported sanidine ${ }^{40} \mathrm{Ar} /{ }^{39} \mathrm{Ar}$ age of $37.25 \pm 0.10$ is significantly older (table 2, Zimmerer and McIntosh, 2012). The Wall Mountain Tuff most likely erupted from a now-eroded caldera that lay above the Mount Princeton batholith, and the younger ages for the batholith may reflect both the protracted cooling rate of the batholitic rocks as well as inheritance from the Mount Aetna caldera complex.

The $34.8 \mathrm{Ma}$ Mount Aetna caldera is a 13 by $27 \mathrm{~km}$ elliptical collapse structure totally within the Mount Princeton pluton. The caldera underwent at least two collapses; a 12-km-long, collapse structure is nested within the north end of a larger, 27-km-long, slightly older collapse structure (Shannon, 1988). Intracaldera tuff and megabreccia on and near Mount Aetna in the northwestern part of the USGS Garfield 7.5' quadrangle, are exposed just west of the map area (Shannon, 1988; Toulmin and Hammarstrom, 1990), but have been removed by erosion from 90 percent of the collapse area. Only the northeastern part of the younger Mount Aetna collapse structure is exposed in the map area, including a locally sheared quartz latite porphyry ring dike ( $\mathrm{P} \mathrm{ma}$ ) and adjacent shear zones and breccias ( $\mathrm{P}$ ib). The 34.8-Ma rhyodacitic Badger Creek Tuff, exposed east of the upper Arkansas River valley, is inferred to be an outflow tuff formed during the eruption of the Mount Aetna caldera (Shannon and others, 1987). The younger, 33.1-Ma Bonanza Tuff (Gribbles Park Tuff of Epis and Chapin, 1974) erupted from the Bonanza caldera, about $25 \mathrm{~km}$ southwest of Salida (McIntosh and Chapin, 2004; Lipman and others, 2015). 
Magmatism Associated with Early Formation of the Northern Rio Grande Rift and the Upper Arkansas River Valley

During the Oligocene, magmatism changed from calcalkaline (mostly andesitic to dacitic), related Andean-type plate margins, to an anorogenic, alkaline, chemically evolved bimodal (basalt and rhyolite) suite (Lipman and Mehnert, 1975; Shannon, 1988). The principal, pre-rift calc-alkaline intrusions are the $\sim 36$ Ma Mount Princeton batholith and the 34.8 Ma granitic rocks of the Mount Aetna caldera and the associated ring-dike assemblage. This transition from calc-alkaline to alkaline magmatism was accompanied by a change from a compressional crustal regime during the waning stages of the Laramide orogeny to one of crustal extension; the early stirrings of the northern Rio Grande rift occurred at this time. Evolved granites and their associated dikes, informally called the Mount Antero leucogranite suite by Shannon (1988) (characterized by almost white granitic rocks) include (1) the 31.4-Ma granite and granite dikes of North Fork (PEnf), near the North Fork of the South Arkansas River, (2) the 30.7-Ma leucogranite of the California Mine ( $\mathrm{PEcg}$ ), about $3 \mathrm{~km}$ southwest of Mount Antero (Worcester, 1919; Adams, 1953; Shannon, 1988), and (3) the 29.97 \pm 0.13 Ma Mount Antero Granite (main phase is unit Pagg). Some of these chemically evolved granites are well known for their pegmatites that locally contain specimens of aquamarine (blue beryl, the Colorado State gemstone), phenakite, and bertrandite (Adams, 1953; Sharp, 1976; Jacobson, 1979). These granites have similar major and trace-element compositions, mineralogy, and ages to the topaz-rhyolite lavas of the 29.25 to 30.74 Ma Nathrop Volcanics (units Penr and PEnt) and are considered to be part of the same magmatic suite (Shannon, 1988). Early syn-rift volcanism in the upper Arkansas River valley is about the same age as the oldest dated volcanic rocks interbedded with syn-rift sedimentary deposits in the San Luis Valley to the south, which are also about $30 \mathrm{Ma}$ (Miggins, 2002; Thompson and others, 1991; Chapin and Cather, 1994).

Numerous high-silica rhyolite porphyry dikes (unit Perp) and spessartite-bearing olivine-augite lamprophyre dikes (unit PEl; chemically similar to alkali basalt) comprise the bi-modal Cascadia dike swarm in the central Sawatch Range, that mostly intrude the late Eocene Mount Princeton batholith, and are spatially and temporally associated with the Mount Antero leucogranite suite. The dikes are interpreted as mafic members of a bimodal suite associated with rift magmatism (McCalpin and Shannon, 2005), emplaced during early Miocene or late Oligocene time during early stages of rifting. According to Shannon (1988), the high-silica rhyolite dikes, granites of the Mount Antero leucogranite suite, and the Nathrop topaz-bearing rhyolites form the felsic members of the bimodal assemblage. Two other dated rocks consistent with bimodal magmatism and early formation of the Rio Grande rift are a basaltic andesite porphyry flow (PEbf), about $2 \mathrm{~km}$ south of Twin
Lakes Reservoir, with a ${ }^{40} \mathrm{Ar} /{ }^{39} \mathrm{Ar}$ age of $24.12 \pm 0.12 \mathrm{Ma}$, and the nearby Clear Creek hypabyssal rhyolite porphyry plug (PErC), with a ${ }^{40} \mathrm{Ar} /{ }^{39} \mathrm{Ar}$ age of $24.3 \pm 0.6 \mathrm{Ma}$ (Shroba and others, 2014).

\section{Tectonism and Deposition Associated with Rio Grande Rifting}

Numerous, mostly down-to-the-east, normal faults bound the west side of the upper Arkansas River valley and comprise the Sawatch Range fault zone (SRFZ). These faults resulted from crustal extension that began during the Oligocene, contemporaneous with a change from calcalkaline to alkali volcanism about $30 \mathrm{Ma}$ (McIntosh and Chapin, 2004). Rifting began shortly before the deposition of the Browns Canyon Formation (NPEb) which locally contains plant fossils similar to those preserved in sediments of the Creede Formation in the San Juan Mountains to the southwest of the map area (Van Alstine and Cox, 1969) of late Oligocene age (Lanphere, 2000).

The preponderance of large-displacement, down-tothe-east faults on the west side of the valley suggests that progressively older units underlying near-surface valleyfloor sediments have been progressively tilted to the west. The SRFZ is part of this set of faults and is the major active structural element west and southwest of Buena Vista. A remarkably large normal fault surface of this fault zone, approximately 300 meters $(\mathrm{m})$ high, is well exposed and is formed on 36.6-Ma (McCalpin and Shannon, 2005) or 34.7-Ma (McIntosh and Chapin, 2004) monzogranite of the Mount Princeton batholith (unit PEmpm) just north of Chalk Creek on the USGS Mount Antero 7.5' quadrangle. The surface contains large trough-shaped "mega-crenulations" that plunge northeastward (down dip) and define large slickenlines. This prominent structural feature documents major fault movement after the emplacement of the batholith.

A few down-to-the-west normal faults also cut rocks on the east side of the valley and step up to the crest of the Mosquito Range (Tweto, 1975; Bohannon and Ruleman, 2013; Shroba and others, 2014). In addition, gravity data for the Salida region show a steep gravity gradient on the east side the valley (Case and Sikora, 1984), suggesting considerable normal displacement there.

The timing of uplift, uplift-related erosion and initial displacement on rift-bounding structures along the flanks of the Mosquito and Sawatch Ranges can be approximated by apatite fission-track (AFT) studies. Three AFT ages from the Twin

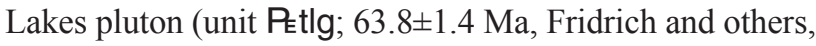
1998) in the Sawatch Range west of the Twin Lakes Reservoir are $20.0 \pm 2.9,19.9 \pm 4.4$, and $16.0 \pm 2.4 \mathrm{Ma}$ (early Miocene; Bryant and Naeser, 1980), which record the approximate time at which the rocks of the pluton cooled to about $100^{\circ} \mathrm{C}$, at a depth of about 2-2.5 km (Berkman and Watterson, 2010).

Based on gravity and resistivity studies, the southern end of the upper Arkansas River valley in the southern subbasin is underlain locally by at least $1,600 \mathrm{~m}$ of Miocene and 
lower Pliocene(?) basin fill, the upper part of which is the Dry Union Formation (Tweto, 1979a); the lower part of the basin-fill sequence is not exposed and is largely unknown, but may include sediments of the Browns Canyon Formation (NPb) of late Oligocene or Miocene age. Near Leadville, in the northern sub-basin, deposits of the Dry Union Formation (Nd) are about 1,000 $\mathrm{m}$ thick (Tweto, 1979a) and may be as much as 1,200 $\mathrm{m}$ (Tweto and Case, 1972). The formation consists locally of tuffaceous siltstone, sandstone, and conglomerate that were deposited during a period of widespread intermontane basin filling that is contemporaneous, in part, with the Santa Fe, Troublesome, Browns Park, North Park, and Arikaree Formations in adjacent or nearby basins (Izett, 1968; Steven, 2002; McMillan and others; 2006; Kellogg and others, 2011).

Exposed deposits of the Dry Union are as old as middle Miocene. Two ash beds south of Salida (locations $\mathrm{A}$ and $\mathrm{B}$; see table 2) have ${ }^{40} \mathrm{Ar} /{ }^{39} \mathrm{Ar}$ ages of $9.30 \pm 0.04 \mathrm{Ma}$ and 15.6 $\pm 0.3 \mathrm{Ma}$ (Morgan and Cosca, 2017). Ash beds in lacustrine deposits of the Dry Union Formation south of the Salida-Maysville fault (fig. 1) in the southeastern part of the USGS Maysville 7.5' quadrangle (Shannon and McCalpin, 2006) are 13.5 $\pm 0.2 \mathrm{Ma}$ and $14.4 \pm 1.4 \mathrm{Ma}$ (location C, table 2; Hubbard and others, 2001).

The age of the most recent faulting in the map area is not well constrained. Most scarps are highly degraded, suggesting that the last episode of movement on many of the faults in the area may be at least as old as middle Pleistocene. The entire Rio Grande rift region is currently remarkably aseismic as compared to other parts of Colorado, although a maximum intensity VI earthquake (magnitude unknown) cracked chimneys in Buena Vista in 1901 (Colorado Geological Survey, 2013). Whether this relatively low seismicity means that the existing faults in the upper Arkansas River valley are "locked" and potentially building stress, or whether the regional extensional stresses have relaxed during the Holocene and possibly during the late Pleistocene is poorly understood.

A fault strand of the SRFZ at Eddy Creek, just south of Chalk Creek, cuts till and outwash gravel of the Bull Lake glaciation and older outwash gravel of the Pinedale glaciation. Trenches excavated in fault scarps in outwash of the Bull Lake glaciation and in outwash of the Pinedale glaciation near the mouth of Cottonwood Creek and at Eddy Creek reveal at least six surface faulting events on the SRFZ since about 100-150 thousand years ago (ka) (Ostenaa and others, 1981), but evidence for a faulting event during Holocene is equivocal. Along the front of the Sawatch Range north of the Twin Lakes Reservoir, where glacial deposits cross the SRFZ, geomorphic relationships suggest down-dropping and burial of older glacial deposits likely occurred during the middle and late Pleistocene. In addition, faults along the eastern margin of the northern sub-basin have geomorphic characteristics that suggest displacement during the Pleistocene and Holocene (Bohannon and Ruleman, 2013) indicating periodic tectonic activity within the northeastern part of the Arkansas Valley graben complex.

\section{Quaternary History}

\section{Glaciation and Glacial Deposits}

Although valley glaciers did not form in the upper Arkansas River valley, large glaciers of pre-Bull Lake, Bull Lake, and Pinedale age formed in and flowed down major drainages on the east side of the Sawatch Range and both sides of the Mosquito Range. Some of these glaciers terminated in valleys within the ranges or slightly beyond the mouths of glaciated valleys on the floor of the upper Arkansas River valley and on the piedmont along the eastern margin of South Park. Sediment transported by these glaciers and their associated meltwater streams formed extensive moraine and outwash-terrace complexes. Glaciers commonly terminated at higher elevations in the Mosquito Range (2,990-3,110 m) than those on the east flank of the Sawatch Range (2,560-2,940 m). Glacial deposits of the Mosquito Range, thus, tend to be less extensive than those of the Sawatch Range. Differences in elevation and areal extent of glaciation in these ranges may be due in part to (1) a "rain shadow" effect caused by the Sawatch Range (prevailing winds are westerly) and (2) the Mosquito Range south of Weston Pass is not as high as the Sawatch Range at the same latitude. Glacial deposits along the western flank of the Mosquito Range extend from Big Union Creek, just north of Weston Pass, to the East Fork Arkansas River.

It is not known when valley glaciers first formed in the Sawatch Range and Mosquito Range. These earliest ice bodies may have formed during the latest Pliocene or early Pleistocene, possibly after the development of a thoroughgoing course of the Arkansas River downstream of Salida during the late Pliocene (Leonard and others, 2002).

Deposits interpreted as till of pre-Bull Lake age are mapped at 15 locations in the upper Arkansas River valley, over an area extending from the East Fork Arkansas River at Leadville (Tweto, 1974a; McCalpin, Funk, and others, 2012) to the North Fork South Arkansas River near Maysville (Scott and others, 1975; Shannon and McCalpin, 2006). However, much of the till of pre-Bull Lake age is likely buried beneath younger glacial deposits because cold (glacial) and warm (interglacial) climatic cycles prior to $900 \mathrm{ka}$ (marine oxygen isotope stage [MIS] 22) were of lower amplitude (lower global ice volume) and of much shorter duration (about 40 percent as long) than those after $900 \mathrm{ka}$ (Clark and Pollard, 1998). Marine oxygen isotope records show only two glacial episodes (MIS 12 and 16; about 475-424 ka and 675-621 ka, respectively; Lisiecki and Raymo, 2005) that were as severe (in terms of temperature and global ice volume) as those during the Bull Lake and Pinedale glaciations. This suggests that till and other ice-contact deposits formed during pre-Bull Lake glaciations in the Rocky Mountains prior to MIS 16 tend to be less extensive than those formed during the Bull Lake and Pinedale glaciations. Some of the older till of pre-Bull Lake age and associated, coeval, outwash gravel may have been deposited during two or possibly three glacial episodes recorded in cave sediments, dated by biostratigraphy and 
magnetostratigraphy at greater than 780 ka to less than $1 \mathrm{Ma}$, in Porcupine Cave in South Park about $7 \mathrm{~km}$ east of the map area (Barnosky and others, 2004).

Younger glacial deposits exposed in the map area include till and, locally, stratified drift, which form subdued moraines of the Bull Lake glaciation. Deposits of the Bull Lake glaciation in their type area in Wyoming are dated at about 170-120 ka (Sharp and others, 2003; Pierce, 2004; Licciardi and Pierce, 2008), but some may be as old as $190 \mathrm{ka}$ (Pierce, 2004). The deposits accumulated during one or more major cold climatic episodes during MIS 6 (190-130 ka, Lisiecki and Raymo, 2005) and probably during the early part of MIS 5 (130-70 ka, Lisiecki and Raymo, 2005; Pierce, 2004). Mapped deposits of the Bull Lake glaciation may locally include small, unmapped deposits of pre-Bull Lake glaciations.

The youngest and most extensive glacial deposits in the map area are those of the Pinedale glaciation (about 31-12 ka; Nelson and others, 1979; Madole, 1986; Benson and others, 2004, 2005; Madole, 2010). Compared to those formed during previous glaciations, moraines of Pinedale age have sharper crests and more hummocky surface morphology. Recent studies in the Sawatch Range and upper Arkansas River valley utilizing ${ }^{10} \mathrm{Be}$ surface-exposure dating have shown that deposits accumulated during the last glacial maximum range from $22.4 \pm 1.4 \mathrm{ka}$ to $19.5 \pm 1.8 \mathrm{ka}$ (Brugger, 2007; Briner, 2009; Mason and Ruleman, 2011; Young and others, 2011; Ruleman and others, 2013). These studies also show that Pinedale glaciers were receding from about $14.4 \pm 0.8 \mathrm{ka}$ (mean age) to $12.6 \pm 1.2 \mathrm{ka}$ (Brugger, 2007; Mason and Ruleman, 2011; Ruleman and others, 2013), with deglaciation rates of ice retreat of about 1 meter per year (m/yr) (Mason and Ruleman, 2011).

Coalescing fan-shaped surfaces and extensive alluvial aprons and plains, underlain by glacial outwash, formed along meltwater streams that issued from glaciers. Some of these gravelly deposits underlie surfaces that locally form stair-step-like flights of terraces owing to periodic alluviation followed by stream incision, which results in younger outwash gravel that is inset into and lower than older outwash gravel. The highest outwash gravel in the map area is as old as early Pleistocene; lower deposits of outwash gravel were deposited during younger glaciations during middle and late Pleistocene.

\section{Catastrophic Outwash Floods and Their Deposits}

Deposits of at least three major flooding events are recognized, all of which probably were produced by breakout floods from glacial dams at the mouth of Clear Creek, although glacial-dam breakouts at the mouth of Pine Creek may also have contributed to these floods. Glaciers that flowed down Clear and Pine Creeks during the Pinedale glaciation (and during a pre-Bull Lake glaciation) crossed the Arkansas River channel and terminated at the steep granite wall on the east side of the valley, which caused the glaciers to widen, thicken, merge, and form one or two large glacial dams that impounded the Arkansas River. The glacial lakes that formed upstream of this dam(s) were on the order of $200 \mathrm{~m}$ deep and $18 \mathrm{~km}$ long based on estimated heights $(200 \mathrm{~m})$ of the glacial dam(s) (Lee, 2010). Each time one of these ice dams failed, the glacial lake emptied catastrophically. Floodwater, with estimated peak discharges of between 21,000 and 65,000 cubic meters per second $\left(\mathrm{m}^{3} / \mathrm{s}\right)$ (Brugger and others, 2011), eroded distal portions of the end moraines and entrained large granitic blocks (some $>10 \mathrm{~m}$ in mean diameter) from the eastern valley wall of the Arkansas River, carrying them downstream with other debris. These glacial lakes must have been short lived, because no lacustrine deposits and no geomorphic features (such as shorelines) associated with these lakes were observed on the upstream side of the glacial dams within the USGS Granite 7.5' quadrangle (Shroba and others, 2014). This observation is contrary to an earlier interpretation that infers the existence of shoreline features and lake deposits upstream of the glacial dams (McCalpin, Funk, and others, 2012). Moreover, shoreline features that may be associated with one or more of these lakes were not observed on lidar imagery.

The timing of the first recognized flood that coursed down a relatively broad, flat valley of the Arkansas River is constrained by the age of the Lava Creek B ash $(639 \pm 2 \mathrm{ka}$; Lanphere and others, 2002), which locally overlies these flood deposits (unit Qpbf) on the east side of the Arkansas River, about $8 \mathrm{~km}$ north of Buena Vista.

Although the eastern limits of moraines of the Bull Lake glaciers along both Clear Creek and Pine Creek indicate that these Bull Lake glaciers were as large as, or larger than, than the Pinedale glaciers and likely dammed the Arkansas River (Lee, 2010), no clear evidence of a major flood during the Bull Lake glaciation has been observed in the upper Arkansas river valley downstream of Clear Creek and Pine Creek, although terrace deposits composed of outwash gravel of the Bull Lake glaciation (unit $\mathrm{Qgb}$ ) are locally preserved along the Arkansas River downstream of the inferred ice dam(s).

At least two breakout floods during the Pinedale glaciation are recognized. Boulders of the older flood deposit (unit Qpfo) are as long as $15 \mathrm{~m}$ and lie on a terrace about $20 \mathrm{~m}$ above the river; four of these boulders have a mean ${ }^{10} \mathrm{Be}$ surface-exposure age of about $19.6 \pm 0.6 \mathrm{ka}$ (Young and others, 2011), coeval with the Pinedale glaciation. These floods may have undercut the south-lateral moraines of Pine Creek, causing destabilization and recurrent movement of the large Pine Creek School landslide (Lee, 2010). Following deposition of unit Qpfo, the Arkansas River flowed briefly on the east side of the valley against Proterozoic rock producing relatively narrow channel deposits south of Tumble Creek.

Deposits of the last recognized outburst flood created a new boulder-mantled flood plain (Qpf) about 7-11 m below the flood gravel of Qpfo, mantling a terrace about 3-9 m above present level of the Arkansas River (Lee, 2010). ${ }^{10} \mathrm{Be}$ surface-exposure ages from four large (as long as about $10 \mathrm{~m}$ ) flood boulders on this terrace have a mean age of $17.8 \pm 0.5 \mathrm{ka}$ (Young and others, 2011), which indicates deposition during the Pinedale glaciation. The lake that preceded the last breakout flood may have had about the same dimensions as the previous 
lake, because boulders of similar size to those of the previous flood were deposited. When the dam failed, the flood deposited a sheet of boulders in the half-km-wide valley bottom.

Contrary to the interpretations of this report, Lee (2010) infers that the older, higher of the youngest two flood deposits (Qpfo) is of Bull Lake age, even though mean surface-exposure ages from four boulders in the youngest two flood deposits are different at 1 sigma $(\sigma)$ uncertainty and are only $\sim 1,900$ years apart. In this interpretation, (1) during the interglacial interval between the Bull Lake and Pinedale glaciations, the Arkansas River eroded about 7-11 $\mathrm{m}$ into the flood deposits inferred to be of Bull Lake age (unit Qpfo of this report), prior to the Pinedale glacial outbreak flood that deposited boulders on unit Qpf, and (2) the enormous boulders that were sampled for surfaceexposure dating on the higher of the two youngest two flood deposits were deposited by the same flood that deposited the boulders on unit Qpf.

Subsequent alluviation by tributary streams and deposition of debris-flow deposits built fan deposits (unit Qf) that locally buried many flood deposits along the valley margin and locally obscured terrace-gravel and flood-deposit relationships.

\section{Landslide Deposits and Sackung Features}

Landslide deposits are mapped at many localities in the map area, such as on the south side of the Buffalo Peaks and at the large Pine Creek School landslide just west of Highway 24, about $15 \mathrm{~km}$ north of Buena Vista. The latter landslide has moved recurrently; the eastern part of the landslide has very hummocky surface morphology. The numerous closed depressions (some partly filled by ponds and pond sediment) suggest that the eastern part of the landslide was recently active and locally may still be active. Many landslide deposits are mapped on moderate to steep slopes in mountainous areas throughout the map area.

Sackungen (German plural form of sackung) are deepseated bedrock fractures or small-scale grabens that form by deep-seated gravitational spreading of a ridge or large mass of weak bedrock within and near the map area (Kellogg, 2001; Kellogg and others, 2016). West of Turquoise Lake along Busk Creek in the northern part of the map area, a zone of sackungen contains several east-west-trending small grabens that have apparently moved (spread) northward and downslope approximately 8.3 centimeters $(\mathrm{cm})$ horizontally, with minimal vertical movement, between 1977 and 1999 (Varnes and others, 1989, 1990, 2000). Coe and others (2013) reoccupied and re-measured these sites during 1999-2013 and determined an average rate of horizontal movement of $1.0 \mathrm{~mm} / \mathrm{yr}$ for the upper graben and $3.6 \mathrm{~mm} / \mathrm{yr}$ downslope near the upper limit of glaciation (glacial trim line) during 1977-2013. These structures are most likely a result of post-glacial lateral spreading of an area of highly fractured and weak bedrock, enhanced at the surface by frost shattering and ice wedging. Extrapolating these rates of 0.38 centimeters per year $(\mathrm{cm} / \mathrm{yr}$ ) over a $12-13 \mathrm{ky}$ period since deglaciation (assuming a constant rate of movement) suggests a total extensional length during this period of time of about $45 \mathrm{~m}$.

\section{Neotectonics and Seismic Hazards}

The geomorphic expression of the Sawatch Range fault zone (SRFZ) along the east side of the Sawatch Range suggests recurrent tectonic activity during the Neogene and Quaternary. It is characterized by a linear, precipitous range front with locally well-defined basal faceted spurs. The range-bounding fault is divided into a southern and a northern section, separated by a crystalline bedrock high between Clear Creek and Pine Creek, just south of the town of Granite (Ostenaa and others, 1981). This bedrock high separates the Arkansas River graben into southern and northern sub-basins, which Ostenaa and others (1981) consider to be topographically distinct grabens that formed contemporaneously. The southern sub-basin extends $\sim 55 \mathrm{~km}$, from $20 \mathrm{~km}$ north of Buena Vista to the northern end of the Sangre de Cristo Range, just south of Salida. The northern sub-basin extends $\sim 30 \mathrm{~km}$ from the town of Granite to $\sim 7 \mathrm{~km}$ north of Leadville (Ostenaa and others, 1981). There is as much as $3 \mathrm{~km}$ of Neogene and Quaternary vertical displacement along the southern section of the SRFZ (Limbach, 1975) in the southern sub-basin. Previous mapping within the upper Arkansas River valley detected Quaternary fault displacement along both the northern and southern portions of the SRFZ, as well as along intra-basin faults and along the western flank of the Mosquito Range (Scott, 1975; Scott and others, 1975; Tweto and others, 1976). Kirkham and Rodgers (1981) describe the southern section of the SRFZ as a series of leftstepping, en echelon fault strands.

A paleoseismic investigation of a 29-km-long segment of the southern SRFZ documented as many as six surface rupturing events during the past 100-150 ky in trench excavations at Cottonwood Creek and at Eddy Creek, just south of Chalk Creek (Ostenaa and others, 1980, 1981). Evidence for Holocene faulting is equivocal, although Colman and others (1985) estimated that the last major movement along the southern portion of the SRFZ occurred between 11 and $7 \mathrm{ka}$, based on fault-scarp regression data. The characteristic displacement per event along the fault segment investigated by Ostenaa and others $(1980,1981)$ is $0.2-0.3 \mathrm{~m}$, and total displacements of Pinedale and Bull Lake deposits were 2 and $10 \mathrm{~m}$, respectively, which is significantly less than fault displacements measured in the same general region by McCalpin and Shannon (2005), who report that pre-Bull Lake, Bull Lake, and Pinedale deposits were displaced approximately $20-35 \mathrm{~m}, 5-18 \mathrm{~m}$, and 3-4 m, respectively. Lidar imagery used in the present study revealed previously unrecognized scarps formed in deposits of outwash gravel of the Pinedale glaciation (Qgp) along Cottonwood Creek and North Cottonwood Creek. We did not recognize any displacement of Holocene deposits while doing limited fieldwork for this report. Southwest of Buena Vista, McCalpin and Shannon (2005) mapped alluvial deposits of Bull Lake age and pre-Bull Lake age near Maxwell Park as being displaced by an antithetic west-dipping intra-basin fault. The length of this fault segment is only about $5 \mathrm{~km}$, so it is probably an antithetic, 
subsidiary fault that may have ruptured co-seismically with events on the larger SRFZ. The northern section of the SRFZ is characterized by a more subdued range front and by limited evidence of late Pleistocene tectonic activity. Ostenaa and others (1981) did not observe any late Quaternary fault scarps along this section of the fault zone. However, the present study identified two prominent, southeast-facing fault scarps on the south side of Rock Creek that are formed in till of Bull Lake age (Qtb), but not in adjacent till of Pinedale age (Qtp). These fault scarps suggest at least one surface-rupturing event during the past 100-150 ky, and that the latest episode of tectonic activity during the middle or late Pleistocene was not limited to the southern section of the SRFZ.

Some of the moraines formed by glaciers that flowed down valleys on the eastern flank of the Sawatch Range have significantly different orientations west and east of the range front. Moraines west of the range front, such as those along Halfmoon Creek southwest of Leadville, along Browns Creek southwest of Nathrop, and moraines of the Bull Lake glaciation on the north side of Pine Creek south of Granite, are oriented easterly and northeasterly, but change to northeasterly and northerly, east of the range front. It is not known if these abrupt, roughly $45^{\circ}$ differences in the orientations of these moraines at the range front are related to structural control or the buttressing effects of older glacial deposits on the flow-paths of younger glacial ice. In addition, numerous lineaments are mapped along the northern section of the SRFZ within the footwall of the main range-bounding fault. North of Halfmoon Creek northward to Tennessee Creek, these lineaments generally trend north and are aligned with well-defined escarpments formed in tills of the Bull Lake glaciation and the Pinedale glaciation. The presence of these escarpments in areas of thick glacial till deposited during these two glaciations suggests periodic displacement on these faults during the late Pleistocene and possibly during the middle Pleistocene, which resulted in the development of till-mantled bedrock benches.

The east side of the rift is bound chiefly by west-dipping down-to-the-west normal faults that step up to the crest of the Mosquito Range. Scott (1975) and Tweto and others (1978) mapped the western-most strands of this fault zone and inferred that the displacement probably predated the Bull Lake glaciation. Bohannon and Ruleman (2013) mapped linear escarpments in young colluvial and alluvial deposits aligned with springs and seeps on the western flank of the Mosquito Range. These escarpments may be related to displacement during the Holocene along eastern, basin-margin faults. Kirkham and Rodgers (1981) describe Pleistocene glacial deposits that are offset as much as $12 \mathrm{~m}$, with the youngest event during the late Pleistocene, but they do not report any evidence of Holocene displacement. The lateral extent and coseismic behavior of individual fault strands of the eastern basin-margin fault zone is uncertain; thus, their most recent events, recurrence intervals, and Pleistocene slip rates are unknown.
Historic seismicity in the inter-mountain west has demonstrated that the seismogenic crust is approximately $13-15 \mathrm{~km}$ deep. Based on this depth, displacement per event, and the inferred rupture length of $29 \mathrm{~km}$ along the southern portion of the SRFZ, the moment magnitude $\left(\mathrm{M}_{\mathrm{w}}\right)$ for a single event would be 6.3 (Osetenaa and others, 1981). However, a more recent study suggests the maximum $\mathrm{M}_{\mathrm{w}}$ for a single event along the southern Sawatch Range fault would be 7.0, which is more consistent with historic analogs within the Basin and Range province (for example, 1959 M7.5 Hebgen Lake earthquake in Montana, and 1983 M7.3 Borah Peak earthquake in Idaho) (U.S. Geological Survey, 2008; Petersen and others, 2014).

\section{Hydrologic and Mass-Movement Hazards}

Hydrologic and mass-movement processes periodically affect use of the land and locally may be of concern regarding the stability of buildings and infrastructure, chiefly in lowlying areas along and near streams and locally in areas on or below gentle to steep slopes. Low-lying areas along and near major and minor streams are subject to periodic stream flooding (units Qa, Qac, Qf, and, locally Qw). Relatively gently inclined slopes in areas away from streams, or adjacent to but above streams, locally may be susceptible to sheet flooding due to unconfined overland flow (locally in units Qf and Qac). Inundation by debris flows and hyperconcentrated flows is common on fan deposits (unit Qf) near modern stream level downslope of steep drainage basins, such as in the valley of Chalk Creek (Coe and others, 2010). Locally, debris flows form by ground saturation due to rapid snowmelt or intense and (or) prolonged rainfall that infiltrates and remobilizes preexisting, unstable landslide deposits (unit QIs), or are formed by surface runoff that erodes and entrains sediments on hillslopes and, locally, in stream channels (for example, Cannon and others, 2001). Older fan deposits that are deeply incised by modern streams (unit Qfo) commonly are not susceptible to inundation by debris flows and hyperconcentrated flows.

Surficial deposits and bedrock that underlie moderate to steep slopes are locally subject to mass-movement processes such as creep and landsliding. Fractured bedrock that underlies steep slopes is subject locally to rockfall and rockslide that locally forms talus deposits (Qt) and rock-glacier deposits (Qr). Many of the bedrock units that are commonly prone to mass-movement process (1) are poorly consolidated units that have relatively low shear strength (such as the Dry Union Formation, unit Nd) or (2) are well consolidated units with relatively high shear strength, but well developed planes of weakness associated with shale beds (such as those in the Belden Formation, $\mathrm{Pb}$ ). Some bedrock units that commonly form stable slopes may locally be prone to mass-movement processes because they have planes of weakness owing to prominent bedding planes or close-spaced joints, fractures, or fault planes. 


\section{Mineral Deposits}

The various mining districts of the upper Arkansas River region lie along the northeast-trending Colorado mineral belt, a zone of Late Cretaceous to middle Tertiary magmatism and associated mineralization that extends from southwestern Colorado to the Colorado Piedmont near Boulder. This mineral belt has an ancestry that extends back to the Proterozoic (Tweto and Sims, 1963) and contains most of the major metallic mining districts in Colorado, including the world-class lead-zinc-silver deposits of the Leadville district in the map area. Mines and prospects are scattered throughout the Sawatch and Mosquito Ranges, and this report makes no attempt to describe all the mineral deposits in detail.

\section{Leadville Mining District}

The world-class ore deposits of the Leadville district, just east of Leadville, have been extensively studied (for example, Emmons and others, 1886; Emmons and Irving, 1907; Emmons and others, 1927; Behre, 1953; Tweto, 1968; Thompson and Arehart, 1990; Wallace, 1993; Cappa and Bartos, 2007); the colorful mining history of the Leadville District is described by Cappa and Bartos (2007). Primary sulfide deposits formed at about $39.6 \pm 1.7 \mathrm{Ma}$ (Thompson and Arehart, 1990), at a depth of $\sim 5 \mathrm{~km}$ by ascending hydrothermal fluids that replaced Paleozoic carbonate rocks (mostly dolomitic Leadville Limestone [or Dolomite], but also to a lesser extent Dyer Dolomite and Manitou Dolomite) with blanket-like (manto) deposits of massive sulfides (mostly argentiferous galena and sphalerite). During the early 1860 s, native gold was a major constituent of the district's mineral production. In fact, according to Henderson (1926), the first economic discovery in late 1859 was placer gold at the mouth of California Gulch, about $4 \mathrm{~km}$ southwest of Leadville, which caused an almost immediate gold rush to the district (Parker, 1974a). Placer gold deposits in the upper part of California Gulch were some of the richest in Colorado; however, by 1874 these deposits had been extensively mined and there was little placer mining left in the gulch (Henderson, 1926). A popular but questionable story is that blue-black sand that choked sluice boxes in the Leadville district and plagued the early placer miners was later identified as argentiferous lead carbonates. Analyses of these carbonates in about 1875 indicated that they contained about $1.4 \mathrm{~kg}$ of silver per metric ton (about 40 troy ounces per short ton; Scott, 2004). The first lode deposit of silver-bearing lead carbonate was located in 1874 . The rich ore bodies on Fryer Hill, just east of Leadville, were discovered in 1878. A number of rich mines also surround the Breece Hill intrusive center (see fig. 2) (composed mostly of Johnson Gulch Porphyry; unit Pegj) about $3 \mathrm{~km}$ east of Leadville (Cappa and Bartos, 2007). The mines at Freyer Hill and Breece Hill produced a considerable amount of silver. Early smelters used charcoal, but smelting of ore really got underway after the first railroads arrived in 1880, carrying coal.
The early lode mining exploited oxidized ores (lead-zinc carbonates) until the deeper sulfide ores were encountered. The primary control on mineralization was an impervious layer, such as shale, quartzite, or porphyry, overlying a carbonate rock. Mineralized fluids ascended along faults, which are also locally mineralized. The source for the fluids is apparently a deep, unexposed 40 Ma magma body. Exposed porphyries are essentially unmineralized, although many of them, particularly the Johnson Gulch Porphyry, were emplaced at approximately the same time as was mineralization.

In all, the Leadville mining district produced more than 1.8 billion dollars' worth of silver, lead, zinc, gold, and copper (at then-current prices; Cappa and Bartos, 2007); the first three metals named accounted for 95 percent of the value. Manganese, bismuth, and sulfuric acid from pyrite were also produced as byproducts. Mining continued more or less continually until the last operating mine, the Black Cloud Mine operated by Asarco Grupo Mexico, closed in 1999.

\section{Western Alma Mining District}

The principal mine of the western part of the Alma mining district is the London Mine (Singwald and Butler, 1941), about $13 \mathrm{~km}$ northeast of Leadville. The mine consists of a northern and southern part, connected by a tunnel under London Mountain. It produced a significant amount of gold and was in operation until 1989. The London Mine hosted the first aerial tramway constructed in Colorado. The ores all lie within several hundred meters of the London fault and consist of three ore types (1) gold-bearing quartz-sulfide veins roughly parallel to the London fault, within or near sills that are close to the base of the Minturn Formation ( $\mathbb{P m}),(2)$ replacement silver-lead sulfide ores principally within the Leadville Limestone (or Dolomite; MI), similar to those in the Leadville district, and (3) gold deposits in the Sawatch Quartzite.

\section{Two Bits and Granite Mining Districts}

In the 1860 s, gold-bearing quartz-pyrite veins cutting Paleoproterozoic migmatitic biotite gneiss $(\mathrm{Xb})$ and Mesoproterozoic granitic rocks were discovered on the east side of the Arkansas River, about $14 \mathrm{~km}$ south of Leadville (Hedlund and others, 1983; Cappa and Bartos, 2007). The veins mostly trend east-northeast, roughly parallel to regional foliation in the Proterozoic rocks. The veins are oxidized to a depth of about $65 \mathrm{~m}$. About 75,000 ounces (oz) of gold and a subordinate amount of silver were produced in the district. Laramide-age rhyolite and dacite dikes are associated with some of the gold-bearing veins and may have played a role in mineralization (Cappa and Bartos, 2007); an east-trending rhyolite dike has a K-Ar age of $65.3 \pm 2.4 \mathrm{Ma}$ (Marvin and others, 1989). The two largest mines were the Belle of Granite and Yankee Blade Mines; the Two Bits Mine along Twobit Gulch is several km north of the main district and mainly produced silver. 


\section{Placer Gold Mining Areas Near Granite and Balltown}

Placer gold was discovered in surficial deposits along Cache Creek in 1859 (Henderson, 1926) or 1860 (Emmons and others, 1886), about $22 \mathrm{~km}$ south of Leadville. More placer deposits were soon discovered in other areas west and north of Cache Creek. Between about 1860 and 1959, the three main placer mining areas (Cache Creek, Lake Creek, and Corske Creek) produced at least 2,555,000 dollars (at time of production) worth of placer gold, ranking them among the richest placer mining areas in Colorado (Shroba and others, 2014). In these areas, gold was first produced by hand methods and ground sluicing (between about 1860-1883), and later by hydraulic mining, dredging, and dragline (between about 1884-1950) after the arrival of heavy equipment and water diverted from the Clear Creek drainage (Parker, 1974a, 1974b). The main sources of placer gold in these areas are outwash gravel of the Pinedale glaciation (Qgp) and fluvial gravel in the Dry Union Formation (Nd). The gold in these deposits probably was derived chiefly from gold-bearing veins in the bedrock in the Sawatch Range near the head of Lost Canyon and in the Lake Creek drainage (Howell, 1919; Gese and Scott, 1993; Cappa and Bartos, 2007). Minor amounts of placer gold are still being produced by present-day recreational prospectors from deposits along Cache Creek and Lake Creek previously worked by miners about a century ago.

\section{Weston Pass Mining District}

The small Weston Pass district lies on Weston Pass at an elevation of about $3,660 \mathrm{~m}(12,000 \mathrm{ft})$, about $16 \mathrm{~km}$ southeast of Leadville. The replacement ore is confined to a well-defined stratigraphic horizon in the dolomitic Leadville Limestone, which is anomalously thick there (about $112 \mathrm{~m}$ ), probably due to reverse or thrust faulting along a splay of the Weston fault (Behre, 1932). The primary ore consists of argentiferous galena, lesser amounts of sphalerite, and gold-bearing pyrite; significant oxidation of the ore to lead-zinc-iron carbonates occurs near the surface. The ore zone is about $25 \mathrm{~m}$ above a prominent brecciated jasperoid zone in the Leadville Limestone, probably the trace of the formation-thickening reverse fault. The Ruby Mine was the largest in the district, producing mostly lead and a limited amount of zinc, silver, and gold (Behre, 1932).

\section{Twin Lakes Mining District}

Northeast-striking, northwest-dipping, gold-bearing quartz veins occur along faults that cut the northeastern margin of the 64-Ma Twin Lakes Granodiorite (PEtlg) batholith and adjacent biotite-sillimanite schist and gneiss, about $20 \mathrm{~km}$ southwest of Leadville. Beginning in 1884, gold-bearing quartz veins were mined about $3 \mathrm{~km}$ northwest of the small town of Twin Lakes, where the principal producer was the Gordon Mine, which operated until World War II (Cappa and Bartos, 2007). Gold was the primary commodity mined, although significant quantities of silver, lead, zinc, and copper were also produced.

\section{Sugar Loaf and St. Kevin Mining Districts}

The Sugar Loaf and St. Kevin districts, about $9 \mathrm{~km}$ west of Leadville (just south and north of Turquoise Lake, respectively), are parts of the same mineralized system that produced mostly silver and subordinate gold from the 1880s until just after World War II. The combined output from these two districts is estimated to be $10,000,000$ to $15,000,000$ dollars (at time of production) worth of ore. The Dinero Mine was by far the most productive mine in the Sugar Loaf district. It produced about $1,000,000$ dollars and, perhaps, as much as 2,000,000 dollars (at time of production) worth of ore. The St. Kevin Mine was one of the most productive mines in the St. Kevin district. It may have produced as much as 1,000,000 dollars (at time of production) worth of ore (Singewald, 1955). Mineralization is along north-striking veins (more properly described as a broad shear zone) cutting Mesoproterozoic granite (mostly St. Kevin Granite; Ygs) and Paleoproterozoic biotite gneiss and schist. East-striking, strongly silicified felsite porphyry dikes cut the combined districts.

\section{Mount Antero Mining District}

Gem-quality aquamarine (blue beryl, the Colorado State gemstone), formed in bedrock on the slopes of Mount Antero and Mount White, about $21 \mathrm{~km}$ southwest of Buena Vista, has long been prized by gem collectors. The mineral, along with the beryllium minerals phenakite and bertrandite, formed in cavities within pegmatites and quartz veins in the Mount Antero and California leucogranite intrusions (units $\mathrm{P}$ ag and $\mathrm{PEcg}$, respectively) (Adams, 1953; Sharp, 1976). Blue, clear, and yellow varieties of beryl have been identified. The California Mine, along a dike of the leucogranite of the California Mine (PEcg) at the head of Browns Creek, was first mined as a molybdenum prospect (Worcester, 1919). The ore contains beryl and molybdenite in north-northeast-striking quartz veins.

\section{Garfield Mining District}

Several mines and prospects along Taylor Gulch, north of the small town of Garfield (near western boundary of the map area), produced silver, copper, lead, zinc, and gold from replacement deposits in the Manitou Dolomite (Om; Dings and Robinson, 1957). The Garfield mining district is only partially within the map area and extends just to the west of the map boundary. It is part of the more extensive GarfieldMonarch mining district of Dings and Robinson (1957). Much of the ore was from oxidized zones above the primary sulfide zone. The principal mines are the Lily and Garfield. An aerial tramway carried ore from the Lily Mine to Garfield. The mines operated from the late 1880s until several years after the end of World War II. 


\section{Sedalia Copper-Zinc Mining District}

The Sedalia Mine, about $5 \mathrm{~km}$ north of Salida, exploited a horizon in actinolite-chlorite-mica schist adjacent to a metagabbro dike. This horizon contained sphalerite, chalcopyrite, and minor galena variably oxidized to carbonate minerals (Van Alstine, 1974); most production, from about 2,500 $\mathrm{m}$ of drifts and crosscuts, was from oxidized ore. Copper and zinc, with some silver, gold, and lead were mined from 1881 until 1923. At one time, the Sedalia Mine was the largest copper mine in Colorado (Van Alstine, 1974).

\section{Browns Canyon Fluorspar Mining District}

The Browns Canyon fluorspar mining district is one of the major fluorspar districts in the United States (Van Alstine and Cox, 1969). The fluorspar consists of fine-grained sugary masses in breccia zones along a large normal fault that forms the west side of the Browns Canyon horst in the USGS Nathrop and Salida West 7.5' quadrangles, about $13 \mathrm{~km}$ northwest of Salida. The fault juxtaposes Proterozoic gneiss and granitic rocks against Oligocene Wall Mountain Tuff (PEwm). The fluorite is an epithermal deposit formed by hot springs, probably during late Oligocene or Miocene time, contemporaneous with normal faulting. Mining began about 1923 and continued until 1949; in all, about 130,000 short tons of fluorspar concentrate were recovered. Much of the fluorspar concentrate produced by mining district came for the Colorado-American Mine (Van Alstine and Cox, 1969).

\section{Sand and Gravel Resources}

Alluvial deposits of late Pleistocene and Holocene age along major streams within the map area contain abundant deposits of sand and gravel suitable for concrete aggregate and other construction materials. The best sources of these deposits are outwash gravel of the Pinedale glaciation (Qgp) along the Arkansas River, South Arkansas River, South Fork South Platte River, and their major tributary streams that head in glaciated valleys. This outwash gravel commonly contains only minor amounts of fine-grained sediment, weathered clasts, or secondary calcium carbonate. Deposits proximal to till of the Pinedale glaciation (Qtp) are bouldery and may be difficult to excavate and process. Other sources of sand and gravel include deposits of older glacial outwash (prePinedale), young stream-channel and overbank alluvium (Qa), placer-tailings deposits (pt), and flood gravel and channel deposits of the Pinedale glaciation (Qpf and Qpfo). Factors such as significant amounts of weathered clasts and secondary calcium carbonate, thick deposits of fine-grained overbank sediments, high-water table conditions and periodic flooding, and abundant coarse cobbles and boulders commonly or locally render these latter deposits less suitable than those of outwash gravel of the Pinedale glaciation (Qgp). 


\section{DESCRIPTION OF MAP UNITS}

\section{SURFICIAL DEPOSITS}

As used in this report, the terms "stream alluvium" and "fluvial deposits" refer to sediment transported by running water confined to channels, whereas the terms "sheetwash alluvium" and "sheetflood alluvium" refer to sediment transported by running water not confined to channels. The terms "colluvium" and "mass-movement deposits" refer to rock and sediment transported downslope chiefly by gravity. Map units that include debris-flow deposits, such as some of the surficial map units in the map area, probably also include hyperconcentrated-flow deposits. These latter deposits have bedding and sorting characteristics intermediate between those of stream-flow and debris-flow deposits.

In descriptions of surficial deposits, the term "clasts" refers to granules and larger particles ( $>2$ millimeter $[\mathrm{mm}]$ in diameter), while the term "matrix" refers to sand and finer particles ( $\leq 2 \mathrm{~mm}$ in diameter). The terms "soil" and "soils", used in this report, refer to pedogenic soils formed in surficial deposits. Soil-horizon designations are those of the Soil Survey Staff (1999) and Birkeland (1999). All colors for soil horizons, sediments, and bedrock in this report are informal field designations.

\section{ANTHROPOGENIC DEPOSITS}

af

pt

$\mathrm{mw}$

SS

Qa

Qgp

Artificial-fill deposits (latest Holocene) - Unit consists of two types of engineered, compacted fill material: (1) small boulders to granules, sand, and silt that is armored by about 1-m-diameter rock fragments (rip-rap material) that form the dams for the Mount Elbert Forebay and the Twin Lakes and Clear Creek Reservoirs, and (2) mostly sand, silt, and rock fragments placed beneath the runways at airports near Leadville and Buena Vista. Estimated thickness is 1-30 m

Placer-tailings deposits (latest Holocene) - Chiefly sand, pebbles, cobbles, and boulders in hummocky deposits formed by hydraulic mining, dredging, and dragline operations, and locally by hand methods, that concentrated native gold. Some of the largest deposits are the dredge and dragline tailings along the lower reaches of Corske, Herrington, and Box Creeks and the hydraulic mining deposits along Cache Creek in the USGS Granite 7.5' quadrangle (Shroba and others, 2014). Estimated thickness is 1-10 m

Mine-waste deposits (latest Holocene)—Fine- to coarse-grained rock fragments in piles adjacent to and derived from subsurface mine workings. Estimated thickness is 1-10 m

Smelter-slag deposits (latest Holocene) - Black, stony, waste product formed during the processing of metallic ore at the sites of former smelters in the lower reach of California Gulch near Leadville. Estimated thickness 1-10 m

\section{ALLUVIAL DEPOSITS}

Young stream-channel and overbank alluvium (Holocene) - Mostly pebbly sand and poorly sorted, clast-supported, pebble, cobble, and, locally, bouldery gravel in a sandy matrix. Unit locally may include thin, organic-rich layers. Clasts commonly are subangular and subrounded and consist of Proterozoic igneous and metamorphic rocks, Cretaceous and Tertiary intrusive rocks, and, in Arkansas River channel, Paleozoic sedimentary rocks (mostly Cambrian quartzite). Deposits form streambeds and adjacent flood plains, fill channels, and underlie low terraces less than about $2 \mathrm{~m}$ above present stream level. Low-lying areas are prone to periodic erosion and (or) deposition. Locally includes minor amounts of colluvium (Qc) and small fan deposits (Qf); locally may include outwash gravel of Pinedale glaciation (Qgp). Estimated thickness is 5-10 m Outwash gravel of Pinedale glaciation (late Pleistocene) - Glaciofluvial deposits composed chiefly of clast-supported, poorly sorted, and crudely stratified, coarse pebble and cobble gravel deposited by glacial meltwater streams during the Pinedale glaciation. Unit locally includes layers and lenses of sandy pebble gravel and pebbly sand. Top of gravelly deposits are locally overlain by about $30-50 \mathrm{~cm}$ of overbank sediment that is commonly composed of pebbly sand (Nelson and Shroba, 1998). Commonly, deposits proximal to till of Pinedale age (Qtp) are bouldery and locally contain boulders 
as large as $1.5 \mathrm{~m}$ in diameter. Soils formed in unit Qgp have cambic B (Bw) or weakly developed argillic B (Btj and Bt) horizons about $30 \mathrm{~cm}$ thick (Nelson and Shroba, 1998). The exposed portions of most surface boulders of granitic composition show little evidence of weathering (Shroba and others, 2014). The sources of unit Qgp are glaciers that deposited till of Pinedale glaciation (Qtp) within and just beyond the mouths of glaciated valleys in the Sawatch Range and Mosquito Range. Gravel along course of Arkansas River commonly consists of Proterozoic granitic and gneissic clasts, a high percentage of Tertiary intrusive rocks, and Paleozoic quartzite. Southeast of the confluence with the South Arkansas River, deposits of unit Qgp along the Arkansas River locally contain large boulders, deposited by glacial-breakout floods during the Pinedale glaciation. These boulders are similar in size and composition to those in units Qpf and Qpfo. Deposits of unit Qgp, in the valley of Lake Creek near the Twin Lakes Reservoir and in the valley of Clear Creek near the Clear Creek Reservoir, are graded to and are coeval with till of unit Qtp, which dates from about 15-22 ka (Young and others, 2011). Unit Qgp along Lake Creek near Balltown locally contains boulders as large as about $2.7 \times 3.0 \times 3.0 \mathrm{~m}$ that probably were deposited during one or more glacial outburst floods initiated by the rapid drainage of a lake or lakes impounded by glacial ice or moraines of unit Qtp in the vicinity of the Twin Lakes dam (Shroba and others, 2014). Deposits of unit Qgp locally underlie two or more terrace levels about 2-10 m above South Arkansas River near Maysville and Poncha Springs, the Arkansas River north of Riverside (table 1), and the South Fork South Platte River near the eastern boundary of the map area. Estimated thickness is 3-20 m Flood gravel consists of very crudely stratified, extremely coarse, boulder gravel in a yellowish-gray to gray, cobble, pebble, and sand matrix deposited in the valley of Arkansas River downstream of Clear Creek. Boulders are as long as about $10 \mathrm{~m}$ (figs. $7 A$ and $7 B$ ). These exceptionally large, outsized clasts or "megaclasts" are interpreted as traction bed load that was deposited during one or more catastrophic releases of impounded glacial meltwater resulting from the failure of a glacial dam at Clear Creek and possibly one at Pine Creek (Lee, 2010). Clasts are composed almost entirely of Proterozoic granitic and gneissic rocks. ${ }^{10} \mathrm{Be}$ surface-exposure ages of four large flood boulders on deposits of unit Qpf indicate a mean age of $17.8 \pm 0.5 \mathrm{ka}$ (Young and others, 2011) for the failure and breaching of glacial dam(s) and the deposition of the flood gravel. Flood gravel locally forms large bars about 5-8 $\mathrm{m}$ above present level of Arkansas River (fig. 7). Associated channel deposits inset into the flood gravel, some too small to show at map scale, consist chiefly of sand and granule- to cobble-size clasts deposited in channels and swales cut into the flood gravel. Flood boulders in the channel deposits are rare or absent. Channel deposits mark the former courses of the Arkansas River during the waning phase or slightly after the younger flood of the Pinedale glaciation. Unit Qpf locally may include deposits of outwash gravel of Pinedale glaciation (Qgp) that postdates deposition of unit Qpf and older flood gravel and channel deposits of Pinedale glaciation Qpfo. Top of unit Qpf is as much as about $9 \mathrm{~m}$ above the Arkansas River downstream of glacial dam on Clear Creek (table 1). Estimated thickness of floodgravel deposits is $>20 \mathrm{~m}$ near the source of the flood and thinner downstream; estimated thickness of associated channel deposits is as much as $2 \mathrm{~m}$ gravel consists of very crudely stratified, extremely coarse, boulder gravel in a gray to yellowish-gray, cobble, pebble, and sand matrix deposited in valley of Arkansas River downstream of Pine Creek. Boulders are as long as $15 \mathrm{~m}$. These exceptionally large outsized clasts or "megaclasts" are interpreted as traction bed load that was deposited during one or more catastrophic releases of impounded glacial meltwater resulting from the failure and breaching of a glacial dam at Clear Creek and possibly one at Pine Creek (Lee, 2010). ${ }^{10} \mathrm{Be}$ surface-exposure ages of four large flood boulders on deposits of unit Qpfo indicate a mean age of $19.6 \pm 0.6 \mathrm{ka}$ (Young and others, 2011) for the failure and breaching of glacial dam(s) and the deposition of the flood gravel. Previously interpreted as flood gravel of Bull Lake age by Lee (2010). Flood gravel forms large 
Table 1. Approximate height, in meters, of the top of gravelly stream alluvium of Pleistocene or Pliocene age above the Arkansas River.

[-, no deposits or deposits too small to show at map scale]

\begin{tabular}{cccccccc}
\hline $\begin{array}{c}\text { Map } \\
\text { unit }\end{array}$ & Leadville & Balltown & Riverside & $\begin{array}{c}\text { Buena } \\
\text { Vista }\end{array}$ & Nathrop & $\begin{array}{c}\text { Mouth of } \\
\text { Browns Canyon }\end{array}$ & Smeltertown \\
\hline Qgp & $2-10$ & $2-10$ & - & - & - & - & - \\
\hline Qpf & - & - & $3-9$ & 10 & 10 & 10 & 10 \\
\hline Qpfo & - & - & $10-20$ & $15-20$ & $15-20$ & - & - \\
\hline Qgb & 35 & 40 & - & 40 & 35 & - & 25 \\
\hline Qg4 & - & - & - & - & - & - & - \\
\hline Qpb & - & - & 60 & - & - & - & - \\
\hline Qg3 & 70 & 70 & 60 & 45 & - & - & - \\
\hline Qg2 & 120 & 100 & 70 & 70 & 80 & 85 & - \\
\hline Qg1 & 135 & - & 80 & 100 & 110 & - & - \\
\hline QNg & 150 & - & - & - & - & - & - \\
\hline
\end{tabular}

$\boldsymbol{A}$
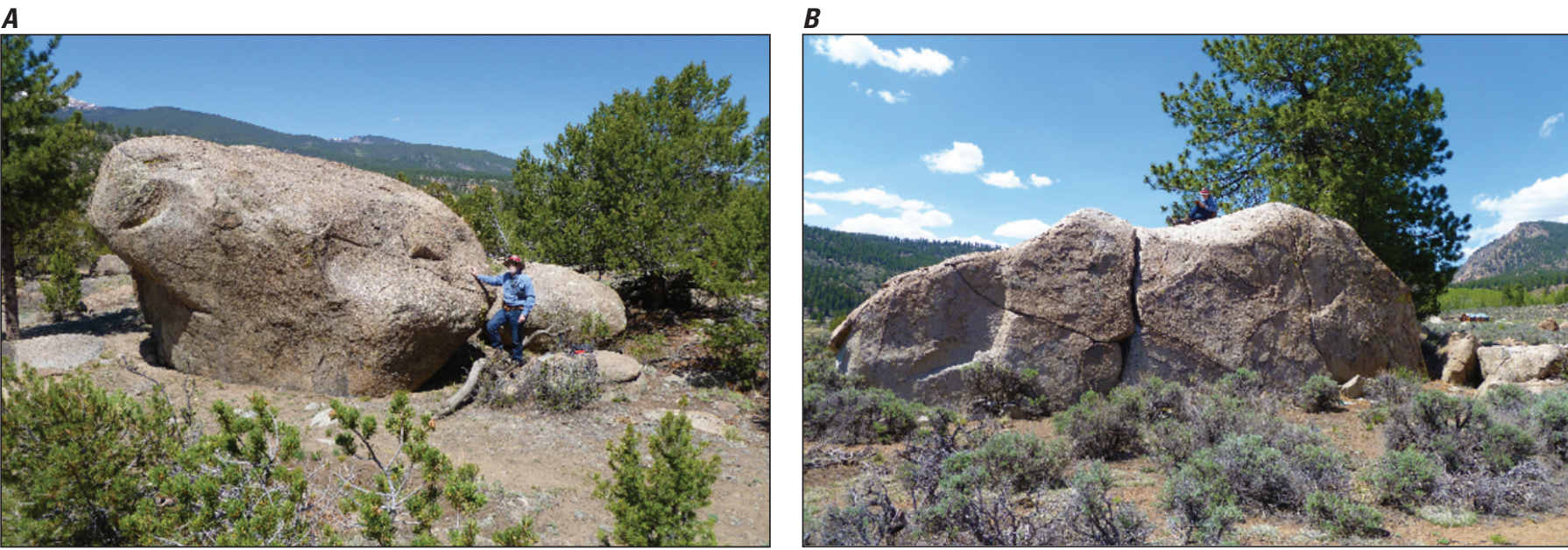

Figure 7. A, View north of enormous granitic flood boulder on Qpf terrace deposits (Harvard Lakes 7.5' quadrangle; Kellogg and others, 2013). Boulder measures about $8 x 6 x>4 \mathrm{~m}$. $B$, View north of largest known flood boulder in the upper Arkansas River valley, on terrace surface underlain by unit Qpfo shown in fig. 8. Boulder measures 14x5x>5 m. Note person on boulder for scale. Photographs by Karl $S$. Kellogg, July 2011.

bars about 10-20 m above present level of Arkansas River (table 1; fig. 8), and about 7-11 m above level of younger flood gravel and channel deposits of Pinedale glaciation (Qpf). Typically, flood boulders in flood gravel are stacked upon each other. The largest observed flood boulder measures $5 \times>5 \times 14 \mathrm{~m}$ (fig. $7 B$ ). Associated channel deposits inset into the flood gravel, some too small to show at map scale, consist chiefly of sand and granule- to boulder-size clasts deposited in channels and swales cut into the flood gravel. The difference in elevation between the top of the flood gravel of unit Qpfo and the top of the younger flood gravel unit Qpf (about 7-11 m), suggests a considerable amount of erosion and down cutting over a period of about 1,800 years. Unit Qpfo locally may include deposits of younger flood gravel and channel deposits of Pinedale glaciation Qpf. Top of unit Qpfo is as much as about 20 m above the Arkansas River downstream of Pine Creek (table 1). Estimated thickness of flood-gravel deposits is $>20 \mathrm{~m}$ near the source of the flood, but appear to thin to about $5 \mathrm{~m}$ near Elephant Rock, just north of Buena Vista where it overlies Dry Union Formation (Nd); estimated thickness of associated channel deposits is as much as $2 \mathrm{~m}$ 


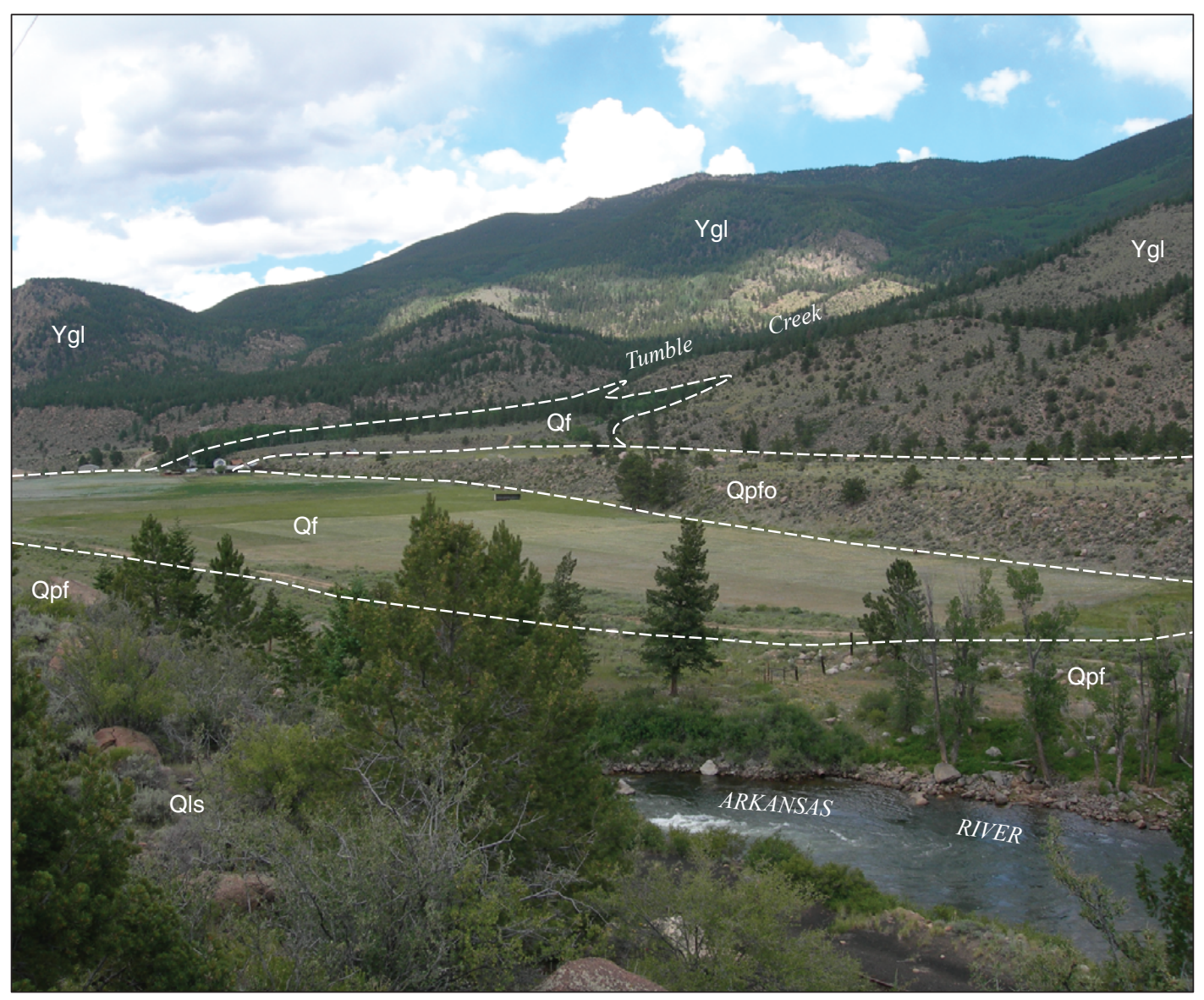

Figure 8. View northeast from Highway 24 of terraces along the Arkansas River about $4 \mathrm{~km}$ northwest of Riverside. Qf is a fan deposit. Lower terrace near the river is underlain by younger Pinedale-age flood deposit (Qpf). Higher terrace in the background is underlain by older Pinedale-age flood deposit (Qpfo), with visible large flood-transported boulders, some longer than $5 \mathrm{~m}$. Both of these flood deposits are locally mantled by fan deposits (Qf) that issued from the Tumble Creek drainage (backgound on left side of photo). Most of the mountainous area in the image is underlain by Langhoff Gulch Granite (Ygl). Dashed lines indicate the contacts between the units. Photograph by Karl S. Kellogg, July 2011. by glacial meltwater streams during the Bull Lake glaciation. Unit locally includes layers and lenses of sandy pebble gravel and pebbly sand. Top of gravelly deposits are locally overlain by about $20-30 \mathrm{~cm}$ of overbank sediment composed of pebbly sand (Nelson and Shroba, 1998). Deposits proximal to till of Bull Lake age (Qtb) are bouldery and locally contain boulders as large as $1.5 \mathrm{~m}$ in diameter. Soils formed in outwash of Qgb have argillic B (Bt) horizons commonly about 40-65 cm thick (Nelson and Shroba 1998; Shroba and others, 2014), and locally have Bk horizons with stage II carbonate morphology (Nelson and Shroba, 1984). Exposed portions of some surface boulders of granitic composition are extensively weathered (Shroba and others, 2014). Sources of unit Qgb are glaciers that deposited till of Bull Lake glaciation (Qtb) within and just beyond the mouths of glaciated valleys in the Sawatch Range and Mosquito Range. Unit Qgb commonly underlies two major terrace levels, which suggests two major episodes of deposition, but is mapped as one unit along Arkansas River and some of its glaciated tributary streams and along some of the glaciated tributary streams of the South Fork South Platte River. Top of unit Qgb is as much as about $40 \mathrm{~m}$ above the Arkansas River near Buena Vista, and Balltown (table 1). Estimated thickness 1-10 m 
Qgby Younger outwash gravel of Bull Lake glaciation (late and middle? Pleistocene)—Unit only mapped along the South Arkansas River where it underlies terrace surfaces about $15 \mathrm{~m}$ above stream level. Estimated thickness $1-10 \mathrm{~m}$ only mapped along the South Arkansas River where it underlies terrace surfaces about $30 \mathrm{~m}$ above stream level. Estimated thickness $1-10 \mathrm{~m}$

Outwash gravel of pre-Bull Lake age (middle and early Pleistocene)-Mostly deposits of cobbly pebble outwash gravel deposited by glacial meltwater streams during pre-Bull Lake glaciations. Locally includes gravel deposited by streams of non-glacial origin that may have been feed by periglacial debris and transported by north-flowing streams tributary to the South Arkansas River near the southern boundary of the map area. Deposits locally form alluvial plains and aprons and underlie terrace surfaces along and west of the Arkansas River, along and south of the South Arkansas River, and along the South Fork South Platte River at its confluence with Twelvemile Creek. Estimated thickness is $1-20 \mathrm{~m}$ mapped near Buena Vista, Nathrop, and Maysville by Scott (1975), Scott and others (1975), McCalpin and Shannon (2005), and Shannon and McCalpin (2006) who called it Illinoian (?) alluvium. In this report, deposits of unit Qg4 are only identified and mapped along the South Arkansas River near it confluence with the Arkansas River. Top of unit Qg4 is about $50 \mathrm{~m}$ above South Arkansas River near Poncha Springs

Gravelly stream alluvium of pre-Bull Lake age (middle Pleistocene)—Chiefly pebble and cobble gravel deposited by streams of non-glacial origin, but may locally include deposits of outwash gravel. Top of deposits commonly are 35-90 m above stream level. Deposits of unit Qapb are mapped in the following areas: (1) south side of Big Union Creek, about $11 \mathrm{~km}$ south of Leadville; (2) north side of Trout Creek, about $2 \mathrm{~km}$ east of Johnson Village; (3) south side of Ute Creek, about $1 \mathrm{~km}$ north of Salida; (4) south side of Sweetwater Gulch, about $0.5 \mathrm{~km}$ east of Salida; and (5) north side of Pole Gulch, about $24 \mathrm{~km}$ northeast of Buena Vista near the eastern boundary of the map area. Estimated thickness is $1-10 \mathrm{~m}$ Unit probably locally includes deposits of units Qg2 and Qg3, and, possibly, Qg4 mapped near Buena Vista, Nathrop, and Maysville by Scott (1975), Scott and others (1975), McCalpin and Shannon (2005), and Shannon and McCalpin (2006) who called it Kansan (?) alluvium. Deposits of unit Qg3, on the west side of the Arkansas River about $4 \mathrm{~km}$ southwest of Nathrop, are overlain by fine-grained sediment that contains water-lain 639 $\pm 2 \mathrm{ka}$ Lava Creek B ash (type O Pearlette ash of Scott and others, 1975 and Izett and Wilcox, 1982. Two other deposits of Lava Creek B ash (type O Pearlette ash of Scott, 1975), identified by Scott (1975) on the east side of the Arkansas River about $8 \mathrm{~km}$ northwest of Buena Vista near Riverside, overlie bouldery flood gravel of unit Qpbf. On the west side of the Arkansas River outwash gravel of unit Qg3 overlies, locally may be interbedded with, and locally may include flood gravel of unit Qpbf. Top of unit Qg3 is about 70 m above the South Arkansas River near Maysville and Poncha Springs and is as much as $70 \mathrm{~m}$ above the Arkansas River near Balltown and Leadville (table 1)

\section{Qpbf}

Flood gravel of pre-Bull Lake age (middle Pleistocene)—Bouldery flood gravel exposed along Arkansas River near Riverside where it is locally overlain by water-lain deposits of Lava Creek B volcanic ash (Scott, 1975), erupted ca. 640 ka (Lanphere and others, 2002) within or near Yellowstone National Park (Izett and others, 1970; Van Alstine, 1974). Near Riverside, the ash is overlain by, and preserved beneath, fan deposits (Qf). Deposits of unit Qpbf locally underlie, are locally interbedded with, and locally include outwash gravel of unit Qg3. The largest observed flood boulder on unit Qpbf is a gneissic granodiorite that measures $>2.7 \times 5.0 \times 8.2 \mathrm{~m}$ (Kellogg and others, 2013). Top of unit Qpbf is about $60 \mathrm{~m}$ above Arkansas River (table 1). Estimated thickness is $1-10 \mathrm{~m}$ 
Qg2 Outwash gravel of pre-Bull Lake age, level 2 (middle or early Pleistocene)—Unit previously mapped near Buena Vista, Nathrop, and Maysville by Scott (1975), Scott and others (1975), McCalpin and Shannon (2005), and Shannon and McCalpin (2006) who called it Nebraskan (?) alluvium. Deposits of unit Qg2, about $7 \mathrm{~km}$ southwest of Nathrop near Centerville, are overlain by fine-grained sediment that contains water-lain $739 \pm 2 \mathrm{ka}$ Bishop ash (Scott and others, 1975; Izett and others, 1988). The ash was erupted from the Long Valley caldera in eastern California (Izett and others, 1988); contains augite and hornblende phenocrysts and is about $760 \mathrm{ka}$ (SarnaWojcicki and others, 2000). Unit Qg2, about $2 \mathrm{~km}$ northwest of Balltown, locally contains boulders as large as about $\geq 1.8 \times 2.0 \times 4.2 \mathrm{~m}$ that probably were deposited by one or more glacial outburst floods, which may have originated in the Lake Creek drainage (Shroba and others, 2014). Top of unit Qg2 is about $80 \mathrm{~m}$ above the South Arkansas River near Maysville and Poncha Springs and is as much as about $120 \mathrm{~m}$ above the Arkansas River near Leadville (table 1)

Qg1 Outwash gravel of pre-Bull Lake age, level 1 (early Pleistocene)—Unit previously mapped near Buena Vista, Nathrop, and Maysville by Scott (1975), Scott and others (1975), McCalpin and Shannon (2005), and Shannon and McCalpin (2006) who called it Nussbaum (?) alluvium. Highest-level outwash gravel in map area; top of unit is about 10-30 m above that of nearby deposits of unit Qg2. Deposits of unit Qg1 south of Squaw Creek, about $12 \mathrm{~km}$ northwest of Salida, are slightly higher above stream level than those that are north of Squaw Creek and south of Browns Creek. Consequently, deposits of unit Qg1 south of Squaw Creek may be slightly older than those north of Squaw Creek. Top of unit Qg1 is about $95 \mathrm{~m}$ above the South Arkansas River near Maysville and Poncha Springs and is as much as about $135 \mathrm{~m}$ above the Arkansas River near Leadville (table 1)

QNg Very old alluvial gravel of Arkansas River (early Pleistocene? or Pliocene)—Fluvial gravel deposited by the Arkansas River and overlies the Dry Union Formation (Nd) on the east side of the Arkansas River, near the mouth of Dry Union Gulch, about $7 \mathrm{~km}$ south of Leadville (McCalpin, Funk, and others, 2012). Unit consists chiefly of angular and subrounded pebbles and cobbles of Paleozoic quartzite and carbonate rocks, fine-grained Tertiary intrusive rocks, and Proterozoic metamorphic and igneous rocks. Top of unit QNg is about $150 \mathrm{~m}$ above the Arkansas River (table 1). Thickness is about $3-15 \mathrm{~m}$

\section{GLACIAL DEPOSITS}

Rock-glacier deposits (early Holocene and latest Pleistocene?)—Bouldery, lobate and tongue-shaped masses that commonly have steep fronts and flanks along valley walls and on valley floors. Commonly formed in or near cirques or near valley heads above an elevation of about 3,350 m. Deposits consist of a veneer of angular boulders that overlie a thick mass of rock rubble containing finer interstitial rock fragments and locally interstitial ice, ice lenses, or an ice core. Rock fragments on and within rock-glacier deposits are derived from steep slopes chiefly by rockfall and locally by rockslide and avalanche. Lobate rock glaciers form along valley walls, and are icecemented. Tongue-shaped rock glaciers resemble glaciers in shape, form on valley floors, and commonly have debris-covered ice cores (Benedict, 1973a; White, 1976). Ice-cemented rock glaciers likely formed under periglacial conditions (Barsch, 1987), whereas ice-cored rock glaciers probably are debris-covered glaciers (Janke, 2007). Unit Qr locally includes minor talus deposits (Qt) displaced by post-depositional creep or flowage, colluvium (Qc), and other mass-movement deposits. Near cirque headwalls, unit Qr locally may include till(s) of Holocene age, and father down valley locally may include till of Pinedale glaciation (Qtp). Lobate rock-glacier deposits exposed at a mine in Iowa Gulch, about $7 \mathrm{~km}$ southeast of Leadville, consist of a bouldery veneer about 1-2 $\mathrm{m}$ thick that overlies rock rubble composed of about 50 percent rock fragments 5-70 $\mathrm{mm}$ in diameter in a matrix composed chiefly of granules, sand, and silt cemented by interstitial ice. The matrix locally contains ice masses as much as several 
$\mathrm{cm}$ in diameter, as well as an ice lens about $1 \mathrm{~m}$ thick (Vick, 1981). Rates of downslope movement of active rock glaciers in the map area are unknown, but they may be similar to those in the northern Front Range, northern Sawatch Range, or eastern Elk Mountains just west of the map area, which, are about 1-20 cm/yr (Outcalt and Benedict, 1965; White, 1971, 1976), 8-13 cm/yr (Miller, 1973), and 21-68 cm/yr (Bryant, 1971), respectively. Thickness in Iowa Gulch about 15-35 m (Vick, 1981); elsewhere possibly as much as $50 \mathrm{~m}$

Till (late to early Pleistocene) - Mostly non-sorted and non-stratified, subangular to subrounded boulders as long as $4 \mathrm{~m}$ to granules in a sand, silty sand, or slightly clayey, silty sand matrix deposited by glaciers within and just beyond the mouths of glaciated valleys commonly above an elevation of 2,560-2,940 $\mathrm{m}$ on the east flank of the Sawatch Range and 2,990-3,110 m on the flanks of the Mosquito Range. Matrix (sand and finer sized particles) is estimated to comprise 30-60 percent of the deposits. End moraines near the down-valley limit of glaciation may be composed, in part, of stratified drift composed chiefly of outwash sand and gravel. Clast composition reflects that of bedrock in source areas. Tills on and near the eastern flank of the Sawatch Range are rich in clasts composed chiefly of granitic rocks and gneiss derived from Paleoproterozoic crystalline bedrock, and, locally, they contain abundant igneous rocks of Tertiary age. Tills on and near the western and eastern flanks of the Mosquito Range are locally rich in clasts of sedimentary rocks of Paleozoic age. Till units locally include or are mantled by small deposits of colluvium (Qc) and other mass-movement deposits, particularly on the lower flanks of older moraines. Till units near the lower limit of glaciation locally may include deposits of glacial outwash, and locally may contain significant amounts of silt, sand, or gravel in areas where glaciers have eroded pro-glacial lacustrine sediments, outwash, or sediments of the Dry Union Formation ( $\mathrm{Nd}$ )

Till of Pinedale glaciation (late Pleistocene) - Unit commonly forms large, very bouldery, sharp-crested lateral and end moraines that have distinct hummocky surface morphology. Deposits in some areas have well expressed knob-and-kettle topography. Some of the surface boulders of granitic and gneissic composition are as large as $\geq 4.5 \times 5.5 \times 7.0 \mathrm{~m}$. Most of the biotite-rich granitic and gneissic clasts within the soil are unweathered or slightly weathered. Youngest mapped till of Pinedale glaciation within cirques or near valley heads locally may include till similar in age to that of the Satanta Peak advance of Benedict (1973b, 1985), dated at about 10-12 ka (Davis 1988). Soils formed in the top of the unit Qtp commonly have thin $(\leq 25 \mathrm{~cm})$ cambic B horizons that are poorly developed and have little or no clay accumulation. Some soils lack B horizons and have A/Cox or A/Bk profiles (Nelson and Shroba, 1998; Shroba and others, 2014). Depth of oxidation (base of Cox soil horizon) ranges from about 50 to $170 \mathrm{~cm}$. Unoxidized till is gray, whereas soil B horizons commonly are light brown. Locally, as much as 15 percent of the biotite-rich pebbles and small cobbles within soils are partly or completely disintegrated (Shroba, 1977). Locally, multiple recessional moraines of Pinedale age were formed in glaciated valleys, including Cottonwood Creek and North Cottonwood Creek. ${ }^{10}$ Be cosmogenic surface-exposure dating (average ages) of exposed boulders and pebbles on moraine crests on the south side of Pine Creek suggests two episodes of glacial advance: one at $22.0 \pm 1.4 \mathrm{ka}$ and a later advance at $15.2 \pm 0.9 \mathrm{ka}$ (Briner, 2009). Recently reported ${ }^{10} \mathrm{Be}$ cosmogenic surface-exposure ages of exposed boulders on crests of outer and inner moraines composed of till of Pinedale age (units Qtpo and Qtpy of Shroba and others, 2014, respectively) on the southeast side of the Twin Lakes Reservoir (Schweinsberg, and others, 2016) are similar to those of a possible early advance at Pine Creek (Briner, 2009). Surface-exposure ages of boulders on the outer moraines on the southeast side of the Twin Lakes Reservoir range from $21.1 \pm 0.3 \mathrm{ka}$ to $22.2 \pm 0.3 \mathrm{ka}$ and average $21.6 \pm 0.3 \mathrm{ka}$. Ages of boulders on nearby inner moraines range from $21.1 \pm 0.3 \mathrm{ka}$ to $22.2 \pm 0.3 \mathrm{ka}$ and average $21.7 \pm 0.3 \mathrm{ka}$ (Schweinsberg, and others, 2016). The surface-exposure ages reported for Pine Creek and near the Twin Lakes Reservoir are in accord with (1) radiocarbon and cosmogenic surface-exposure ages for till of Pinedale age in the Front Range region of northcentral Colorado of about 31-12 ka (Nelson and others, 1979; Madole, 1986; Benson 
and others, 2004, 2005; Ward and others, 2007; Madole, 2010); (2) retreat of Pinedale glaciers in the Front Range and San Juan Mountains, Colorado between about 19 and $12 \mathrm{ka} \mathrm{(}{ }^{10} \mathrm{Be}$ surface-exposure ages of Guido and others, 2007; Ward and others, 2007); (3) last glacial maximum in the Taylor River drainage, about $18 \mathrm{~km}$ west of map area, of about 21-16 ka (Brugger, 2007), and a "late advance" in the Taylor River drainage of about $14.5 \mathrm{ka}\left({ }^{10} \mathrm{Be}\right.$ and ${ }^{36} \mathrm{Cl}$ cosmogenic ages of Brugger, 2007); (4) ${ }^{10} \mathrm{Be}$ and ${ }^{36} \mathrm{Cl}$ surface-exposure ages of 23-16 ka for deposits of Pinedale age in type area for till of Pinedale age in Wyoming (Chadwick and others, 1997); and (5) ${ }^{10} \mathrm{Be}$ and ${ }^{3} \mathrm{He}$ surfaceexposure ages of about 18.8-13.5 ka for till of Pinedale age in the Yellowstone regions and Teton Range (Licciardi and Pierce, 2008). ${ }^{10} \mathrm{Be}$ surface-exposure ages of glacierabraded bedrock within the cirque at the head of Rock Creek, just south of Turquoise Lake, suggest that deglaciation of the northern Sawatch Range occurred by about 15-13 $\mathrm{ka}$ (Mason and others, 2011; Ruleman and others, 2013). Estimated thickness is as much as $40 \mathrm{~m}$ lateral moraines with rounded crests that are outboard of, and locally just down valley of, the lower limit of till of Pinedale glaciation (Qtp). Moraines of unit Qtb have a surface morphology that is smoother and less hummocky than that those of the Pinedale glaciation (Qtp). Surface boulders typically are less abundant on moraines of Bull Lake glaciation than on those of the Pinedale glaciation, and till of Bull Lake glaciation is more deeply weathered. Some of the surface boulders of granitic and gneissic composition are as large as $\geq 1.4 \times 3.5 \times 3.8 \mathrm{~m}$, and commonly have weathering rinds. Soils formed in the top of till of Bull Lake glaciation commonly have argillic B (Bt) horizons about $45-50 \mathrm{~cm}$ thick. These horizons are about two to three times as thick and contain about twice as much clay than cambic B horizons formed in till of Pinedale glaciation (Nelson and Shroba, 1998; Shroba and others, 2014). Many of the biotite-rich pebbles and cobbles within soils, formed in till of Bull Lake glaciation, are partly or completely disintegrated. Recent ${ }^{10} \mathrm{Be}$ cosmogenic surface-exposure dating of four, large, exposed boulders on crests of moraines composed of till of Bull Lake age (unit Qtb of Shroba and others, 2014) on the southeast side of the Twin Lakes Reservoir produced ages that range from $106 \pm 1$ ka to $140 \pm 1$ ka and average $127 \pm 1 \mathrm{ka}$ (Schweinsberg and others, 2016). These ages are in accord with those reported for deposits of Bull Lake age in other areas of the Rocky Mountains. Age of the Bull Lake glaciation in type area in Wind River Range of Wyoming is considered to be $>130 \mathrm{ka}$ to $95 \mathrm{ka}$ (Chadwick and others, 1997). More recent $\mathrm{K}-\mathrm{Ar}$ and ${ }^{230} \mathrm{Th} / \mathrm{U}$ dating of glacial deposits near West Yellowstone and Teton Range indicate that the Bull Lake glaciation probably began prior to $167 \pm 6.4 \mathrm{ka}$ (possibly $190 \mathrm{ka}$ ) and may have continued until about $122 \pm 10 \mathrm{ka}$ (Sharp and others, 2003; Pierce, 2004; Licciardi and Pierce, 2008). Recently published ${ }^{10} \mathrm{Be}$ surface-exposure ages for boulders on till of Bull Lake glaciation in the West Yellowstone glacial system yielded a mean age of $136 \pm 13 \mathrm{ka}$ and oldest ages of about 151-157 ka (Licciardi and Pierce, 2008). These studies are in general agreement with $(1){ }^{10} \mathrm{Be}$ and ${ }^{26} \mathrm{Al}$ analyses of surface boulders on moraines of the Bull Lake glaciation near Nederland, Colo., about $95 \mathrm{~km}$ northeast of map area, that yielded minimum age estimates of $101 \pm 21 \mathrm{ka}$ and $122 \pm 26 \mathrm{ka}$ (Schildgen and others, 2002), and (2) a uranium-trend age estimate of $130 \pm 40 \mathrm{ka}$ for till of Bull Lake glaciation (Shroba and others, 1983) near Allens Park, about $120 \mathrm{~km}$ northeast of map area. Thickness locally may exceed $30 \mathrm{~m}$ subdued, eroded landforms that lack morainal morphology and are commonly outboard of and, locally, just down valley of the lower limit of till of Pinedale glaciation (Qtp) or till of Bull Lake glaciation (Qtb) near the mouths of glaciated valleys. Unit Qtpb commonly consists of deeply weathered, unstratified, unsorted, bouldery deposits that locally contain boulders longer than $3 \mathrm{~m}$. Surface soil formed in till of pre-Bull Lake age near Balltown has a reddish-brown, clayey, argillic B (Bt) horizon about $90 \mathrm{~cm}$ thick that contain about twice as much clay as those formed in till of Bull Lake glaciation (Qtb). All of the biotite-rich pebbles and cobbles within surface soils are partly or 
completely disintegrated (Shroba and others, 2014). The exposed portions of many of the surface boulders of granitic composition are extensively weathered; some of them have thick, well developed weathering rinds. Some of the large deposits of unit Qtpb, such as those north and northwest of Maysville, probably locally include bouldery deposits of uncertain origin (Qd) and deposits of bouldery colluvium (Qc) that may be derived in part from coarse, bouldery deposits in the Dry Union Formation (Nd). Thickness locally may exceed $30 \mathrm{~m}$

\section{ALLUVIAL AND MASS-MOVEMENT DEPOSITS}

Qf

Qac

Qfo

Qc

Fan deposits (Holocene and late Pleistocene)-Mostly unsorted and unstratified, matrixsupported bouldery debris-flow deposits that consist of granule- to boulder-size clasts in a sandy, silty sand, or finer-grained matrix. Unit locally includes poorly to moderately well sorted, crudely stratified, clast-supported, stream-deposited sand and gravel. These mass-movement and alluvial deposits commonly form fan-shaped landforms at the mouths of small tributaries streams. Locally these deposits coalesce to form a broad, relatively gently sloping apron. Clasts are mostly subangular to subrounded; some are as long as about $2 \mathrm{~m}$, but most are much smaller. Unit Qf is commonly graded to levels at or slightly above present stream level. Depositional processes were periodically active during the Holocene, but probably were most active during Pinedale deglaciation. Surface is locally veneered by unmapped deposits of sheetwash alluvium and probably by hyperconcentrated-flow deposits. Fan deposits on the east side of the Arkansas River, in the southern part of the map area, are locally mantled by unmapped deposits of eolian sediments and alluvium undivided (Qes). An example of unit Qf near Riverside is shown in fig. 7. Estimated thickness is as much as $15 \mathrm{~m}$

Alluvium and colluvium, undivided (Holocene to middle? Pleistocene)—Deposits composed chiefly of undifferentiated sandy and gravelly stream alluvium mainly in channels, fan deposits (Qf), colluvium (Qc), and other mass-movement deposits along minor streams and on adjacent lower (toe) slopes that are commonly too small to show separately at map scale. Unit Qac probably locally includes outwash gravel of the Pinedale glaciation (Qgp). Colluvial deposits on side slopes are commonly derived from weathered bedrock and transported downslope by mass-movement processes. In the southern part of map area, thin, unmapped, loess deposits (silty eolian sediment) locally overlies unit Qc. Thickness commonly less than $10 \mathrm{~m}$

Old fan deposits (late and middle Pleistocene) —Deposit similar to those of unit Qf that commonly form fan-shaped landforms that are graded to levels higher than those of unit Qf. Clasts are commonly subangular to subrounded and locally are 1-2 m long; some clasts are longer. Estimated thickness is as much as $15 \mathrm{~m}$

\section{MASS-MOVEMENT DEPOSITS}

Colluvium (Holocene to middle? Pleistocene) —Unconsolidated to weakly consolidated, mostly non-stratified and non-sorted, dark-brown to light-gray-brown deposits that mantle surfaces that commonly underlie slopes less than about $40^{\circ}$. Clasts and finergrained sediment are transported and deposited mainly by downslope movement. Unit commonly contains angular and subangular granule- to boulder-sized clast with lithologic compositions that reflect that of bedrock and clasts in surficial deposits farther upslope. Unit includes material transported by creep, sliding, debris flow, hyperconcentrated flow, rockfall and rockslide processes. Unit locally includes minor unmapped deposits of stream-channel and sheetwash alluvium. In the southern part of the map area, unit Qc is locally overlain by thin, unmapped, loess deposits as much as $50 \mathrm{~cm}$ thick that are composed chiefly of very fine sand and silt. Unit locally includes extensive mass-movement deposits formed by periglacial processes mainly during glacial episodes (chiefly solifluction and ice wedging) in non-glaciated, alpine areas above an elevation of about 3,500 $\mathrm{m}$. The upper part of these latter deposits consists of material derived chiefly from mechanical weathering of blocks and smaller rock 
fragments and, in part, from the deposition of loess. Surface of periglacial deposits commonly exhibit patterned ground features produced by particle sorting chiefly by near-surface frost sorting and ice wedging. Kellogg and others (2013) mapped extensive periglacial deposits in high country surrounding Buffalo Peaks in the Harvard Lakes 7.5' quadrangle. Many deposits of unit Qc mapped above treeline throughout the map area probably are composed of or locally include periglacial deposits. At lower elevations, deposits of unit Qc are locally common in open meadows, sagebrush-covered areas, and aspen groves. Estimated thickness is less than $10 \mathrm{~m}$

Qt

Talus deposits (Holocene to middle? Pleistocene)—Mostly very angular and angular cobbleand boulder-sized fragments deposited chiefly by rock and snow avalanches, rock fall, rockslide, and debris flow. Where active during the Holocene, unit forms angle-of-repose slopes below steep rocky slopes or cliffs. Stony, sandy matrix is rarely exposed except locally in recently formed, steep-sided gullies. Boulders generally are as long as $2 \mathrm{~m}$, but locally may be as long as $10 \mathrm{~m}$. Unit Qt locally includes colluvium (Qc), rock-glacier deposits (Qr), and pro-talus rampart deposits. The latter consists of talus ridges that accumulated at the base of thick perennial snowpack, commonly in cirques during the Holocene. Near cirque headwalls, unit Qt locally may include till(s) of Holocene age, and father down valley locally may include till of Pinedale glaciation (Qtp). Most extensive deposits of unit Qt are commonly mapped below steep outcrops composed of (1) predominantly volcanic rock in the Buffalo Peaks area, (2) Proterozoic rocks in and near high peaks of Sawatch Range and Mosquito Range, and (3) Tertiary plutonic rocks of Mount Princeton batholith. Estimated thickness is as much as $50 \mathrm{~m}$ and unstratified debris of various sizes as well as almost intact blocks of bedrock that slid and flowed down slopes are locally common in the map area. Younger landslide deposits commonly have hummocky surface morphology and are bounded upslope by crescent-shaped headwall scarps and downslope by lobate toes. Older landslide deposits commonly lack scarps and have more muted surface morphology. Unit QIs locally includes material displaced by rotational debris slides, translational rock and debris slides, debris flows, and possibly minor earth flows (as defined by Cruden and Varnes, 1996). Some landslides in basement rocks may have formed in rock weakened by faulting and deep-seated gravitational spreading. The sizes and lithologies of the clasts and the particle sizes of the matrices of these deposits reflect those of the displaced surficial deposits and bedrock units. Some of the largest landslides and landslide deposits form on unstable slopes that are underlain by shale of the Belden Formation $(\mathbb{P b})$ and sediments of Dry Union Formation (Nd). The large landslide deposit just south of Pine Creek formed largely by the remobilization of surficial deposits, but it probably also includes the underlying sediments of the Dry Union Formation ( $\mathrm{Nd})$. The relatively fresh landslide scarps in this deposit suggests that some of the movement occurred during the Holocene. Some landslide deposits with relatively smooth topography may be as old as early Pleistocene. Estimated thickness possibly as much as $60 \mathrm{~m}$

\section{EOLIAN AND ALLUVIAL DEPOSITS}

Qes

Eolian sediments and alluvium, undivided (Holocene to middle? Pleistocene)—Lighttan and grayish-tan, mostly wind-deposited, very fine sand and silt that locally mantles fan deposits (Qf) as well as re-deposited eolian sediments. The latter consist of slightly pebbly deposits of fine and very fine sand and silt deposited as alluvium of intermittent streams on the floors of small valleys and as sheetwash alluvium on adjacent side slopes. Unit Qes also includes thin sandy and pebbly lag deposits, too thin to show at map scale, that locally overlie colluvium (Qc), bedrock, and deposits of alluvium and colluvium, undivided (Qac). Deposits of unit Qes are well vegetated and locally incised by small modern streams. They are mapped in the Salida East and Castle Rock Gulch 7.5' quadrangles (Wallace and others, 1997; Wallace and Keller, 2003) in the southeastern part of the map area, but thin, unmapped deposits of unit Qes probably are also present in adjacent quadrangles. Estimated thickness possibly as much as $5 \mathrm{~m}$ 


\title{
MASS-MOVEMENT AND (OR) GLACIAL DEPOSITS
}

\author{
Qtr \\ Qd \\ Talus and rock-glacier deposits, undivided (Holocene and late Pleistocene)_Unit \\ locally mapped in the Sawatch Range and Mosquito Range where talus deposits (Qt) \\ and rock-glacier deposits $(\mathrm{Qr})$ are too small to show separately at map scale. Estimated \\ thickness is as much as $50 \mathrm{~m}$ \\ Diamicton (Pleistocene) - Bouldery deposits of uncertain origin that commonly lack distinct \\ depositional surface morphology and appear to be unsorted, unstratified, and contain a \\ wide range of particle sizes. Locally in areas near the lower limit of glaciation (about \\ 2,500-3,000 m), unit Qd may be composed of till of Bull Lake glaciation (Qtb) or till of \\ pre-Bull Lake age (Qtpb). In areas well above or well below the lower limit of glaciation, \\ unit $\mathrm{Qd}$ is likely to be composed of debris-flow or other mass-movement deposits. \\ Bouldery deposits in the map area, that are likely to be mass-movement deposits, are \\ commonly mapped as colluvium (Qc). Thickness unknown; possibly as much as $50 \mathrm{~m}$
}

\section{WETLAND DEPOSITS}

Qw

Qp
Wetland deposits (Holocene and late Pleistocene) - Commonly dark-brown to black, organic-rich sediment (mostly sand and finer sediment) in areas of standing water that typically support a variety of grasses, sedges, and dense stands of willows. Commonly mapped in low-gradient, high mountain valleys east and west of Arkansas River and locally in closed depressions on till of Pinedale glaciation (Qtp) as well as on younger landslide deposits (Qls). Thickness unknown; possibly as much as $5 \mathrm{~m}$

Peat deposits (Holocene and late Pleistocene) - Dark-brown peat accumulated in a grassy wetland area along a 5-km-long reach of Gas Creek, about $4 \mathrm{~km}$ south of Nathrop. The peat is partly decomposed organic matter that commonly lacks interbedded sediments and large woody fragments. Deposits contain vertebrate remains (Equus sp., Bison sp.) and pollen of pine, spruce, oak, grasses, and other species that indicate Holocene and (or) late Pleistocene age (Van Alstine and Cox, 1969). Unit was locally excavated and used as a soil additive. Exposed thickness is as much as $3 \mathrm{~m}$

\section{BASIN-FILL DEPOSITS}

Dry Union Formation (lower Pliocene? and Miocene)_Locally tan or orange-brown, gray, reddish-gray, or greenish-gray mostly unconsolidated to moderately consolidated, weakly to well stratified, locally cross-stratified, minor clay and silt, silty sand, sand, and gravel. Clasts composed mostly of Proterozoic gneiss and igneous rocks and Tertiary volcanic rocks, generally less than $10 \mathrm{~cm}$ in diameter, but locally much larger. Unit locally contains ash-rich sandstone beds. A detailed sedimentological study of the Dry Union formation in the southern part of the upper Arkansas River valley was carried out by Xu (2001). Commonly, unit is poorly exposed and is mantled by unmapped deposits of colluvium (Qc) and other mass-movement deposits and, locally, by sheetwash alluvium. Named for exposures in Dry Union Gulch, about 7 km south of Leadville (Tweto, 1961). Originally called "lake beds" by early miners that excavated shafts and adits in western part of the Leadville mining district (Emmons and others, 1886; Emmons and Irving, 1907; Emmons and others, 1927). Extensively exposed in southern part of upper Arkansas River valley; but in the northern part is mostly overlain by Quaternary surficial deposits. Generally dips gently west due to general down-dropping of west side of valley along faults. Unit $\mathrm{Nd}$ includes reddish-brown to yellowish brown, crudely bedded to well-stratified, cobbly pebble, fluvial gravel that commonly contains quartzite clasts beneath terrace deposits composed of outwash gravel of middle Pleistocene age (Qg3) between Malta and Iowa Gulch in the Leadville South 7.5' quadrangle (McCalpin, Funk, and others, 2012), where it is correlative with the Malta Gravel of Tweto (1961), but here interpreted as upper part of the Dry Union Formation. Thickness probably locally more than 1,600 $\mathrm{m}$ in southern part of upper Arkansas River valley (Tweto, 1979a) and possibly as much as 1,200 $\mathrm{m}$ in the northern part (Tweto and Case, 1972). Chiefly fluvial deposits and fan deposits are recognized in 
the northern part of the Arkansas River graben in the Granite 7.5' quadrangle. The fan deposits locally include alluvium of minor tributary streams, sheetflood deposits, and debris-flow deposits (Shroba and others, 2014). Two distinct facies (northern and southern) are recognized in the southern sub-basin of the Arkansas River graben (Shannon and McCalpin, 2006). North of the Salida-Maysville fault system (see fig. 1), the Dry Union Formation commonly consists of white, pinkish-white, orange-tan, and light greenishgray, very fine-grained siltstone, minor sandstone, and thin, discontinuous lenses of pebble to boulder conglomerate. Clasts are as long as $2 \mathrm{~m}$ (Shannon and McCalpin, 2006). Beds are as thick as several meters. Unit Nd locally forms extensive eroded, badland topography. This northern facies contains white, fine-grained, massive ash beds as much as about $1 \mathrm{~m}$ thick that are mapped at a few localities (fig. 9). Ash beds were sampled at two localities about 1.0-1.5 km south of Salida (locations A and B, table 2), yielding ages

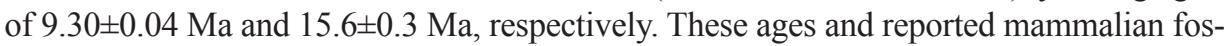
sils ages (using the current subdivision of Neogene time [U.S. Geological Survey, 2010]), the ages of ash- and fossil-bearing beds is inferred to be late Miocene or possibly early Pliocene (Van Alstine, 1974; Shannon and McCalpin, 2006). In addition to very finegrained siltstone, conglomerate, and minor sandstone, two distinct subfacies are identified south of the Salida-Maysville fault: clay subfacies (Ndc) and slide-block subfacies (Nds). South of Salida-Maysville fault, age of exposed beds may be slightly older than north of the fault, consistent with the down-to-the-north offset on the fault; ash beds in the clay subfacies (Ndc) south of the fault (described below) suggest middle Miocene age. Conglomerate clasts south of the fault typically are much larger than clasts north of the fault. Some clasts south of the fault are as large as $6 \mathrm{~m}$ (Shannon and McCalpin, 2006)

Nda Volcanic-ash beds (late Pliocene? and Miocene) - White, fine-grained, ash deposits, massive to stratified, locally fissile, mapped at a few localities mentioned above, both north and south of the Maysville-Salida fault. Individual beds possibly as much as $1 \mathrm{~m}$ thick (Shannon and McCalpin, 2006)

Ndc Clay subfacies (Miocene) - Greenish to greenish-gray, very fine-grained, unconsolidated, mostly massive clay to fine silt; locally has faint laminations. Clay beds may contain a significant component of volcanic ash. Some of the clay in these beds may be derived from the alteration of volcanic ash. Exposed in two parallel, north-northwest-trending, west-dipping zones. Individual clay beds are about 3-20 m thick; locally they are interbedded with very fine-grained siltstone (Shannon and McCalpin, 2006). Unit Ndc contains two ash beds (Nda) that yielded $\mathrm{Ar}^{40} / \mathrm{Ar}^{39}$ ages of $13.3 \pm 0.2 \mathrm{Ma}$ and $14.2 \pm 1.4 \mathrm{Ma}$ (location C, table 2; Hubbard and others, 2001), indicating middle Miocene age. Clay beds are interpreted as lacustrine. Thickness as much as $200 \mathrm{~m}$ (Shannon and McCalpin, 2006)

Nds Slide-block subfacies (Miocene)_Unit consists chiefly of large blocks of Paleozoic sedimentary rock that slid into sediments of the Dry Union Formation $(\mathrm{Nd})$. Blocks are composed of as much as $100 \mathrm{~m}$ of section of fractured and brecciated Ordovician and Devonian sedimentary rocks (Manitou Dolomite, Harding Sandstone, Fremont Dolomite, and Chaffee Group). Paleozoic quartzite beds and blocks of Proterozoic rocks are not brecciated (Shannon and McCalpin, 2006). Slide blocks locally composed of welded ash-flow tuff indicate emplacement of the slide blocks occurred after early Oligocene volcanism, but possibly before deposition of nearby beds that do not contain slide blocks but contain late Miocene vertebrate fossils (Van Alstine and Lewis, 1960; Van Alstine, 1970), based on current subdivision of Neogene time (U.S. Geological Survey, 2010). Original thickness unknown; locally at least $50 \mathrm{~m}$ thick (Van Alstine, 1970)

NPEb Browns Canyon Formation (Miocene or upper Oligocene)—Light-gray, reddish-gray, brown, and tan silicic, well indurated claystone, siltstone, sandstone, and conglomerate; conglomeratic arkose at base. Sandstone contains cherty grains. Claystone has conchoidal fracture. Exposed in several small areas on Browns Canyon horst (Nathrop 7.5' quadrangle; refer to map of regional geology). Overlies foliated Elephant Rock Granite (Ygef). Unit NPEb may be coeval with basal part of Dry Union Formation, although the Browns Canyon Formation locally contains plant fossils similar to those preserved in sediments of the Creede Formation in the San Juan Mountains to the southwest of the map area (Van Alstine and Cox, 1969) of late Oligocene age (Lanphere, 
2000). Browns Canyon Formation contains well-indurated beds as well as local fluorite mineralization, which are absent in the nearby Dry Union Formation (Van Alstine, 1971; Limbach, 1975). Preserved thickness less than about $10 \mathrm{~m}$

\section{OLIGOCENE AND EOCENE VOLCANIC AND MIXED VOLCANIC, VOLCANICLASTIC, AND SEDIMENTARY ROCKS}

\section{VOLCANIC ROCKS ASSOCIATED WITH EARLY RIO GRANDE RIFTING}

Pebf Vesicular basaltic-andesite flow (upper Oligocene)—Dark-gray, finely vesicular, massive basalt or basaltic-andesite porphyry; weathers pinkish-brown. Consists of about 25 percent plagioclase, both as small microlites and large (as long as $5 \mathrm{~mm}$ ) crystals, 6 percent augite, 2 percent hornblende, and 2 percent opaque minerals. Glassy matrix comprises about 65 percent of rock. Mapped as Grizzly Peak Tuff by Fridrich and others (1998). Only rubbly blocks exposed in two small areas about $1.7 \mathrm{~km}$ southwest of Twin Lakes dam. New ${ }^{40} \mathrm{Ar} /{ }^{39} \mathrm{Ar}$ age on hornblende is $24.12 \pm 0.12 \mathrm{Ma}$ (location D, table 2; Shroba and others, 2014); interpreted as mafic member of bi-modal assemblage related to early Rio Grande rifting

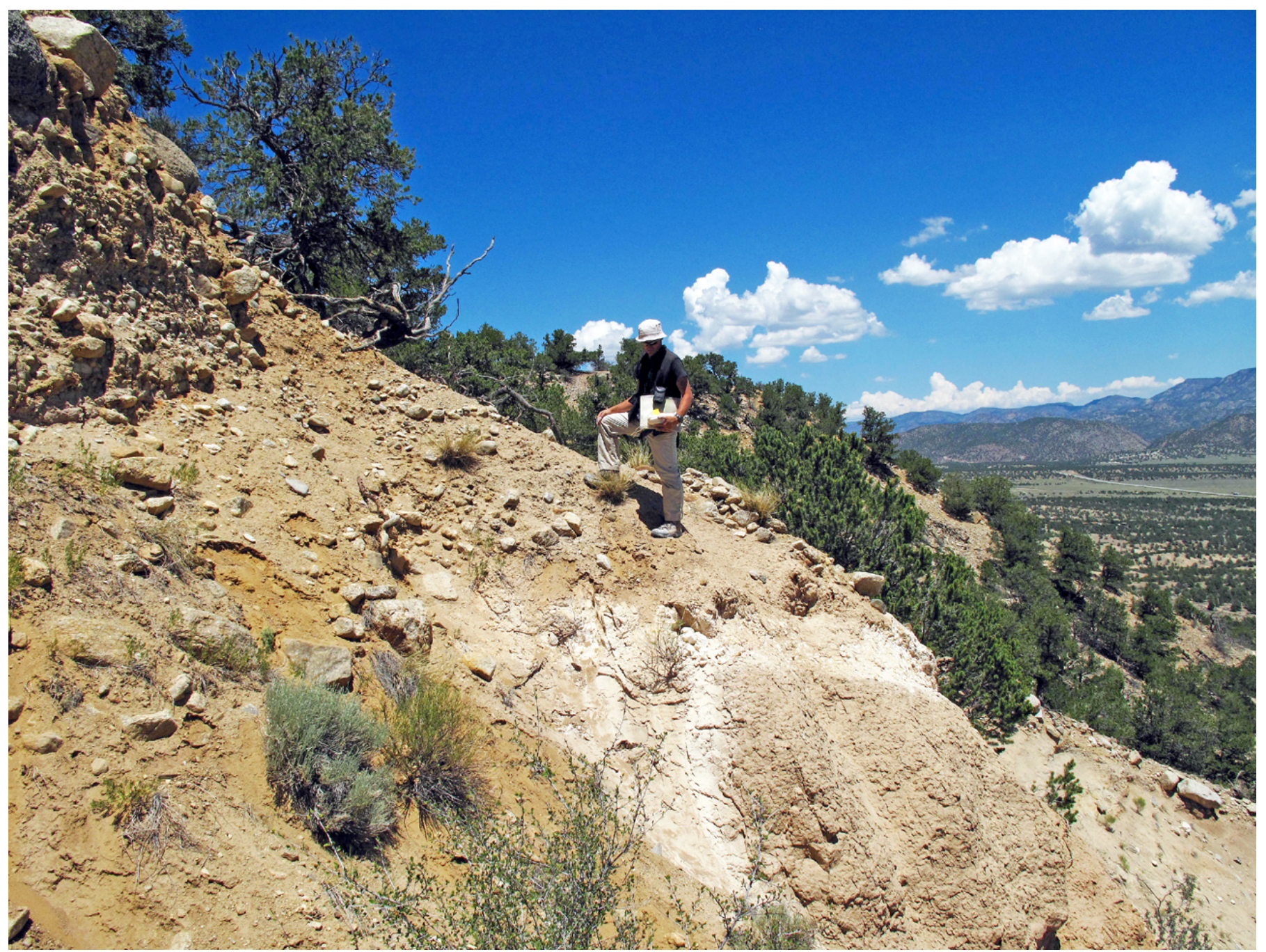

Figure 9. View north of ash bed (white layer $~ 30$ centimeters thick), about 1 meter [m] below the top of an exposed section of Dry Union Formation, just below the Qg2 outwash gravel deposit, on which the person is standing. Note the few clasts of unit Qg2 in colluvial mantle in lower left of photo. Photograph by Karl S. Kellogg, June 2012. 
Table 2. Isotopic ages for rocks in the upper Arkansas Valley region.

[No., line number; - , for symbol on map, indicates location uncertain or unit was sampled outside of the map area; - , for sample number, indicates no number given; $\sigma$, sigma, standard deviation; rhy, rhyolite; rasp., raspberry; p'phy, porphyry.]

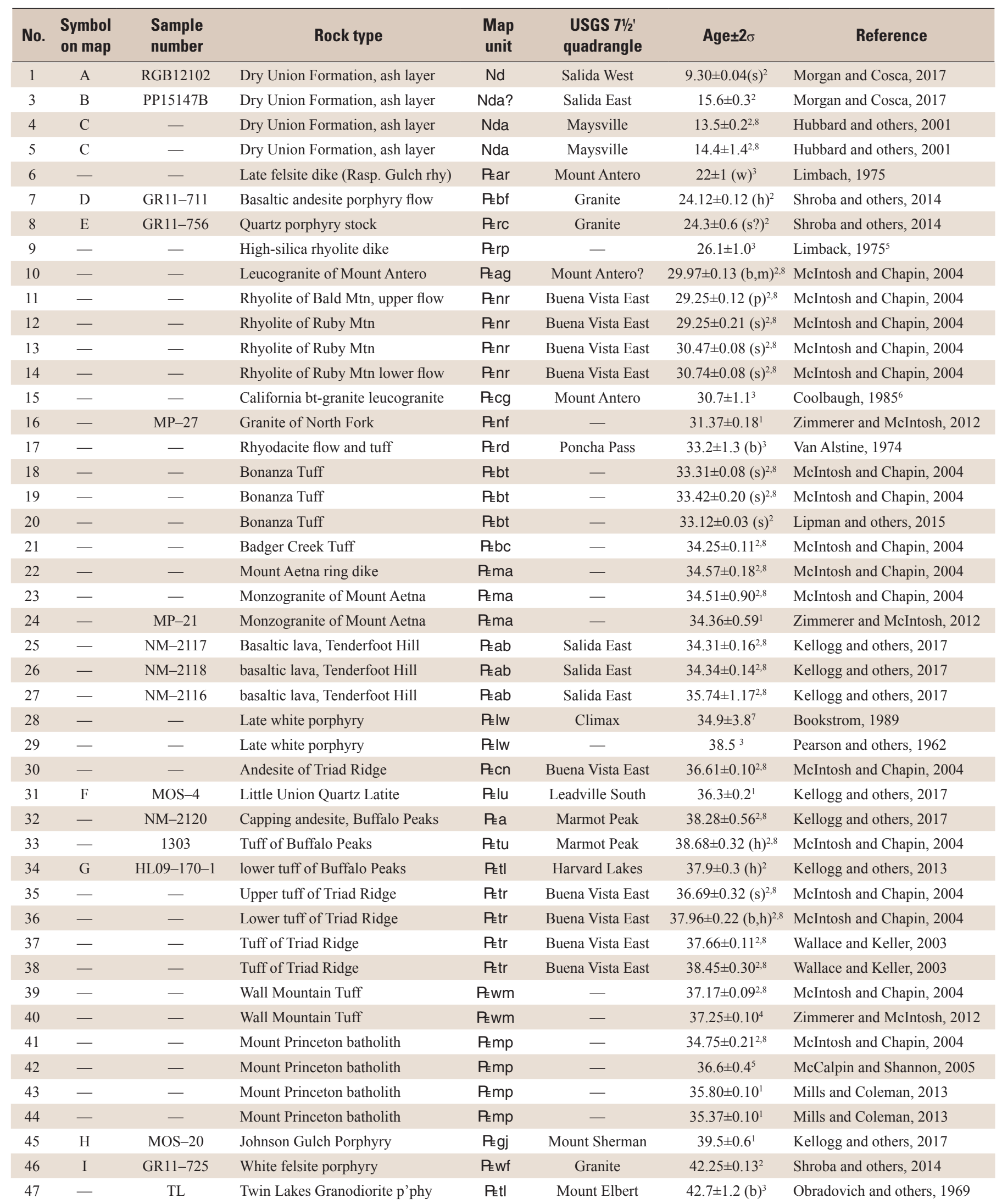


Table 2. Isotopic ages for rocks in the upper Arkansas Valley region.-Continued

[No., line number; - , for symbol on map, indicates location uncertain or unit was sampled outside of the map area; - , for sample number, indicates no number given; $\sigma$, sigma, standard deviation; rhy, rhyolite; rasp., raspberry; p'phy, porphyry.]

\begin{tabular}{|c|c|c|c|c|c|c|c|}
\hline No. & $\begin{array}{l}\text { Symbol } \\
\text { on map }\end{array}$ & $\begin{array}{l}\text { Sample } \\
\text { number }\end{array}$ & Rock type & $\begin{array}{l}\text { Map } \\
\text { unit }\end{array}$ & $\begin{array}{l}\text { USGS 71/2' } \\
\text { quadrangle }\end{array}$ & Age $\pm 2 \sigma$ & Reference \\
\hline 48 & - & R8-28-84-8a & Twin Lakes Granodiorite p'phy & Petl & Mount Elbert & $64.6 \pm 1.4(\mathrm{~h})^{2,8}$ & Fridrich and others, 1998 \\
\hline 50 & - & NM-2125 & Granite porphyry of Tumble Hill & Pegt & Jones Hill & $60.57 \pm 0.16^{2,8}$ & Kellogg and others, 2017 \\
\hline 51 & - & NM-2126 & Granite porphyry of Tumble Hill & Pegt & Jones Hill & $60.58 \pm 0.15^{2,8}$ & Kellogg and others, 2017 \\
\hline 54 & - & - & Granite porphyry of Black Mtn. & Pegp & Jones Hill & $60.97 \pm 0.15^{2}$ & Widmann and others, 2011 \\
\hline 55 & $\mathrm{~K}$ & HL09-44 & Monzodiorite dike & $\mathrm{PEKm}$ & Harvard Lakes & $65.3 \pm 0.5(b)^{2}$ & Kellogg and others, 2013 \\
\hline 56 & $\mathrm{~L}$ & HL09-89 & Hornblende syenodiorite & PEKm & Harvard Lakes & $65.4 \pm 0.5(b)^{2}$ & Kellogg and others, 2013 \\
\hline 57 & M & HL09-136 & Hornblende-biotite diorite plug & $\mathrm{PEKm}$ & Harvard Lakes & $68.1 \pm 0.9(b)^{2}$ & Kellogg and others, 2013 \\
\hline 58 & $\mathrm{~N}$ & USGS(D)G-A-82 & Rhyolite dike & $\mathrm{PEKW}$ & Granite & $65.3 \pm 2.4^{3}$ & Marvin and others, 1989 \\
\hline 62 & - & $9-13-84-1$ & Browns Pass Granite & Ybp & Mount Yale & $1,439 \pm 11^{1}$ & Moscati and others, 2012 \\
\hline 63 & - & $\mathrm{CO}-38$ & Browns Pass Granite & Ybp & Mount Yale? & $1,420 \pm 35(w)^{3}$ & Wetherill and Bickford, 1965 \\
\hline 64 & $\mathrm{O}$ & $8-3-83-1$ & Granodiorite of Mount Harvard & Ygdh & Mount Harvard & $1,414 \pm 20^{1}$ & Moscati and others, 2012 \\
\hline 65 & $\mathrm{P}$ & $9-8-83-1$ & Granodiorite of Mount Elbert & Ygdm & Mount Elbert & $1,415 \pm 15^{1}$ & Moscati and others, 2017 \\
\hline 66 & Q & WRP-03-6B & Granite of Granite & Ygrg & Granite & $1,429 \pm 9^{1}$ & Moscati and others, 2017 \\
\hline 67 & $\mathrm{R}$ & GR10-511 & Granite of Granite & Ygrg & Granite & $1,434 \pm 6^{1}$ & Moscati and others, 2017 \\
\hline 68 & $\mathrm{~S}$ & $8-31-84-3$ & Langhoff Gulch Granite & Ygl & Mount Sherman & $1,435 \pm 26^{1}$ & Moscati and others, 2017 \\
\hline 69 & $\mathrm{~T}$ & $9-1-84-10$ & St. Kevin Granite & Ygs & Mount Massive & $1,425 \pm 12^{1}$ & Moscati and others, 2017 \\
\hline 70 & $\mathrm{U}$ & HL09-53 & Langhoff Gulch Granite & Ygl & Harvard Lakes & $1,441 \pm 54^{1}$ & Moscati and others, 2017 \\
\hline 71 & $\mathrm{~V}$ & MP09-191 & Langhoff Gulch Granite & Ygl & Marmot Peak & $1,438 \pm 11^{1}$ & Moscati and others, 2017 \\
\hline 78 & $\mathrm{AA}$ & Bickford & Henry Mountain? Granite & Xgd & Cameron Mountain & $1,672 \pm 5^{1}$ & Bickford and others, 1989 \\
\hline 79 & $\mathrm{BB}$ & CM11-736 & Henry Mountain? Granite & Xgd & Cameron Mountain & $1,709 \pm 6^{1}$ & Moscati and others, 2017 \\
\hline 80 & $\mathrm{CC}$ & WRP03-8 & Metadacite of Salida & Xvs & Salida East & $1,732 \pm 4^{1}$ & Kellogg and others, 2017 \\
\hline 81 & DD & $\mathrm{Z}-3$ & Metadacite of Salida & Xvs & Salida East & $1,728 \pm 6^{1}$ & Bickford and others, 1989 \\
\hline
\end{tabular}

${ }^{1} \mathrm{Mean}{ }^{207} \mathrm{~Pb} /{ }^{206} \mathrm{~Pb}$ zircon age or U-Pb zircon concordia age.

${ }^{20} \mathrm{Ar} /{ }^{39} \mathrm{Ar}$ date. Mineral dated: $\mathrm{p}$, plagioclase; s, sanidine; $\mathrm{b}$, biotite; $\mathrm{m}$, muscovide; h, hornblende.

${ }^{3} \mathrm{~K} /$ Ar ages. Mineral dated: $\mathrm{b}$, biotite; h, hornblende; w, whole rock; no letter, not specified.

${ }^{4}$ Weighted mean of five ${ }^{40} \mathrm{Ar} /{ }^{39} \mathrm{Ar}$ ages in sanidine.

${ }^{5}$ Average of twenty-one K-Ar and fission-track ages.

${ }^{6}$ Recalculated by Shannon, 1988.

${ }^{7}$ Apatite fission-track age.

${ }^{8}$ Recalculated using revised standards for Fish Canyon Tuff sanidine (Kuiper and others, 2008). 
Penr Topaz rhyolite flow of Nathrop Volcanics, including basal vitrophyre (lower Oligocene)_Light-gray, light pinkish-gray, and purplish-gray, strongly flow-layered alkaline rhyolite flow forming prominent outcrops, about $8 \mathrm{~km}$ south-southeast of Buena Vista at Ruby Mountain, Sugarloaf Mountain, and upper part of Bald Mountain (Keller and others, 2004). Layering is moderately to strongly folded. The rhyolite consists of small, sparse phenocrysts of smoky quartz, sanidine, plagioclase, and rare biotite in a dense microcrystalline groundmass; accessory minerals are apatite, zircon, magnetite, garnet, and topaz (Keller and others, 2004). Locally contains spherules as much as $10 \mathrm{~cm}$ in diameter, and lithophysae as much as $6 \mathrm{~cm}$ in diameter, particularly on Bald Mountain. Lithophysal cavities locally contain euhedral crystals of spessartine garnet and topaz, some of gem quality (Voynick, 1994). The basal vitrophyre is glassy, composed mostly of light-gray, brownish-gray, or black perlite with subordinate pitchstone. The perlite typically shows an "onion-skin" structure. One ${ }^{40} \mathrm{Ar} /{ }^{39} \mathrm{Ar}$ age on plagioclase on Bald Mountain is $29.25 \pm 0.12 \mathrm{Ma}$, and three ${ }^{40} \mathrm{Ar} /{ }^{39} \mathrm{Ar}$ ages on sanidine at Ruby Mountain are 30.47 \pm 0.08 29.25 $\pm 0.21 \mathrm{Ma}$, and $30.74 \pm 0.08 \mathrm{Ma}$ (table 2; McIntosh and Chapin, 2004; ages corrected for revised standards of Kuiper and others, 2008), indicating early Oligocene age (McIntosh and Chapin, 2004). Similarity of age and composition (for example, presence of accessory topaz) with evolved Mount Antero leucogranites suite of Sawatch Range suggests genetic connection (Shannon, 1988). On Bald Mountain, the rhyolite is estimated to be about $150 \mathrm{~m}$ thick and was deposited within a paleovalley that also contains remnants of older Wall Mountain Tuff and Tallahassee Creek Conglomerate (Keller and others, 2004)

Pent Tuff and tuffaceous breccia of Nathrop Volcanics (lower Oligocene)_Light-pink, lighttan, and white, moderately indurated, rhyolitic, pumiceous tuff and tuffaceous breccia exposed on east sides of Sugarloaf and Ruby Mountains, beneath topaz-rhyolite flow of Nathrop Volcanics (Penr). Angular blocks include pumice, rhyolite, vitrophyre, and rare Proterozoic rocks. Pumice blocks as long as $1.2 \mathrm{~m}$ (Van Alstine and Cox, 1969), but most blocks less than $30 \mathrm{~cm}$ long. Matrix composed of devitrified glass and pumice. Interpreted as mudflow deposit by Scott (1975)

\section{PRE-RIFT VOLCANIC, VOLCANICLASTIC, AND SEDIMENTARY ROCKS}

PEbt

Bonanza Tuff (lower Oligocene) - Gray to pinkish-brown, porphyritic, devitrified welded rhyolite tuff, containing phenocrysts of chatoyant sanidine, biotite, sphene, and altered plagioclase; rare phenocrysts are augite and quartz; accessory minerals are zircon, apatite, and magnetite (Van Alstine, 1974). Locally shows eutaxitic, spherulitic, axiolitic and perlitic structures. Contains abundant fragments of rhyodacite from underlying rhyodacite flow and tuff unit (Perd) and Proterozoic rocks. Locally has a thin, black vitrophyre at base. Called "upper rhyolitic ash-flow tuff" by Van Alstine (1974); subsequently called Gribbles Park Tuff by Scott (1975), after Epis and Chapin (1974), who named it but did not recognize its source. Three ${ }^{40} \mathrm{Ar} /{ }^{39} \mathrm{Ar}$ ages on sanidine are 33.31 $\pm 0.08 \mathrm{Ma}, 33.42 \pm 0.20 \mathrm{Ma}$ (table 2; McIntosh and Chapin, 2004; ages corrected for revised standards of Kuiper and others, 2008), and 33.12 $\pm 0.03 \mathrm{Ma}$ (table 2; Lipman and others, 2015. Overlies rhyodacite flow and tuff (Perd) in southwest corner of Salida West 7.5' quadrangle. Source now recognized as 32.8-Ma Bonanza caldera, about $25 \mathrm{~km}$ southwest of Salida (Lipman and others, 2015)

Pzbc Badger Creek Tuff (lower Oligocene or upper Eocene)—Shown only in the Salida East 7.5' quadrangle (Wallace and others, 1997) where it consists of an upper, welded tuff member and a lower, nonwelded tuff member. Regionally the Badger Creek Tuff is a compound cooling unit composed of at least six separate flows (Epis and Chapin, 1974). In the map area, the upper, welded tuff is a light-gray, light-yellowish-gray and light-reddish-gray quartz latite that contains prominent phenocrysts of plagioclase and biotite, with less prominent phenocrysts of sanidine and hornblende. Contains distinctive and abundant fragments of light-grayish white to light pink pumice and lapilli, and dark-red, dark-gray, and black fragments of glassy and aphanitic volcanic rocks (Wallace and others, 1997).

Nonwelded member is thin or absent in the northern outcrops shown on map, where 
unit lies directly on Paleozoic rocks. To the south, the lower, nonwelded tuff member is a brightly colored, light-grayish-white, light-yellowish brown, and light-reddish-gray ash-flow and multiple-cooling-unit ash-flow tuff that forms prominent hoodoos. Air-fall deposits composed primarily of pumice fragments are a minor component of the lower unit. Thickness of lower nonwelded unit as much as $90 \mathrm{~m}$. The Badger Creek Tuff fills the Waugh Mountain paleovalley in the Salida East 7.5' quadrangle (Wallace and others, 1997 ) where it is more than $120 \mathrm{~m}$ thick. $\mathrm{U} / \mathrm{Pb}$ zircon age is $34.83 \pm 0.22 \mathrm{Ma}$ (Zimmerer and McIntosh, 2012; table 2), while ${ }^{40} \mathrm{Ar} /{ }^{39} \mathrm{Ar}$ age on sanidine is $34.25 \pm 0.11 \mathrm{Ma}$ (McIntosh and Chapin, 2004; age corrected for revised standards of Kuiper and others, 2008). Source is Mount Aetna caldera in southern part of Sawatch Range

Perd Rhyodacite flow and tuff (lower Oligocene or upper Eocene)—Gray-brown porphyritic rhyodacitic lava flows make up most of this unit $3 \mathrm{~km}$ southwest of Poncha Springs. Contains vitrophyric layers and interbedded tuffs; upper part contains white vitric layers and brown lithic tuff containing rhyodacite fragments (Van Alstine, 1974). Locally perlitic and displays columnar and platy structures. Contains abundant phenocrysts of plagioclase and biotite; rare sanidine, augite, hypersthene, and hornblende. Accessory minerals are opaque minerals, apatite, zircon, and fluorite. Groundmass is microcrystalline aggregate of feldspar, quartz, and biotite. Contains brown interbedded tuffaceous layers that are probably part of the composite Badger Creek Tuff. Potassium-argon (K-Ar) age on biotite is $33.2 \pm 1.3 \mathrm{Ma}$ (table 2, Van Alstine, 1974). Overlies Wall Mountain Tuff (PEwm; lower ash-flow tuff of Van Alstine, 1974). Thickness about $45 \mathrm{~m}$.

Petc

PEab

Tallahassee Creek Conglomerate (lower Oligocene and upper Eocene?)—Polymict, cobble and boulder conglomerate in a tuffaceous matrix, containing subangular to rounded clasts of Mesoproterozoic granitic rocks, Manitou Dolomite, Harding Sandstone, Fremont Dolomite, Eocene andesite, Wall Mountain Tuff, and distinctive silicified wood fragments; the wood fragments distinguish the Tallahassee Creek Conglomerate from the similar-appearing Antero Formation and Quaternary terrace deposits east of map area (Wallace and Keller, 2003). Contains clasts of Paleozoic rocks as much as $1.5 \mathrm{~m}$ in diameter and of Proterozoic granodiorite boulders as much as $10 \mathrm{~m}$ in diameter (De Voto, 1971); granodiorite boulders reported in the Buena Vista East 7.5' quadrangle as much as $4 \mathrm{~m}$ in diameter (Keller and others, 2004). Locally contains light-gray to light-yellowish gray, poorly stratified, slightly welded quartz-latite tuff layers containing pumice fragments and reddish, aphanitic volcanic clasts. Deposited in paleovalleys with steep walls by high-energy mud-flows or debris flows from Sawatch Range to the west; landslides from surrounding Paleozoic rocks locally slid into unit (Wallace and Keller, 2003). Overlies late Eocene tuff of Triad Ridge (PEtr) and the late Eocene Wall Mountain Tuff (PEwm). Immediately east of map area unit is unconformably overlain by the early Oligocene Antero Formation (not exposed in map area), which contains tuffaceous beds with ${ }^{40} \mathrm{Ar} /{ }^{39} \mathrm{Ar}$ ages of $34.42 \pm 0.10 \mathrm{Ma}$ (McIntosh and Chapin, 2004; corrected for revised standards of Kuiper and others, 2008) and $34.03 \pm 0.09 \mathrm{Ma}$ (Kirkham and others, 2012). Matrix is poorly indurated, so most exposures consist of bouldery and cobbly lag deposits. Estimated thickness as much as $15 \mathrm{~m}$

Basalt, andesite, and latite flows, and associated plugs (upper Eocene)—Consists mostly of pahoehoe flows, aa flows, lahar breccias, and mudflow breccias of andesitic or basaltic composition just north of Salida (andesite and basalt unit of Wallace and others, 1997). Some gravels or mudflow breccias interlayered with basalt flows on Tenderfoot Hill, just north of Salida. Flows and breccia clasts are dark gray or black, locally vesicular, dense, and nonporphyritic to slightly porphyritic. Includes andesite of Big Baldy Mountain, probably an intrusive plug (Wallace and others, 1997), which may be feeder to some of the flows. Near top of sequence near Tenderfoot Hill is biotite latite, a light-gray to pinkish gray porphyry flow with abundant plagioclase phenocrysts as long as $7 \mathrm{~mm}$ (Wallace and others, 1997). The sequence of gravel or possibly mudflow breccias that underlies Tenderfoot Hill contains clasts as large as boulders; interlayered basalt flows have three ${ }^{40} \mathrm{Ar} /{ }^{39} \mathrm{Ar}$ ages of $34.31 \pm 0.16 \mathrm{Ma}, 34.34 \pm 0.14 \mathrm{Ma}$, and 35.74 $1.17 \mathrm{Ma}$ (late Eocene; Kellogg and others, 2017; table 2). Lowell (1971) erroneously included these gravels at Tenderfoot Hill with the Dry Union Formation 
Pers Rhyodacite lava of Salida East (upper Eocene?)—Grayish-pink to pinkish-brown, prominently layered, eutaxitic, porphyritic lava flows. Glassy groundmass contains microlites, abundant plagioclase phenocrysts, and less abundant biotite phenocrysts. Prominent lithophysae have formed in some layers. Estimated as much as $60 \mathrm{~m}$ thick, but draped over a surface of considerable relief. Overlies Paleozoic sedimentary rocks at one locality in Salida East 7.5' quadrangle (Wallace and others, 1997) about $4 \mathrm{~km}$ east of Salida. Considered by Wrucke and Dings (1979) as Miocene, but similarity with upper or middle Eocene volcanic rocks of region makes older age more reasonable

Pecn Capping andesite porphyry of Triad Ridge of Thirtynine Mile Andesite (upper Eocene) Dark-gray when fresh; reddish or orange-brown on weathered surfaces. Crystal-rich (40 volume percent) with abundant euhedral plagioclase phenocrysts, subordinate hypersthene and augite, and sparse biotite (Limbach, 1975). Groundmass consists of plagioclase and pyroxene microlites (Scott, 1975). Columnar jointing well developed. Forms narrow outcrop along crest of Triad Ridge, infilling Trout Creek paleovalley; incised into softer, upper Eocene tuff of Triad Ridge (Keller and others, 2004). ${ }^{40} \mathrm{Ar} /{ }^{39} \mathrm{Ar}$ age is 36.61 $\pm 0.10 \mathrm{Ma}$ (table 2; McIntosh and Chapin, 2004). Member of extensive upper Eocene Thirtynine Mile Andesite complex that forms flows and breccias mostly east of map area (Epis and Chapin, 1974). Limbach (1995) suggested that this unit was related to the volcanic rocks of the Buffalo Peaks, which is possible, although ${ }^{40} \mathrm{Ar} /{ }^{39} \mathrm{Ar}$ age is slightly younger. Maximum thickness estimated as $60 \mathrm{~m}$ (Keller and others, 2004)

Pewm Wall Mountain Tuff (upper Eocene) - The main body of the tuff, named by Epis and Chapin (1974), is light gray to light-brownish gray and grayish pink, moderately to densely welded rhyolitic ash-flow tuff with abundant phenocrysts of sanidine and plagioclase; biotite is sparse (Epis and Chapin, 1974). The basal 2.5-4 m is black, glassy vitrophyre that contains phenocrysts of quartz and sanidine. The tuff is a simple cooling unit with common eutaxitic texture. Laminar flow foliation is locally well developed. Deposited in steep-walled, northeast-trending paleovalleys incised into previously erupted tuff of Triad Ridge, older Proterozoic rocks, or Paleozoic rocks (Keller and others, 2004). Folded deformational features (rheomorphic folds) were produced locally when the tuff slid into paleovalleys. Overlies tuff of Triad Ridge in Trout Creek paleovalley. Weathers light-orange brown to buff in rounded outcrops. Unit includes lower ash-flow tuff of Van Alstine (1974), interpreted as Wall Mountain Tuff by Scott (1975), mapped in large area north of Salida (Van Alstine, 1974) where it overlies basalt and andesite flows and mudflow breccias (unit PEab), and in small area in southwestern part of Salida West 7.5' quadrangle where it underlies rhyodacite flow and tuff (Perd). Van Alstine (1974) describes this unit as containing a basal black, densely welded vitrophyre as thick as $6 \mathrm{~m}$ containing $60-70$ percent brown glass with fluidal layering, perlitic structures, shards, and abundant crystal fragments of sanidine, oligoclase-andesine, biotite, magnetite, apatite, zircon, and rare augite. Overlying the basal vitrophyre is pinkishgray to reddish-brown porphyritic and devitrified welded tuff containing abundant sanidine, oligoclase-andesine, biotite, small Proterozoic rock fragments, and rare quartz, crystobalite, tridymite, magnetite, apatite, zircon, fluorite, sphene, and topaz. Pollen and spores from unwelded basal zone indicate Oligocene age (Van Alstine and Cox, 1969), which is slightly younger than ${ }^{40} \mathrm{Ar} /{ }^{39} \mathrm{Ar}$ sanidine age of $37.25 \pm 0.10 \mathrm{Ma}$ (table 2; weighted mean of five samples; Zimmerer and McIntosh, 2012). $\mathrm{A}^{40} \mathrm{Ar} /{ }^{39} \mathrm{Ar}$ sanidine age of 37.17 \pm 0.09 Ma was reported earlier by McIntosh and Chapin (2004) and other earlier-reported potassium-argon ages are $34.7 \pm 0.7 \mathrm{Ma}$ and $36.2 \pm 0.8 \mathrm{Ma}$ on sanidine, and $35.7 \pm 0.8 \mathrm{Ma}$ on biotite (Epis and Chapin, 1974). Thickness as much as $60 \mathrm{~m}$.

Epis and Chapin (1974) first suggested that the Wall Mountain Tuff originated from a deeply eroded caldera in the Mount Princeton region, although the 35.8-35.4 Ma age (Mills and Coleman, 2013) for the Mount Princeton intrusion is significantly younger than the 37.2 Ma Wall Mountain Tuff. This discrepancy probably reflects that the tuff erupted during relatively early stages of batholithic emplacement and cooling of the batholith occurred over a protracted period. In addition, the $34.8 \mathrm{Ma}$ emplacement of the Mount Aetna caldera (McIntosh and Chapin, 2004) may have caused slight argon loss and locally reset the age of the Mount Princeton batholith (Shannon and McCalpin, 2006) 
Petr Tuff of Triad Ridge (upper Eocene) — Light-gray, light-tan, light-reddish-gray, and lightorange-gray, moderately to densely welded dacitic tuff with abundant pumice and lithic fragments. Crystal-rich (25-30 volume percent) with abundant plagioclase and biotite phenocrysts and lesser sanidine, hornblende, and quartz (Keller and others, 2004). Groundmass is devitrified glass with axiolitic or spherulitic textures (Bade, 1989). Locally contains flattened glass and pumice fragments. Most rock shows compaction foliation (eutaxitic texture) parallel to topography. Informally called tuff of Castle Rock Gulch by Wallace and Keller (2003), who report ${ }^{40} \mathrm{Ar} /{ }^{39} \mathrm{Ar}$ ages of $37.66 \pm 0.11 \mathrm{Ma}$ on biotite and 38.45 $\pm 0.30 \mathrm{Ma}$ on hornblende (table 2). McIntosh and Chapin (2004) informally renamed the unit tuff of Triad Ridge and reported a lower and upper member, although the two were not megascopically distinguishable by Keller and others (2004). The ${ }^{40} \mathrm{Ar} /{ }^{39} \mathrm{Ar}$ age for the lower tuff of Triad Ridge is $37.96 \pm 0.22$ on both biotite and hornblende; the upper tuff of Triad Ridge has a ${ }^{40} \mathrm{Ar} /{ }^{39} \mathrm{Ar}$ age on sanidine of $36.69 \pm 0.32 \mathrm{Ma}$ (table 2, McIntosh and Chapin, 2004), which is slightly but significantly younger than the Wall Mountain Tuff (37.25 $\pm 0.10 \mathrm{Ma}$, table 2, Zimmerer and McIntosh, 2012), implying that the Wall Mountain Tuff may be stratigraphically interlayered with the tuff of Triad Ridge. Tuff of Triad Ridge underlies Wall Mountain Tuff in the Castle Rock Gulch 7.5' quadrangle (Wallace and Keller, 2003), so the unit in this area is probably the lower tuff of Triad Ridge. Fills prominent Trout Creek paleovalley, now topographically inverted along and near crest of Triad Ridge. Source of tuff of Triad Ridge is unknown. Thickness as much as $210 \mathrm{~m}$

Resb Trout Creek slide block (Eocene?)-Highly fractured, orange-brown and ochre mass east of Triad Ridge composed of jasperoid or chert derived from hydrothermal alteration of Manitou Dolomite (Om) and (or) Fremont Dolomite (Of) in a large block that slid westward into a paleovalley from a source now obscured by tuff of Triad Ridge ( $P$ tr) about $10 \mathrm{~km}$ east of Johnson Village. The displacement of the slide block, therefore, predates deposition of the tuff of Triad Ridge. A site near the eastern boundary of the Buena Vista East 7.5' quadrangle, called the "Trout Creek chert quarry," includes several pits where silicified material was mined by Native Americans as early as 8,000 B.C. to early historic times and was traded throughout the Rocky Mountain region (Keller and others, 2004)

PEra Rhyodacite porphyry flow, ash, and mud-flow deposit of Van Alstine and Cox (1969) (upper or middle Eocene)-Poorly consolidated, greenish-gray-weathering rhyodacitic ash about $4 \mathrm{~m}$ thick, overlies Proterozoic rock just west of Arkansas River in the Nathrop 7.5' quadrangle (Van Alstine and Cox, 1969) and northern Salida West 7.5' quadrangle (Van Alstine, 1974). Ash is overlain by, and interbedded with, white, argillized rhyodacite tuff locally cut by veinlets of chalcedonic silica, calcite, and gypsum. Rhyodacite ash locally includes a volcanogenic mudflow deposit, consisting of rhyodacitic cobbles and pebbles in a greenish ash matrix. Mudflow contains silicified wood, which suggests possible correlation with Tallahassee Creek Conglomerate ( $\mathrm{Ptc}$ ). Locally includes a gray-brown rhyodacite lava flow as thick as $15 \mathrm{~m}$ with phenocrysts of labradorite, augite, and hypersthene in a conspicuously flow-banded, locally glassy groundmass. Strong weathering before deposition of overlying lower Oligocene rocks suggests age is late or middle Eocene. Similar to, and possibly correlative with, some lithologies of volcaniclastic sediment and ash (PEva), which underlie upper Eocene Wall Mountain Tuff, about $13 \mathrm{~km}$ north of unit

Pecr Calico rhyodacite lava of Shannon (1988) (upper? Eocene)—Porphyritic biotitehornblende rhyodacite lava interbedded with minor welded ash-flow tuff and porphyritic andesite; tuff breccia is included in unit PEcr west of map area (Shannon, 1988). Only the northeast end of a belt of this unit is exposed in the map area, about 2-3 km southwest of Mount Antero in the Sawatch Range. The unit strikes east-northeast and dips moderately south-southeast. Predates collapse of Mount Aetna caldera and is intruded by the $31 \mathrm{Ma}$ leucogranite of the California Mine ( $\mathrm{PECg}$ ), so age is probably late Eocene. Dings and Robinson (1957) described a unit occupying approximately the same area as a fine-grained, grayish-green to dark-greenish-gray "andesite" with small phenocrysts of white or light greenish-gray plagioclase and common small pyrite grains; 
propylitic alteration pervasive. The sequence overlies Proterozoic gneiss and granodioritic rocks of Mount Princeton batholith and is about $110 \mathrm{~m}$ thick

Quartz-latite porphyry flow (upper? Eocene)—Generally gray, weakly flow-banded, poorly exposed porphyritic extrusive volcanic rock containing small phenocrysts of plagioclase, sanidine, and biotite in an aphanitic groundmass; accessory minerals are opaque minerals, sphene, apatite, and zircon. Moderately to strongly weathered. May locally include ash-flow tuff. Mapped on basis of float in two small areas in western Buena Vista West 7.5' quadrangle, just south of Bald Mountain in the Sawatch Range (McCalpin and Shannon, 2005), where it overlies Paleoproterozoic gneiss. Overlies and preserves only known remnant of late Eocene erosion surface (except for surface beneath volcanic rocks in down-dropped subsidence block of Mount Aetna caldera) exposed on east side of southern Sawatch Range (McCalpin and Shannon, 2005). Total original thickness is unknown

Peva Volcaniclastic conglomerate and ash (upper? Eocene) — Light-gray to green, poorly to moderately unconsolidated, poorly exposed, medium- and fine-grained, silty and sandy, volcaniclastic conglomerate; locally ashy. Contains well-rounded to subrounded pebbles, cobbles, and small boulders of Proterozoic quartzite and granitic rocks, mostly as lag deposits. Parts of unit resembles younger Tallahassee Creek Conglomerate, but unit is older because it underlies upper Eocene Wall Mountain Tuff (PEwm) at one locality in eastern Buena Vista East 7.5' quadrangle; overlies Proterozoic granitic rocks (Keller and others, 2004). Age is probably late Eocene

\section{UPPER EOCENE VOLCANIC ROCKS OF BUFFALO PEAKS CENTER}

Pean Andesite-Dark greenish-gray andesite porphyry flow capping East and West Buffalo Peaks and Thunder Mountain. Very fine-grained matrix, mostly plagioclase and disseminated magnetite-ilmenite granules (Hedlund, 1985), comprises about 60 percent of rock. Phenocrysts are approximately 25 percent euhedral, strongly saussuritized andesine $\left(\mathrm{An}_{40-43}\right)$ as long as $8 \mathrm{~mm}, 9$ percent euhedral to subhedral augite, 4 percent ilmenite and magnetite, 2 percent strongly altered (to opaque minerals) hornblende, 1 percent hypersthene, and trace sphene. Some andesine strongly pitted and have overgrowths of more sodic andesine $\left(\mathrm{An}_{37}\right)$ (Hedlund, 1985). Locally contains lightgray fine-grained angular lithic fragments as long as $1 \mathrm{~cm}$. Rock strongly jointed, with light-green, fine-grained material (probably epidote and chlorite) in partings parallel to joints. Includes both upper and lower andesite units on Thunder Mountain of Widmann and others, (2011), separated by a $\sim 5$-m-thick, poorly exposed air-fall and ash-flow tuff $(\mathrm{P} a \mathrm{a})$. Andesite below the tuff coarser grained than above the tuff. Basal andesite flow breccia consists of reddish-gray, frothy, moderately welded ash-flow tuff containing reddish or purplish dense andesite clasts as long as $30 \mathrm{~cm}$. Figure 10 shows a view to the north, of Buffalo Peaks

$\mathrm{PEvb} \quad$ Volcanic breccia-Reddish to light-gray tuff and breccia that underlies and is interlayered with andesite unit (PEan) on East and West Buffalo Peaks. Breccia blocks are as long as $2 \mathrm{~m}$ and lie in a tuffaceous, vesiculated matrix that has a high glass/crystal ratio (Houck and others, 2012); crystals within the matrix include strongly altered plagioclase and amphibole. Basal layer is a strongly welded tuff as thick as $30 \mathrm{~m}$, with both sharp and gradational contacts with either andesite ( $\mathrm{PEan}$ ) or upper tuff ( $\mathrm{P}$ tu)

Petu

Upper tuff-Light-gray, densely welded, cliff forming ash-flow tuff containing black, collapsed, glassy pumice clasts as long as $30 \mathrm{~cm}$. As much as 30 volume percent phenocrysts, including of oligoclase, hornblende, and accessory quartz, biotite, clinopyroxene, apatite, and iron oxide minerals (Hedlund, 1985). Matrix consists of glass (partially devitrified) with a swirling flow texture. Tuff is chemically a dacite (Widmann and others, 2011) and has ${ }^{40} \mathrm{Ar} /{ }^{39} \mathrm{Ar}$ date on hornblende of 38.18 $\pm 0.32 \mathrm{Ma}$ (table 2; McIntosh and Chapin, 2004). Thickness about $150 \mathrm{~m}$

Pea Air-fall and ash-flow tuff-Light- to medium-gray, poorly stratified, coarse ash devoid of crystal or lithic fragments, and light-gray to yellowish-gray, densely welded crystallithic ash-flow tuff (Widmann and others, 2011). Contains as much as 20 percent 


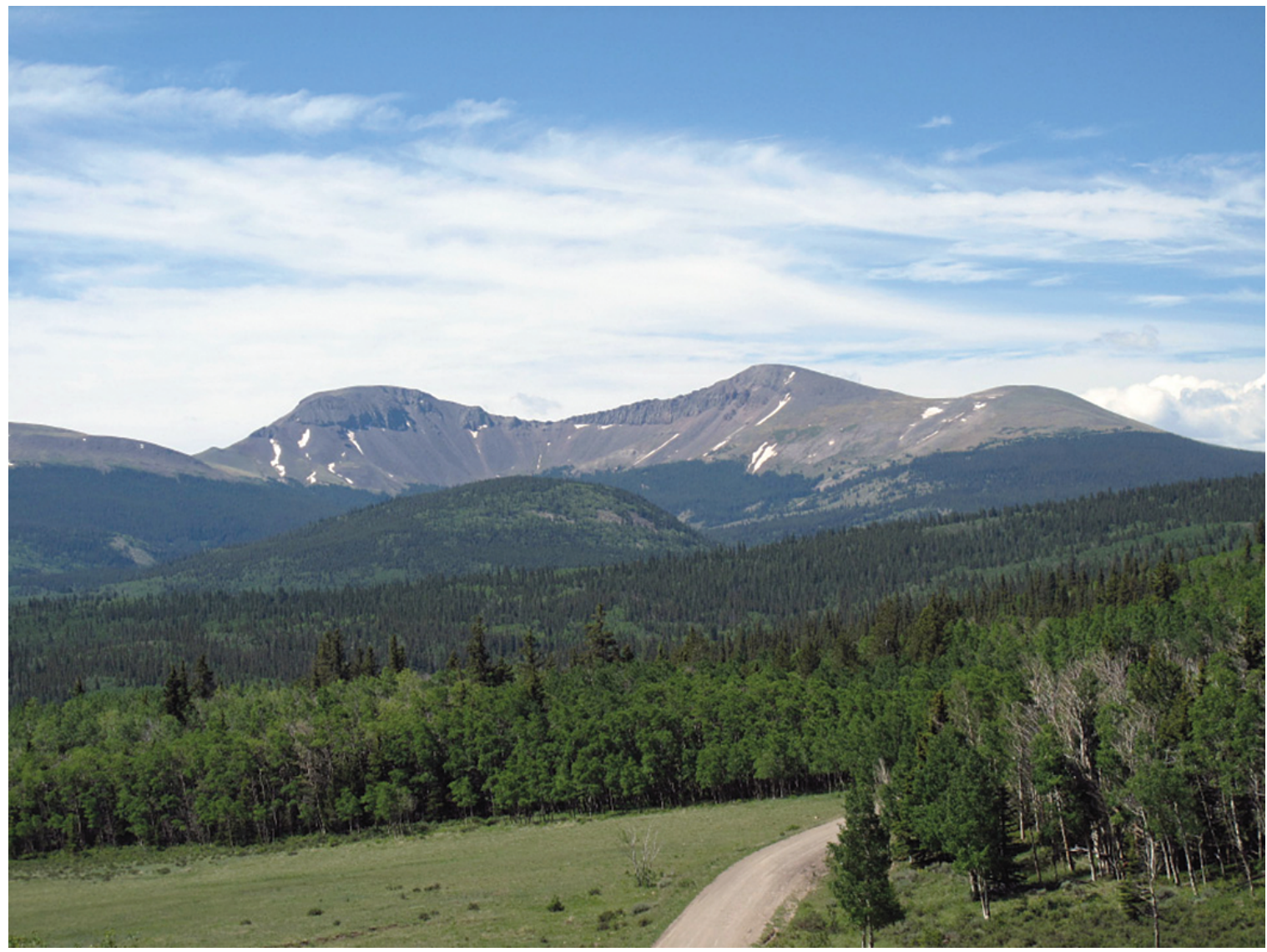

Figure 10. View to the north of Buffalo Peaks, which are composed mostly of andesite flows, andesite breccias, lahars, and welded tuff deposited on Mesoproterozoic granite. The peak on the left is West Buffalo Peak (4,062 meters [m]; 13,326 feet [ft]) and the peak on the right is East Buffalo Peak (4,054 m; 13,330 ft). Photograph by Karl Kellogg, 2011.

hornblende (to $6 \mathrm{~mm}$ ), andesite fragments, chalky (weathered) pumice fragments, and sparse, small $(<2 \mathrm{~mm})$ quartz crystals. Mostly poorly exposed. Mapped at two separate stratigraphic horizons: within upper, finer-grained and lower, coarser-grained andesite (PEan), and between upper tuff ( $\mathrm{P}_{\mathrm{E}} \mathrm{tu}$ ) and lahar deposit ( $\mathrm{P}$ la) on east side of Thunder Mountain. Estimated thickness less than $10 \mathrm{~m}$

Lahar deposit—Reddish-brown weathering, poorly sorted volcaniclastic mudflow consisting of angular blocks of medium- to dark-gray andesite as long as $10 \mathrm{~m}$ in a matrix of ash and broken rock fragments. Composition of blocks similar to that of lower part of andesite unit (PEan). Lahar must have been very hot when deposited, because matrix has a pyroclastic texture composed mostly of potassium feldspar, glass, andesite fragments, and small broken phenocrysts of biotite, plagioclase, and clinopyroxene. A biotite ${ }^{40} \mathrm{Ar} /{ }^{39} \mathrm{Ar}$ age from an andesite clast is $38.39 \pm 0.14 \mathrm{Ma}$ (Widmann and others, 2011). Thickness about 75-90 m

Petl Lower tuff-Similar in character and chemistry to upper tuff unit (PEtu) (Widmann and others, 2011). Contains abundant collapsed black pumice clasts. Broken crystals of oligoclase, hornblende, biotite, clinopyroxene, and accessory quartz comprise about 25 percent of rock; also contains sparse lithic fragments. New ${ }^{40} \mathrm{Ar} /{ }^{39} \mathrm{Ar}$ age on hornblende is $37.9 \pm 0.3 \mathrm{Ma}$ (table 2; Kellogg and others, 2013). Total thickness about $90 \mathrm{~m}$

Rebal Basal andesite-White, strongly altered ("bleached") andesite with assumed composition similar to cap andesite ( $\mathrm{P}$ an) exposed over several meters just above Mesoproterozoic Elephant Rock Granite (Yge). Prominent near-horizontal platy jointing. Estimated thickness $10 \mathrm{~m}$ 


\title{
TERTIARY AND LATE CRETACEOUS INTRUSIVE ROCKS
}

\author{
ROCKS ASSOCIATED WITH EARLY RIO GRANDE RIFTING
}

Perp Late rhyolite porphyry dikes and plugs of Mount Princeton region (late Oligocene) -

White, light-pinkish-gray, locally greenish rhyolite porphyry containing about 20 percent phenocrysts of quartz, potassium feldspar, plagioclase, and minor (about 1 percent) biotite. Commonly garnet bearing. $\mathrm{K}$-Ar age on one sample is $26.1 \pm 1.0 \mathrm{Ma}$ (Limbach, 1975, recalculated by Shannon, 1988) using revised decay constants of Dalrymple, 1979). One chemical analysis (McCalpin and Shannon, 2005) indicates rock is a high-silica (75.6 percent $\left.\mathrm{SiO}_{2}\right)$, low calcium $(0.2$ percent $\mathrm{CaO})$ alkali rhyolite. The dikes comprise the felsic member of the bimodal Cascadia dike swarm of Shannon (1988) and display considerable textural variation. At least some may be associated with the 29.6 Ma Mount Antero intrusion (Shannon, 1988). Dikes mostly intrude rocks of the Mount Princeton batholith and Proterozoic rocks just south of the batholith. In and near Chalk Creek, dikes are oriented north-northeast and dip about $40^{\circ}$ northwest. Late rhyolite porphyry dikes include rhyolite of Raspberry Gulch of Limbach (1975), a pink to tan, very fine-grained porphyry exposed in four wide, dike- or plug-like bodies that intrude the eastern part of Mount Princeton batholith (PEmpm) about $3 \mathrm{~km}$ south of Mount Princeton Hot Springs; contain phenocrysts of quartz and plagioclase (oligoclase) in an aphanitic groundmass. Reported whole-rock K-Ar age on Raspberry Gulch rhyolite of $22 \pm 1 \mathrm{Ma}$ (table 2; Limbach, 1975), but age probably slightly young. Also includes undated north-striking monzogranite dikes in central part of the Mount Princeton batholith (Shannon, 1988)

PEl

Olivine-augite lamprophyre dike (late Oligocene?)—Black lamprophyre dikes containing about $7-18$ percent olivine and augite phenocrysts $\leq 2 \mathrm{~mm}$ in a fine-grained groundmass of plagioclase-augite-biotite-hornblende-magnetite (McCalpin and Shannon, 2005); typically, dike margins are chilled. Locally contains spessartite garnet (Shannon, 1988). Olivine generally altered. $\mathrm{SiO}_{2}$ content is very low (43.4 percent), but rock has an elevated $\mathrm{K}_{2} \mathrm{O}$ content (3.5 percent) (McCalpin and Shannon, 2005). Lamprophyre dikes are as thick as $3 \mathrm{~m}$, intrude rocks of the Mount Princeton batholith, and cut the late Oligocene rhyolite porphyry dikes (Prp). Suggested as the mafic member of a bimodal assemblage (Shannon, 1988), the felsic members of which include the evolved granite of the late Oligocene Mount Antero leucogranite suite and the late rhyolite porphyry dikes and plugs of Mount Princeton region (PErp). Along with the late porphyry dikes and plugs of the Mount Princeton region, forms the bimodal Cascadia dike swarm of Shannon (1988)

Pedt Microtonalite (Oligocene?)—Gray, fine-grained, massive, poorly exposed rock consisting of an altered mosaic composed mostly of quartz and plagioclase. Contains about 20 percent anhedral quartz, 65 percent very sericitic plagioclase, 7 percent biotite (almost entirely altered to chlorite, epidote and hematite), 4 percent opaque minerals and 3 percent secondary muscovite. Exposed only as float, just west of Clear Creek rhyolite hypabyssal pluton (Perc) in USGS Granite 7.5' quadrangle, and tentatively associated with that unit

Perc Hypabyssal rhyolite of Clear Creek (late Oligocene)—Pale pinkish-gray, porphyritic rhyolite?, composed of about 60 percent glass with abundant quartz and feldspar microlites. Phenocrysts as long as $3 \mathrm{~mm}$ are comprised of about 25 percent fragmental quartz, 9 percent altered (sericitic) plagioclase, 10 percent sanidine, 1 percent biotite, and trace opaque minerals. Contains many subrounded fragments and clasts of Proterozoic gneiss as long as $1.5 \mathrm{~cm}$. Locally contains small vugs. Float only exposed on ridge on the south side of the Clear Creek Reservoir near southeastern corner of Granite 7.5' quadrangle. ${ }^{40} \mathrm{Ar} /{ }^{39} \mathrm{Ar}$ age on sanidine is $24.3 \pm 0.6 \mathrm{Ma}$ (location E,table 2; Shroba and others, 2014)

Leucogranite Suite of Mount Antero

Pear Rhyolite dike (early? Oligocene)—North-striking, flow-layered rhyolite dikes west and north of main body of Mount Antero intrusion. Correlated with leucogranite suite of 
Mount Antero on basis of chemistry and petrology. Mapped by Shannon (1988) with minimal description

Reap Border phase (early Oligocene) - Very light-gray, fine-grained (aplitic) porphyry, consisting of about 48 percent alkali feldspar and unspecified percentages of quartz, plagioclase, and biotite phenocrysts in a fine-grained aplitic matrix (Shannon, 1988). Border phase is as much as $100 \mathrm{~m}$ thick

Peag Main phase (early Oligocene) — Very light gray, medium-grained, Be-rich granite composed chiefly of alkali feldspar, quartz, plagioclase $\left(\sim \mathrm{An}_{10}\right)$, accessory magnetite, ilmenite, monazite, fluorite, beryl, and zircon. Also contains fine-grained white mica considered as late magmatic (Shannon, 1988). Rock is very siliceous (as much as 80 percent $\mathrm{SiO}_{2}$ ). Cut by numerous light-pink aplite and pegmatite dikes and irregularshaped bodies. ${ }^{40} \mathrm{Ar} /{ }^{39} \mathrm{Ar}$ age for main phase of leucogranite suite of Mount Antero is $29.97 \pm 0.13 \mathrm{Ma}$ (table 2; mean of two biotite and two muscovite ages; McIntosh and Chapin, 2004), essentially identical to the 29-30 Ma topaz rhyolites of Nathrop Volcanics, with which it is inferred to be genetically related (Shannon, 1988). The main phase of the Mount Antero leucogranite suite was formerly mapped as part of the "Mount Pomeroy quartz monzonite" intrusion (for example, Dings and Robinson, 1957)

Pecg Leucogranite of the California Mine (early Oligocene)-Includes a very light-gray, finegrained border phase and a medium-grained leucogranite interior phase (Shannon, 1988). Also includes fine-grained dikes south of the main body of leucogranite (Shannon and McCalpin, 2006). Fine-grained border phase locally contains a few phenocrysts of quartz and feldspar. The interior phase is a medium-grained biotite leucogranite, containing alkali feldspar, quartz, plagioclase $\left(\sim \mathrm{An}_{10}\right)$, biotite, spessartine garnet, and accessory magnetite, ilmenite, monazite, fluorite, zircon, and tourmaline. Unit includes volumetrically minor aplite porphyry. Leucogranite of the California Mine is cut by numerous pegmatites with miarolitic cavities locally containing blue beryl (aquamarine) (Adams, 1953; Sharp, 1976). Greisen zones in and adjacent to the California intrusion also contain cavities lined with quartz, white mica, fluorite, beryl, and molybdenite. Named for the California Mine (Worcester, 1919), a molybdenum prospect near the head of Browns Creek, that also contains beryl-bearing quartz veins (Adams, 1953). K-Ar age is $30.7 \pm 1.1 \mathrm{Ma}$ (table 2; Coolbaugh, 1985, adjusted by Shannon, 1988, using revised decay constants of Dalrymple, 1979). Shannon (1988) reports that the leucogranite of the California Mine cuts the 29.97 Ma leucogranite suite of Mount Antero, which is barely permissible on the basis of the isotopic ages. Formerly mapped as part of the "Mount Pomeroy quartz monzonite" intrusion (for example, Dings and Robinson, 1957; Sharp, 1976)

\section{PRE-RIFT INTRUSIVE ROCKS}

Penf Granite and granite dikes of North Fork (early Oligocene)—Consist of a variable- textured, very-light-gray, fine-grained, biotite monzogranite to aplite border unit as thick as $100 \mathrm{~m}$, and a medium-grained biotite leucogranite interior unit (Shannon, 1988). Contains alkali feldspar, quartz, plagioclase $\left(\sim \mathrm{An}_{10}\right)$, biotite, and accessory magnetite, ilmenite, monazite, fluorite, and zircon. Crops out in an irregular, approximately 3-km-wide body about $8 \mathrm{~km}$ south of Mount Antero. K-Ar age is 31.6 $\pm 1.1 \mathrm{Ma}$ (Pulfrey, 1971; revised by Shannon (1988), using revised decay constants of Dalrymple (1979). A more precise U/Pb zircon age is $31.37 \pm 0.18 \mathrm{Ma}$ (Zimmerer and McIntosh, 2012. Includes several north-northeasttrending granitic dikes with similar composition to the leucogranite interior unit

Peqmo Quartz monzodiorite (early Oligocene)-Medium- to dark-gray, very fine-grained, equigranular, containing approximately 10 percent quartz, 8 percent alkali feldspar, 60 percent plagioclase, 10 percent biotite, 8 percent hornblende, 2 percent clinopyroxene, and 2 percent total magnetite, sphene, allanite, apatite, and zircon. Forms three wide, dike-like bodies south and southwest of Mount Shavano in the Maysville and Garfield 7.5' quadrangles (Shannon and McCalpin, 2006; Dings and Robinson, 1957). Mineralogy and texture are similar to phases of the Mount Princeton batholith, although ${ }^{40} \mathrm{Ar}{ }^{39} \mathrm{Ar}$ age of 32.8 $\pm 0.3 \mathrm{Ma}$ (Shannon and McCalpin, 2006; corrected for revised standards of Kuiper and others, 2008) is considerably younger than the Mount Princeton intrusion 
Petm Porphyritic latite dike of Shannon (1988) (early Oligocene?)-Several very fine-grained latite porphyry dikes of varying orientation intruding granite of the Mount Princeton batholith and adjacent Proterozoic gneiss. Includes the porphyritic latite dikes and quartz latite porphyry hybrid dikes of Taylor Mountain of Shannon (1988) and Shannon and McCalpin (2006). Age uncertain, but field relationships suggest these dikes are younger than the quartz latite porphyry ring dikes of Mount Aetna (Shannon and McCalpin, 2006)

\section{Rocks of the Mount Aetna Caldera (Early Oligocene or Late Eocene)}

The main body of monzonitic rocks of the Mount Aetna caldera, on and near Mount Aetna just west of the map boundary, is not exposed in the map area. Granitic rocks (using an outdated terminology), were formally named Mount Aetna Quartz Monzonite Porphyry by Dings and Robinson (1957); however, most rock is more properly a monzogranite (International Union of Geological Sciences [IUGS] IUGS classification; Le Bas and Streckeisen, 1991)

Pema Quartz latite porphyry ring dike-Gray, strongly porphyritic, massive biotite-hornblende quartz latite dikes as thick as about $120 \mathrm{~m}$ that crop out in a roughly arcuate pattern. Contain characteristic large tabular orthoclase phenocrysts as long as $4 \mathrm{~cm}$ and abundant plagioclase phenocrysts as long as about $1 \mathrm{~cm}$. Only the northeastern part of the ring-dike complex crops out in the map area. Represents the youngest rock associated with eruption of the Mount Aetna caldera. U/Pb zircon age is $34.68 \pm 0.26 \mathrm{Ma}$ (Zimmerer and McIntosh, 2012); average of twenty-one $\mathrm{K}-\mathrm{Ar}$ and fission-track ages is $34.4 \mathrm{Ma}$ (McCalpin and Shannon, 2005). U/Pb zircon age of Mount Aetna monzogranite which gave rise to the ring dike, is $34.36 \pm 0.59 \mathrm{Ma}$ (table 2; Zimmerer and McIntosh, 2012), while high-precision ${ }^{40} \mathrm{Ar}{ }^{39} \mathrm{Ar}$ ages on the monzogranite (just west of map area), have a mean of $34.57 \pm 0.18 \mathrm{Ma}$ (table 2; McIntosh and Chapin, 2004; corrected for revised standards of Kuiper and others, 2008). Based largely on similarity in age and petrology, Mount Aetna caldera produced the 34.83-Ma Badger Creek Tuff exposed east of Arkansas River (table 2)

Peib Intrusive breccia-Greenish dike-like bodies composed entirely of angular to sub-angular fragments and crystals of Mount Princeton plutonic rock in a very fine matrix of crushed rock; do not appear to contain any magmatic phase (McCalpin and Shannon, 2005).

Pervasively altered to chlorite and epidote. Bodies are as narrow as about $1 \mathrm{~cm}$, as wide as about $1 \mathrm{~m}$, and in most places are parallel to anastomosing shear zones as wide as several hundred meters; only a few of the larger bodies shown on map in the northwestern part of the Garfield 7.5' quadrangle. Apparently do not cut ring dike ( $\mathrm{P}$ ma), which they therefore predate. Intrusive breccias both cut and are cut by ring shears, indicating both processes are approximately contemporaneous. Outcrop patterns suggest intrusive breccias (and ring shears) are vertical to steeply inward dipping. Unit includes "flinty crush rock" of Shannon (1988). Intrusive breccia interpreted as emplaced by fluidization processes related to episodic venting of magmatic gases and fluids during collapse of the Mount Aetna caldera (Shannon, 1988; McCalpin and Shannon, 2005)

$\mathrm{PEm} \quad$ Monzonite and latite dikes (early Oligocene or late Eocene)—Monzonite dikes are gray to greenish gray with conspicuous phenocrysts of feldspar, quartz, and local hornblende. Dikes of latite composition are light to medium gray and contain small phenocrysts of quartz, feldspar, or both, although some are aphanitic. These undated dikes were mapped in the Garfield 7.5' quadrangle (Dings and Robinson, 1957) and intrude rocks of the Mount Princeton batholith, as well as Paleozoic sedimentary rocks, but do not intrude the Mount Antero Granite, suggesting an age of early Oligocene or late Eocene

REIw Late white porphyry (late Eocene) - White to light-gray, fine-grained rhyolite porphyry. Porphyry forms north-northeast-trending dikes in southern Climax 7.5' quadrangle (McCalpin, Temple, and others, 2012), just west of Mount Evans. Contains sparse quartz, orthoclase, and plagioclase phenocrysts as long as $2 \mathrm{~mm}$ in an aphanitic matrix. Very similar to rocks of the older white porphyry group, but apatite fission-track age is 34.9 $\pm 3.8 \mathrm{Ma}$ (table 2; Bookstrom, 1989)

PElu Little Union Quartz Latite (late Eocene)-Medium- to dark-brownish-gray, quartz latite containing about 60 percent brownish glass matrix, 25 percent plagioclase crystals, 5 percent angular quartz, 5 percent biotite, and smaller amounts of orthoclase (a few 
as large phenocrysts); minor and accessory minerals are magnetite, green hornblende, apatite, zircon, and sphene (Behre, 1953). Described by Emmons (Emmons and others, 1886) but named by Behre (1953). Rock is distinctly brownish in color and is unaltered in all outcrops. Intrudes all rocks of the gray porphyry group ( $\mathrm{PEgp}$ ); U-Pb zircon age is $36.3 \pm 0.2 \mathrm{Ma}$ (location F, table 2; Kellogg and others, 2017). Forms several sill-like bodies along Little Union Gulch, about $7 \mathrm{~km}$ south of Leadville. Includes a latite porphyry breccia forming an elongate body just southwest of Timberline Lake, locally composed of boulder-size and smaller fragments of Proterozoic granite in a matrix of fine-grained, highly sericitized latite, or quartz latite porphyry. Locally lacks fragments of Proterozoic granite (Tweto, 1974a), is pyritized, and was the target for drilling by Bear Creek Mining Company, who report a K-Ar age from drill core of 35.4 $\pm 1.2 \mathrm{Ma}$ (Tweto, 1974a)

\section{Rocks of the Mount Princeton Batholith}

The age of the Mount Princeton batholith is somewhat controversial. Mills and Coleman (2013) report ${ }^{206} \mathrm{~Pb} /{ }^{238} \mathrm{U}$ zircon ages of $35.80 \pm 0.10 \mathrm{Ma}$ and $35.37 \pm 0.10 \mathrm{Ma}$, while McCalpin and Shannon (2005) report an average of $21 \mathrm{~K} / \mathrm{Ar}$ and fission-track ages of 36.6 $\pm 0.4 \mathrm{Ma}$ (table 2). McIntosh and Chapin (2004), averaging nine ${ }^{40} \mathrm{Ar} /{ }^{39} \mathrm{Ar}$ age determinations, report a weighted mean age of $34.75 \pm 0.21 \mathrm{Ma}$ (table 2; corrected for revised standards of Kuiper and others, 2008). The older U-Pb zircon age is compatible with the age for the 37-Ma Wall Mountain Tuff, which Epis and Chapin (1974) first suggested is the outflow tuff from a long-eroded caldera in the Mount Princeton region. One possible explanation for the discrepancy is that the $34.8 \mathrm{Ma}$ emplacement of the Mount Aetna caldera caused slight argon loss in the rocks of the Mount Princeton batholith and reset the ${ }^{40} \mathrm{Ar} /{ }^{39} \mathrm{Ar}$ age (Shannon and McCalpin, 2006). Another factor is that the Mount Princeton batholith cooled much more slowly than the Wall Mountain Tuff and therefore might be expected to have a younger isotopic age

PEmp Granitic rock of Mount Princeton batholith, undivided (late Eocene)—Shown in the northernmost part of the pluton where character of the rock uncertain. Most likely composed of equigranular biotite-hornblende monzogranite of interior facies ( $\mathrm{P} \in \mathrm{mpm})$ or finer-grained facies (PEmpf). Rocks of the batholith named Mount Princeton Quartz Monzonite by Dings and Robinson (1957) using an outdated terminology; most rock is more properly a monzogranite (IUGS classification; Le Bas and Streckeisen, 1991)

Pebqm Boulder Mountain monzogranite porphyry of Shannon (1988) (early Oligocene or late Eocene)-Porphyritic monzogranite with fine- to medium-grained matrix that forms wide (as much as $300 \mathrm{~m}$ ) dike-like body that intrudes roof zone and border phase ( $\mathrm{PEmpb}$ ) of the Mount Princeton batholith (Shannon, 1988) just west of Mount Antero. Undated, but may represent remobilized interior phase of the Mount Princeton pluton that intruded the chilled carapace of the pluton, so tentatively included with rocks of the Mount Princeton batholith. Not studied in detail and not mapped by Dings and Robinson (1957)

PEmpf Finer-grained facies-Light pinkish-gray, medium-grained, equigranular biotitehornblende quartz monzogranite that forms bodies inboard from the border phase $(\mathrm{P} m p b)$. Finer grained and contains less total mafic minerals than the interior phases ( $P$ mpm and $P$ mpk); average of three modal analyses show unit contains about 24 percent quartz, 29 percent potassium feldspar, 35 percent plagioclase, and 10 percent biotite plus hornblende (Shannon, 1988)

PEmpk Alkali-feldspar monzogranite-Pinkish-gray, medium-grained monzogranite porphyry containing conspicuous tabular potassium feldspar phenocrysts (as much as 20 percent of rock) as long as about $3 \mathrm{~cm}$ and quartz phenocrysts as long as about $0.5 \mathrm{~cm}$. Average of five modal analyses indicates about 25 percent quartz, 30 percent potassium feldspar, 36 percent plagioclase, 9 percent biotite plus hornblende, and 1 percent accessory magnetite, sphene, allanite, apatite, and zircon (Shannon, 1988). Forms an irregular layer inboard from the finer-grained facies ( $\mathrm{P} \mathrm{mpf}$ )

PEmpm Equigranular biotite-hornblende monzogranite interior facies-Light-gray, medium- to coarse-grained, equigranular monzogranite. Average of six modal analyses indicates about 24 percent quartz, 28 percent potassium feldspar, 37 percent plagioclase, 10 percent biotite plus hornblende, and accessory large sphene (easily visible in hand specimen), magnetite, allanite, apatite, and zircon (Shannon, 1988). Predominant phase of the Mount Princeton batholith, forms the major unit along South Cottonwood Creek and Chalk Creek 
Pempp Augite-bearing granodiorite porphyry-Gray, medium- to coarse grained augitebearing granodiorite porphyry of Shannon (1988); little detailed description provided

PEmpb

Border phase-Fine to medium-grained, mostly equigranular monzogranite that has a slightly higher ratio of potassium feldspar to plagioclase and less mafic minerals than interior phases. Locally includes aplite porphyry, with phenocrysts of plagioclase, potassium feldspar, quartz, and biotite in a fine-grained potassium feldspar groundmass (McCalpin and Shannon, 2005). Forms a border unit in the northern part of the batholith as thick as about $100 \mathrm{~m}$; relationships with Proterozoic rocks suggest contact dips outward

Eocene and Paleocene Intrusive Intermediate and Felsic Rocks

Peai

Intrusive andesite (late Eocene?) — Small body, about $1.5 \mathrm{~km}$ south of main sequence of volcanic rocks of Buffalo Peaks, composed of two distinct facies (Kellogg and others, 2013). Eastern, more extensive facies composed of dark greenish-gray, fine-grained, equigranular rock containing mostly sericitic plagioclase, hornblende, and opaque minerals; well layered parallel to fracture cleavage. Smaller, western facies composed of black, aphanitic, massive, porphyritic rock containing about 5 percent hornblende crystals as long as $3 \mathrm{~mm}$, about 2 percent plagioclase crystals as long as about $2 \mathrm{~mm}$, and about 1 percent olivine crystals as long as $1 \mathrm{~mm}$ in an aphanitic groundmass; mineralogy suggests basaltic andesite composition. Interpreted as intrusive and possible source for at least some andesitic extrusive rocks (PEan) of Buffalo Peaks, in which case unit is about $38 \mathrm{Ma}$

Pegp Gray porphyry group, undivided (Eocene and Paleocene)—Mostly light-gray, lightbluish-gray, greenish-gray and grayish-tan, locally purplish-tan-weathering, granite porphyry including both monzogranite and granodiorite. The name "gray porphyry" was coined by early miners to distinguish the mostly grayish, conspicuously porphyritic intrusive rocks from the mostly finer-grained rocks of the older white porphyry group, which contains few ferromagnesian minerals. The gray porphyry group includes the Sacramento, Eagle River, Evans Gulch, Johnson Gulch, Mount Zion, and Iowa Gulch Porphyries (Emmons and others, 1927; Behre, 1953; Pearson and others, 1962), and at least some of the Lincoln Porphyry; some confusion exists concerning the age of the latter (see below). The Johnson Gulch, Sacramento, Eagle River, and Lincoln Porphyries are shown separately on the map where they are large enough to show at map scale. The gray porphyry group also provisionally includes a small andesitic plug in South Peak 7.5' quadrangle, a dark-gray, fine-grained, massive, biotite-rich rock with about 15 percent diffuse plagioclase phenocrysts as long as one $\mathrm{cm}$. Most mapped bodies of gray porphyry group, undivided, pre-date emplacement of Johnson Gulch Porphyry (Behre, 1953). The gray porphyry group was emplaced during a magmatic episode that peaked at about $40 \mathrm{Ma}$, but continued to decline until about $35 \mathrm{Ma}$. A very similar range in ages was determined from about $40 \mathrm{~K}-\mathrm{Ar}$ and fission-track age determinations on gray-porphyry-groups rocks in the Breckenridge and South Park region, east of the map area (Bryant and others, 1981)

Pegj

Johnson Gulch Porphyry (Eocene)—Medium-gray, porphyritic monzogranite or granodiorite typically with a fine-grained or very fine-grained groundmass. Contains about 30 percent small, euhedral plagioclase phenocrysts, 5 percent subhedral quartz phenocrysts as long as about $5 \mathrm{~mm}, 5$ percent biotite as long as $1 \mathrm{~mm}$, and a few percent hornblende needles as long as $5 \mathrm{~mm}$; contains only a few orthoclase phenocrysts as long as $2.5 \mathrm{~cm}$ (Behre, 1953). Accessory minerals are apatite, zircon, and rutile. Considered the darkest-gray and youngest of the gray porphyries (Behre, 1953). Forms dikes, sills, and small stocks and is probably the igneous rock most closely associated with ore deposition (Behre, 1953). The Johnson Gulch Porphyry underlies most of Breece Hill, several kilometers east of Leadville, which contains many of the major ore deposits of the Leadville mining district. The Johnson Gulch Porphyry has a zircon fission-track age of 43.1 $\pm 4.3 \mathrm{Ma}$ (Thompson and Arehart, 1990) and a recent $\mathrm{U}-\mathrm{Pb}$ zircon age of 39.5 $\pm 0.6 \mathrm{Ma}$ (location H, table 2; Kellogg and others, 2017) grained porphyry. Contains 30 percent plagioclase phenocrysts, mostly $\sim 3 \mathrm{~mm}$ but up 
to $1.5 \mathrm{~cm}$ long, quartz as long as $2 \mathrm{~cm}$, greenish biotite as wide as $0.75 \mathrm{~cm}$, and hornblende as long as $0.75 \mathrm{~cm}$ in a quartz-rich matrix (Behre, 1953). Forms a large stock or sill-like body in the Climax and Mount Sherman 7.5' quadrangles on the east side of the Mosquito Range (McCalpin, Temple, and others, 2012; Bohannon and Ruleman, 2013)

Per

PEgl

Pedi

Pewf

Pemd

Regional Paleogene and Late Cretaceous Intrusive Rocks

Pegt Granite porphyry of Tumble Hill (Paleocene) - Very light-gray, pinkish-gray to light bluish-gray massive quartz-feldspar monzogranite porphyry mapped at Black Mountain, Tumble Hill, and in a sill-like body intruded between Leadville Limestone (MI) and 
Belden Formation $(\mathbb{P b})$ in Jones Hill (Widmann and others, 2011) and Harvard Lakes (Kellogg and others, 2013) 7.5' quadrangles. Phenocrysts are quartz (euhedral to subhedral, as long as $1 \mathrm{~cm}$ in Black Mountain pluton and finer grained in other plutons), chalky-white zoned, potassium feldspars, and biotite. Matrix is fine- to very fine-grained mosaic of quartz, feldspar, and biotite. In Tumble Hill pluton, Hedlund (1985) also noted minor apatite, oxyhornblende, and iron oxides. ${ }^{40} \mathrm{Ar} /{ }^{39} \mathrm{Ar}$ age on sanidine for the granite porphyry of Black Mountain is $60.97 \pm 0.15 \mathrm{Ma}$ (table 2; Widmann and others, 2011), and the granite porphyry of Tumble Hill in the Jones Hill 7.5' quadrangle is $60.64 \pm 0.17 \mathrm{Ma}$ (table 2, Kellogg and others, 2017, ages corrected for revised standards of Kuiper and others, 2008). The sill-like body is pervasively altered and undated, but similarity to other granite porphyry bodies of unit $\mathrm{PEgt}$ and proximity suggests that it is coeval

Petlg Twin Lakes Granodiorite (Paleocene)—Gray to tan, medium- to coarse-grained, equigranular to strongly porphyritic biotite granodiorite and monzogranite. Most rocks contain distinctive, euhedral to subhedral pinkish-gray orthoclase phenocrysts as long as $10 \mathrm{~cm}$; some show prominent Carlsbad twinning. Core zone is more leucocratic and less porphyritic (Fridrich and others, 1998). The Twin Lakes Granodiorite batholith is cut by numerous quartz monzonite porphyry dikes (Cappa and Bartos, 2007). Sphene fissiontrack ages and one K-Ar biotite age from the Twin Lakes Granodiorite range from 40 to $46 \mathrm{Ma}$ (Obradovich and others, 1969; Shannon, 1988). These ages may have been reset by emplacement of 33-Ma Grizzly Peak caldera immediately to the west; $\mathrm{a}^{40} \mathrm{Ar} /{ }^{39} \mathrm{Ar}$ date considered more representative of emplacement age, from eastern part of batholith,

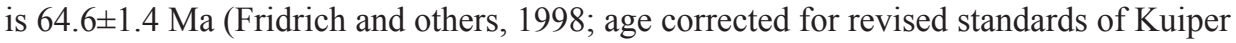
and others, 2008)

PEKw Early white porphyry group (Paleocene or Late Cretaceous)—White to light gray, buff weathering, non-porphyritic to porphyritic rhyolite or fine-grained monzogranite that forms sills, dikes and laccolithic bodies in the northern part of the map area. Contains phenocrysts of subhedral to euhedral quartz and conspicuous biotite in an aphanitic to fine-grained groundmass, which consists of quartz, biotite, and rare plagioclase and orthoclase; accessory minerals include magnetite, zircon, apatite, and hornblende (Cappa and Bartos, 2007); coarser grained groundmass observed in thicker sills. Unit was called "early white porphyry" by Emmons and others (1927) and Behre (1953). Correlated with the Pando Porphyry near Gilman and north of Leadville (Tweto, 1951) on the basis of a K-Ar age for the Pando that is $71.8 \mathrm{Ma}$ (table 2, Cunningham and others, 1994); in poor agreement with a recent $\mathrm{U}-\mathrm{Pb}$ zircon age of $64.1 \pm 0.9 \mathrm{Ma}$ (location J, table 2; Kellogg and others, 2017). A clast of probable early white porphyry collected from a conglomerate immediately east of the Alma $7.5^{\prime}$ quadrangle yielded an age of $64.08 \pm 0.11 \mathrm{Ma}$ (Widmann and others, 2005; dating method not stated). Numerous apatite fission-track ages are between about 50-40 Ma (Beaty and others, 1990) and are clearly reset. Unit includes white to light-gray, glassy to finely crystalline rhyolite and quartz latite dikes as wide as about $10 \mathrm{~m}$ containing phenocrysts of bipyramidal quartz as long as about $5 \mathrm{~mm}$, feldspar, and biotite; fracture chonchoidal and glassy. Generally nonporphyritic white felsite dikes of Scott (1975) also included in this unit

PEKdi Diorite sill (Paleocene or Late Cretaceous) - Dark gray, brown-gray, and green, equigranular, medium-grained, composed of about 20-30 percent euhedral hornblende, 60-70 percent altered, subhedral plagioclase, $3-4$ percent magnetite, and trace amounts of biotite and pyroxene (Wallace and Keller, 2003). Mafic minerals are strongly chloritized. Sill was called monzonite by Wallace and Keller (2003), but potassium feldspar not positively identified. Margins are finer-grained and slightly more silicic than interior. Unit is undersaturated with respect to silica, although no feldspathoid minerals were identified (Wallace and Keller, 2003). Locally forms large (more than $1,500 \mathrm{~m}$ long) monzodiorite sill intruded between the Leadville Limestone and Belden Formation, mostly in the Castle Rock Gulch 7.5' quadrangle (Wallace and Keller, 2003) about $11 \mathrm{~km}$ northeast of Buena Vista

PeKd Rhyodacite and dacite plugs and dikes (Paleocene or Late Cretaceous)—Medium- to light-gray porphyritic dikes containing prominent white phenocrysts of plagioclase, as 
much as 10 percent black biotite, and as much as 2 percent opaque minerals. Locally contains sparse garnet. Matrix is very fine grained plagioclase-quartz intergrowth with abundant fine-grained secondary muscovite or sericite. Most plagioclase is strongly sericitic. Dull luster on fractures. Includes rhyodacite and dacite dikes of Scott (1975). Several mines and prospects are in or adjacent to dacite dikes in the Harvard Lakes 7.5' quadrangle, suggesting a genetic connection between dike emplacement and mineralization (Kellogg and others, 2013). Dikes mostly less than $10 \mathrm{~m}$ wide. Dacitic to rhyolitic dikes in the Buena Vista East 7.5' quadrangle are overlain by the $\sim 38$-Ma tuff of Triad Ridge (Keller and others, 2004; McIntosh and Chapin, 2004), so these dikes are middle Eocene or older. Unit most likely intruded during Late Cretaceous and early Paleocene period of regional silicic magmatism

PEKm Hornblende monzonite, monzodiorite, and gabbro (Paleocene or Late Cretaceous) Includes several mafic stocks and dikes along an east-northeast trend, from near the headwaters of Frenchman Creek in the Sawatch Range to Buffalo Creek, east of the Arkansas River. Four individually described units in this group include: (1) an eastwest trending, 3-km-long, undated, mostly gabbroic stock near the headwaters of Morrison Creek near the Lienhart Mine; the stock is zoned, ranging in composition from dark-greenish-black, coarse-grained gabbro to tan, medium-grained granophyre (Fridrich and others, 1998); (2) an oblong 0.8-km-long stock just south of Morrison Creek (in $\mathrm{N}^{1} / 2$ sec. 4, T. 13 S., R. 79 W.); the rock is dark gray, medium-grained, equigranular, massive monzonite (IUGS classification; Le Bas and Streckeisen, 1991) containing, in one typical thin section, about 53 percent plagioclase, 34 percent microcline, 7 percent hornblende, 2 percent clinopyroxene, 2 percent large (to $2 \mathrm{~mm}$ ) sphene, 1 percent biotite, 1 percent hypersthene, and 1 percent opaque minerals; contains no visible quartz; ${ }^{40} \mathrm{Ar} /{ }^{39} \mathrm{Ar}$ biotite age is $65.4 \pm 0.5 \mathrm{Ma}$ (location $\mathrm{L}$, table 2; Kellogg and others, 2013); (3) a 20-m-wide, east-striking dike, about $200 \mathrm{~m}$ south of Morrison Creek, that is dark gray, fine grained, equigranular, massive and contains about 50-60 percent very sericitized plagioclase and microcline, 25 percent biotite, 10 percent hornblende, 5 percent opaque minerals, and no visible quartz; ${ }^{40} \mathrm{Ar} /{ }^{39} \mathrm{Ar}$ biotite age is $65.3 \pm 0.5 \mathrm{Ma}$ (location $\mathrm{K}$, table 2; Kellogg and others, 2013); and (4) a cluster of small mafic stocks along Buffalo Creek, east of the Arkansas River, composed of gray, massive gabbro or diorite porphyry containing conspicuous phenocrysts of hornblende as long as $1 \mathrm{~cm}$ in fine- to medium-grained matrix; one thin section contains 55 percent zoned subhedral to euhedral plagioclase as long a $1.5 \mathrm{~mm}, 17$ percent euhedral hornblende containing abundant secondary biotite, 19 percent both primary and secondary biotite, 6 percent magnetite, 2 percent clear to slightly undulatory quartz, and trace apatite and sphene; stocks form one $0.7-\mathrm{km}$ long, crescent-shaped plug along Buffalo Creek and two smaller plugs several hundred meters south; ${ }^{40} \mathrm{Ar} /{ }^{39} \mathrm{Ar}$ age on biotite is $68.1 \pm 0.9 \mathrm{Ma}$ (location M, table 2; Kellogg and others, 2013); includes a small (several tens of meters wide) plug about $5 \mathrm{~km}$ southeast of other units, consisting of dark greenish-gray, massive, very fine grained, nonporphyritic hornblende-plagioclase-chlorite (after biotite) rock

Kwg Whitehorn Granodiorite (Late Cretaceous) - Rocks of a stock and laccolith that intruded Paleozoic and Paleoproterozoic rocks along the southeast part of the map area (Wallace and others, 1997; Wallace and Lawson, 1998). Rock is fine to medium grained, equigranular, massive, hypidiomorphic-seriate, biotite granodiorite that contains varietal hornblende and pyroxene. The basal and upper contacts of the laccolith are porphyritic, with plagioclase crystals as long as $0.5 \mathrm{~cm}$ in a fine-grained or aphanitic matrix. Rocks above laccolith are prominently altered by contact metamorphosed. K-Ar ages

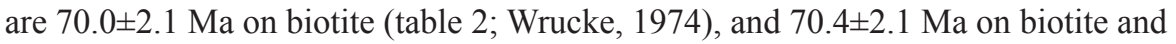
69.4 \pm 2.1 on hornblende (table 2; McDowell, 1971).

Kad Andesite dike (Late Cretaceous?) —Dark-greenish-gray, equigranular andesite dike in the southern Cameron Mountain 7.5' quadrangle that intrudes Paleozoic sedimentary rocks but is truncated by the Late Cretaceous Whitehorn Granodiorite (Wallace and Lawson, 1998). Composed primarily of plagioclase microlites in a chloritic matrix. Dike is about 1-2 $\mathrm{m}$ wide 


\section{PALEOZOIC SEDIMENTARY ROCKS}

PPm Maroon Formation (Lower Permian to Middle Pennsylvanian)—The upper approximate $350 \mathrm{~m}$ consist mainly of reddish-brown, and subordinately gray, gray-green, tan and brownish-tan, siltstone and sandstone; generally more red hues than in lower part. Upper part lacks gypsiferous shale and contains very little calcareous shale. The lower approximate $1,000 \mathrm{~m}$ is composed of pale red, tan, medium-gray, or greenish-gray siltstone, sandstone, shale and gypsiferous shale; siltstone and fine to very-fine sandstone are the most common lithologies (Widman and others, 2011; Houck and others, 2012); shale locally calcareous. Planer laminae, ripple cross-laminae, trough cross-beds, and thin planer beds are locally present. Both upper and lower parts of the Maroon Formation lack limestone beds. An unknown thickness of the Maroon Formation has been eroded from map area. Conformable with underlying Minturn Formation. A detailed discussion of the history of the Permian-Pennsylvanian nomenclature and stratigraphic problems in the northeastern part of the map area is summarized in Houck and others (2012). The Maroon Formation is about 1,610 m thick in the adjoining Garo 7.5' quadrangle (Kirkham and others, 2007)

Pm Minturn Formation (Middle Pennsylvanian) - The upper 550 to $900 \mathrm{~m}$ are similar to the Maroon Formation and consist mostly of thinly bedded and laminated, reddish, and variegated arkosic and micaceous sandstone and siltstone, with minor shale (locally calcareous or gypsiferous) (Houck and others, 2012). Sandstone is mostly fine grained but unit contains local lenses of medium- to coarse-grained sandstone. Calcareous horizons are as thick as $100 \mathrm{~m}$. Common well-indurated siltstones tend to be quartz rich. Ripple cross-lamination, mud cracks, shale rip-up clasts, raindrop impressions, and land-plant debris are particularly common in the calcareous horizons (Widmann and others, 2011). The uppermost approximately $70 \mathrm{~m}$ of the Minturn Formation is composed mostly of calcareous and gypsiferous shale, probably equivalent to the Jacque Mountain Limestone Member, which is the uppermost member of the formation and defined as an oolitic limestone by Tweto and Lovering (1977) near Minturn, about $25 \mathrm{~km}$ north of the map area. Consequently, the top of the unit is defined at the top of the highest calcareous bed. The middle $650-1,000 \mathrm{~m}$ contains the above lithologies in addition to micritic limestone and dolomite beds, gypsiferous shale, and gypsiferous sandstone (Houck and others, 2012). The lower $125 \mathrm{~m}$ typically contains dark-gray shale and fine- to coarse-grained, arkosic, micaceous sandstone; black, phosphatic fish coprolites as long as $2 \mathrm{~cm}$ are locally observed. The lower part in the Marmot Peak 7.5' quadrangle (Houck and others, 2012), and the lowest part immediately above the Belden Formation $(\mathrm{Pb})$ in the Jones Hill 7.5' quadrangle (Widmann and others, 2011) contain quartz-pebble conglomerate, quartzfeldspar sandstone, and interberbedded black shale and thin limestone beds that are laterally equivalent to the Coffman Member of the Minturn, as described near Trout Creek Pass (Gould, 1935; De Voto and Peel, 1972; Wallace and Keller, 2003). The Belden-Minturn contact is drawn at the base of prominent, ridge-forming sandstone overlying the mostly black fissile shale of the Belden. The Belden-Minturn sequence was formerly called the Weber Formation (Emmons, 1898; Behre, 1953)

Pme Evaporite facies-Predominantly light- to medium-gray, gypsiferous and calcareous shale, with minor fine-grained sandstone, limestone, dolomite, and massive gypsum (Houck and others, 2012). Halite may be present in the subsurface. Sandstone beds are less than $0.5 \mathrm{~m}$ thick. Limestone and dolomite beds are medium gray and finely to coarsely crystalline; some contain rounded quartzite and chert clasts that weather out, forming a boxwork appearance. The evaporite facies is locally thickened by folding and faulting, so structural thickness may exceed $600 \mathrm{~m}$ in the northeastern Jones Hill 7.5' quadrangle (Widmann and others, 2011), but generally thins to the south and pinches out into the main body of the Minturn Formation. Poorly exposed in most places. Sinkholes, caused by dissolution of underlying evaporite minerals and collapse of overlying sediments, are common 
Pmc Coffman Member-Light-gray to white, fine-grained to conglomeratic, arkosic quartz sandstone, characterized by beds containing white quartz pebbles less than $5 \mathrm{~cm}$ in maximum dimension, with subordinate amounts of subrounded feldspar and granite pebbles (Widmann and others, 2011). Contains a few interbedded brownish, "dirty," feldspathic and micaceous sandstones. Age is early Atokan (early Middle Pennsylvanian; Houck and others, 2004) and source is to the east from Front Range region, as shown by sparse amazonite clasts (turquoise-colored feldspar from Mesoproterozoic Pikes Peak Granite) (K.J. Houck, Denver Museum of Nature and Science, oral commun., 2012). The top of unit is gradational into the main body of the Minturn Formation, but is defined by the highest white quartz-pebble bed. The base interfingers with and pinches out into either the main part of the lower Minturn or the Belden Formation. Called Coffman Member of the Minturn Formation in the Jones Hill 7.5' quadrangle (Widmann and others, 2011), but does not closely resemble the Coffman Member in its type area in Kaufman Park near Trout Creek Pass (Gould, 1935; he misspelled Kaufman, but the name Coffman was nonetheless retained), and in the Antero Reservoir 7.5' quadrangle to the east (Kirkham and others, 2012), which is largely a sequence of arkosic and micaceous sandstone, conglomerate with some limestone and dark gray to black shale at the base of the Minturn Formation. Maximum thickness is about $200 \mathrm{~m}$, but pinches out in a short distance south of Round Hill, just west of Black Mountain

P€u

$\mathrm{Pb}$

Pbc
Middle and Lower Pennsylvanian, Mississippian, Devonian, Ordovician, and Cambrian rocks, undivided-Mapped in the Leadville region where complex faulting and extensive surficial cover obscure the bedrock geology (Tweto, 1974a, b; new mapping). Includes rocks as young as Middle Pennsylvanian age Belden Formation. Numerous small Tertiary and Late Cretaceous porphyry dikes and sill intrude this unit (Tweto, 1974a) but are not shown on map

Belden Formation (Middle and Lower Pennsylvanian)_-Predominantly dark-gray to black, fissile to massive, locally calcareous and (or) carbonaceous shale, with subordinate limestone, dolomite, and sandstone beds (Widmann and others, 2011; Houck and others, 2012). May contain plant and marine fossils as well as silicified wood. Thin darkgray limestone beds are particularly present in a 6-m-thick interval about $100 \mathrm{~m}$ above base of formation (Newett limestone member of Gould, 1935). Upper contact is placed about $60 \mathrm{~m}$ higher in the section in the north part of the Marmot Peak 7.5' quadrangle as compared with the southern part of that quadrangle (Houck and others, 2012). The Belden Formation is not mapped in the Climax 7.5' quadrangle, although the lower part of the Minturn contains a sequence of black shale and minor sandstone beds (McCalpin, Temple, and others, 2012), probably equivalent to the Belden. Formation is as thick as about 360 m just north of the Buffalo Peaks in the southern Jones Hill 7.5' quadrangle (Widmann and others, 2011), and $230 \mathrm{~m}$ thick in the Fairplay West 7.5' quadrangle (Widmann and others, 2007). Unconformably overlies Leadville Limestone (MI)

Quartz-pebble conglomerate and sandstone member-Light-gray to white and tan, fine-grained to conglomeratic, "clean" arkosic quartz sandstone, characterized by beds containing white quartz pebbles less than $5 \mathrm{~cm}$ in maximum dimension, with subordinate amounts of subrounded feldspar and granite pebbles (Widmann and others, 2011). Contains a few interbedded brownish, silty, feldspathic and micaceous sandstones. Extends from the northern Jones Hill 7.5' quadrangle eastward into the Fairplay West 7.5' quadrangle (Widmann and others, 2007, 2011), where it is interbedded with and largely underlies main body of Belden Formation; not recognized in the Climax 7.5' quadrangle. Source area is considered to the west in the area of the present Sawatch Range (De Voto, 1980). Mapped as Coffman Member of Minturn by Widmann and others (2011), after De Voto and Peel (1972), and does superficially resemble the Coffman Member of the Minturn (Pmc) in the map area, although it is not in the same stratigraphic position. Furthermore, it does not resemble the type Coffman Member as described in the Antero Reservoir 7.5' quadrangle to the east (Kirkham and others, 2012), which is largely a sequence of arkosic and micaceous sandstone, conglomerate with some limestone and dark gray to black shale at the base of the Minturn Formation. Thickness is as much as about $330 \mathrm{~m}$ 
Pk

Dc

Kerber Formation (Lower Pennsylvanian)—Predominantly grayish-green, olive-drab, gray, and dark greenish-gray, medium- to coarse-grained conglomeratic arkose and subordinate medium- to fine-grained arkose, siltstone, shale, and a few interbeds of black shale, siltstone, gray limestone (fossiliferous near top of formation), and rare dolomite. Sandstone beds locally show cross beds, trough cross beds, and cross laminations. Finer grained towards top of sequence, which consists mostly of olive-drab shale and siltstone, black shale, and limestone beds. Unconformably overlies Leadville Limestone, and has a gradational contact with overlying Belden Formation $(\mathbb{P b})$, but the Belden is not mapped in the Salida East 7.5' quadrangle (Wallace and others, 1997). The Kerber Formation is described by De Voto and Peel (1972) as laterally equivalent to at least part of the Belden Formation. Apparently pinches out to the north just south of Triad Ridge. Disconformably overlies Leadville Limestone. As thick as about $335 \mathrm{~m}$ in Salida East 7.5' quadrangle (Wallace and others, 1997)

Leadville Limestone (Lower Mississippian)—Medium-gray to dark-gray, bluish-gray to black, micritic limestone and finely crystalline dolomite with abundant black chert nodules and lenses. Beds are massive and as thick as about $2 \mathrm{~m}$ (thicker than in underlying Dyer Dolomite). Distinctive "zebra rock" in carbonate rocks consists of alternating white and black layers a few mm thick. The Leadville Limestone is locally hydrothermally altered to dolomite, particularly in the Leadville mining district, where it is more properly called Leadville Dolostone (for example, Wallace, 1993; Cappa and Bartos, 2007). Upper surface locally brecciated and forms paleokarst topography with numerous sinkholes and caves. The Leadville Limestone map unit includes the Molas Formation, which is composed chiefly of loessite and associated paleosol that locally fills karst depressions in the Leadville Limestone (Evans and Reed, 2007). The Molas is also mapped near Gilman, just north of the map area (Tweto and Lovering, 1977). The Leadville disconformably overlies the Upper Devonian and Lower Mississippian(?) Dyer Dolomite (Dd). Near Salida; the base of the Leadville consists of shallow channels cut into the Dyer Dolomite and filled with calcite-cemented quartz sandstone, sandy limestone, and flat-pebble conglomerate (Wallace and others, 1997). Total thickness of the Leadville is about $50 \mathrm{~m}$ in the north part of the map area and thickens to as much as $78 \mathrm{~m}$ near Salida (Wallace and others, 1997). The Leadville Limestone pinches out just north of the map area near Hoosier Pass, where the Pennsylvanian Minturn Formation rests unconformably on Devonian rocks of the Chaffee Group (Wallace and others, 2002). Queried where identification is not certain Quartzite of Sheep Mountain-White or light-gray, clean quartz sandstone at the top of the Leadville Limestone that thickens northward from about $6 \mathrm{~m}$ in the Castle Rock Gulch 7.5' quadrangle (Wallace and Keller, 2003) to about $15 \mathrm{~m}$ in the Fairplay West 7.5' quadrangle (Widmann and others, 2007), but apparently pinches out just to the north and is not observed in the Alma 7.5' quadrangle (Widmann and others, 2004). Mapped separately only in the Fairplay West 7.5' quadrangle, where it was informally named (Widmann and others, 2007); elsewhere combined with the Leadville Limestone $(\mathrm{Ml})$

Mississippian? Devonian, Ordovician, and Cambrian rocks, undivided (Mississippian? to Cambrian)-Mapped north of Leadville where complex faulting and extensive surficial cover obscure the bedrock geology (Tweto, 1974a, b; new mapping). Numerous small Tertiary and Late Cretaceous porphyry dikes and sills intrude this unit (Tweto, 1974a) but are not shown on map

Chaffee Group, undivided (Lower Mississippian? and Upper Devonian)—Composed of Dyer Dolomite (Dd) and underlying Parting Sandstone (Dp). Undivided Chaffee Group is found in most places where units are poorly exposed or too thin to map separately. Dyer Dolomite and Parting Sandstone mapped separately south of Buffalo Peaks in Marmot Peak 7.5' quadrangle (Houck and others, 2012) and locally in Fairplay West 7.5' quadrangle, just north of Round Mountain (Widmann and others, 2007)

Dyer Dolomite (Lower Mississippian? and Upper Devonian)—Thinly bedded to massive, finely crystalline and microcrystalline dolostone; Upper two-thirds medium gray; lower third slightly lighter gray. Dolostone weathers to a distinctive yellowish to brownish-yellow, soft surface. Locally contains thin shale lenses and chert 
nodules. Average thickness in the Jones Hill 7.5' quadrangle about $24 \mathrm{~m}$ (Widmann and others, 2011), but apparently thickens to the south; about $36 \mathrm{~m}$ thick in Marmot Peak 7.5' quadrangle (Houck and others, 2012) and reported about $75 \mathrm{~m}$ thick in Cameron Mountain 7.5' quadrangle to south (Wallace and Lawson, 1998). The Lower Mississippian Gilman Sandstone, which overlies the Dyer north of map area, has not been identified in the mapped area. Basal contact with underlying Parting Sandstone is gradational and conformable (Chronic, 1964)

Parting Sandstone (Upper Devonian) — Light gray to bright white, fine- to mediumgrained, well-sorted, quartz arenite, interbedded with moderately well-sorted, tan dolomitic sandstone. Locally coarse grained and contains quartz pebbles, especially near base. Finer-grained and dolomitic sandstone weathers orange-brown, whereas coarsergrained sandstone weather gray to purple. Generally is not as clean or white as Sawatch Quartzite. Unit Dp is about $35 \mathrm{~m}$ thick in the Jones Hill 7.5' quadrangle (Widmann and others, 2011), less than $20 \mathrm{~m}$ thick in Marmot Peak 7.5' quadrangle (Houck and others, 2012), and only about $9 \mathrm{~m}$ thick near Leadville (Behre, 1953). Reported about $15 \mathrm{~m}$ thick in the Cameron Mountain 7.5' quadrangle (Wallace and Lawson, 1998). Unconformably overlies either Ordovician or Cambrian rocks

Or

Ofh

Of

Oh

$\mathrm{Om}$

O€m
Ordovician rocks, undivided-Mapped only in large fault-bounded blocks or patches of Ordovician rock (interpreted as slide blocks) overlying hornblende gneiss and amphibolite in Maysville 7.5' quadrangle near south map boundary (Shannon and McCalpin, 2006). Probably mostly if not entirely Manitou Dolomite (Om)

Fremont Dolomite and Harding Sandstone, undivided (Upper and Middle Ordovician)-Mapped in numerous locations where outcrop width of individual units too thin to show separately

Fremont Dolomite (Upper Ordovician)—Gray, medium-crystalline, massive dolostone and sandy dolostone in beds up to several $\mathrm{m}$ thick; sparsely fossiliferous. Reddishbrown alteration zone at base, with boxwork-like structure. Weathers yellowish gray. Generally poorly exposed, but well exposed on Trout Creek Pass. Contact with underlying Harding Sandstone (Oh) disconformable. As thick as about $35 \mathrm{~m}$ in southern part of Marmot Peak 7.5' quadrangle (Houck and others, 2012), but pinches out to north about $0.5 \mathrm{~km}$ north of Salt Creek; outcrop extends south out of map area

Harding Sandstone (Middle Ordovician)—Reddish-brown, white, orange, purple, silicacemented fine- to coarse-grained quartz sandstone. Intermittent basal breccia zone contains chert clasts as long as $8 \mathrm{~cm}$. Locally forms small ridge or hogback between less resistant Fremont Dolomite (Of) and Manitou Dolomite. Basal contact is disconformable. Locally contain fish plates. About $25 \mathrm{~m}$ thick south of Buffalo Peaks, but reported to pinch out just north of the peaks (Chronic, 1958). Houck and others (2012) did not map the Harding Sandstone in the Marmot Peak 7.5' quadrangle

Manitou Dolomite, upper part (Lower Ordovician) - Gray to light tan, locally mottled, fine- to medium-crystalline, thin to thickly bedded, dolostone and rare beds of darkgray limestone; locally fossiliferous (crinoids, gastropods, echinoderms, nautiloids, and trilobite fragments) (Houck and others, 2012). Lower third of formation contains mostly white, but also gray and black chert nodules, lenses, and layers; very sparse white chert in upper part of formation. In the Buena Vista East 7.5' quadrangle (Keller and others, 2004), and in quadrangles to the south, the Upper Cambrian Dotsero Formation (Myrow and others, 2003) is not recognized and the Manitou is described as disconformably overlying the Upper Cambrian Sawatch Quartzite. The Lower Ordovician part of the Manitou Dolomite is mapped south of the Buffalo Peaks, where the Upper Cambrian Taylor Pass Member of Manitou Dolomite (Myrow and others, 2003) may have been eroded before deposition of the upper part of the Manitou or was never deposited. Thickness is about $65 \mathrm{~m}$

Manitou Dolomite, including Upper Cambrian Taylor Pass Member of Myrow and others (2003) (Lower Ordovician and Upper Cambrian)—Gray to light tan, locally mottled, fine- to medium-crystalline, thin to thickly bedded, dolostone and rare beds of dark-gray limestone; locally fossiliferous (crinoids, gastropods, echinoderms, nautiloids, and trilobite fragments). Lower part contains mostly white, but also gray 
and black chert nodules, lenses, and layers; very sparse white chert in upper part of formation. Contains flat-pebble (limey mudstone clasts) conglomerate (Widmann and others, 2011), just above Upper Cambrian Taylor Pass Member of the Manitou Dolomite of Myrow and others (2003). The Taylor Pass Member has an upper, resistant, purple-tinged dolomite overlying dark-red shale; the member was historically called the "red-cast beds" (Emmons and others, 1886), and was formerly considered the upper part of the shaly Peerless Formation (Behre, 1953; Tweto, 1974a). The Taylor Pass Member pinches out southward beneath the Buffalo Peaks, so the Upper Cambrian beds of the Manitou are mapped only north of the Buffalo Peaks (Widmann and others, 2011; Houck and others, 2012; Tweto, 1974a; Bohannon and Ruleman, 2013). Has disconformable contact with underlying Dotsero Formation (described below as part of unit $€ d s$ ). About $65 \mathrm{~m}$ thick (Upper Cambrian), undivided-Undivided unit mapped in and south of Buena Vista East 7.5' quadrangle (McCalpin and Shannon, 2005), where outcrops of Sawatch Quartzite are generally too thin to show separately. Manitou Dolomite in this area is entirely Ordovician in age (does not contain the Upper Cambrian Taylor Pass Member) and the description follows that outlined in unit O€m above.

The Sawatch Quartzite consists of white to pale pink, fine- to medium-grained, well-sorted, very resistant quartz arenite, interbedded with subordinate reddishpurple, fine-grained, well-sorted feldspathic and locally glauconitic quartz sandstone. Beds typically are 1-3 m thick. Basal, thin (less than $0.5 \mathrm{~m}$ thick) quartz-pebble conglomerate rests unconformably on Proterozoic rocks. Locally contains prominent vertical Skolithos (worm) burrows. Not mapped in Garfield 7.5' quadrangle (Dings and Robinson, 1957) in southwestern corner of map area, where Manitou Dolomite overlies Proterozoic rocks. Only about 4-5 m thick in southern part of Marmot Peak (Houck and others, 2012) and Buena Vista East 7.5' (Keller and others, 2004) quadrangles, but thickens dramatically immediately north of Buffalo Peaks, where it is about $54 \mathrm{~m}$ thick (Widmann and others, 2011); it is about $20 \mathrm{~m}$ thick in the Leadville area (Behre, 1953). North of the Buffalo Peaks, the Sawatch Quartzite is combined with the Upper Cambrian Dotsero Formation, described below. The Sawatch pinches out in the eastern Buena Vista East 7.5' quadrangle (Keller and others, 2004) near Trout Creek Pass, and is not recognized in the Castle Rock Gulch 7.5' quadrangle (Wallace and Keller, 2003), where Manitou Dolomite overlies Proterozoic granitic rock. The Sawatch reappears to the south in northern Cameron Mountain 7.5' quadrangle (Wallace and Lawson, 1998) and forms an almost continuous outcrop to the south where it is as thick as $8 \mathrm{~m}$ but is mostly less than $3 \mathrm{~m}$ thick; it apparently disappears in a small area just north of Salida (Wallace and others, 1997). The Sawatch Quartzite is not mapped separately, but is combined with either the Manitou Dolomite (unit O€ms) or the Upper Cambrian Dotsero Formation (unit $€ d s$ ) Dotsero Formation consists of an upper $\sim 10 \mathrm{~m}$ of purplish-tan, thin-bedded, shaly, glauconitic, dolomitic sandstone, and a lower $\sim 5 \mathrm{~m}$ of reddish-purple cliff-forming fine- to medium-grained quartz sandstone (Red Cliff and Sheep Mountain Members of the Dotsero Formation, respectively, of Myrow and others, 2003, although these two names were formally used for other rock units elsewhere in Colorado prior to their use by Myrow and others, 2003). The Dotsero is not recognized south of the Marmot Peak 7.5' quadrangle (Houck and others, 2012).

The description of the Sawatch Quartzite is given above in the unit O€ms. The Sawatch is combined with the Dotsero Formation in the Jones Hill (Widmann and others, 2011) and Marmot Peak (Houck and others, 2012) 7.5' quadrangles, where most of the Sawatch outcrops are too thin to map separately. The Sawatch Formation, as mapped by Tweto (1974a) in the Leadville area, includes the recently recognized Dotsero Formation, and so is shown in this area as Dotsero Formation and Sawatch Quartzite, undivided 


\section{PROTEROZOIC ROCKS}

\section{INTRUSIVE ROCKS}

Yla Lamprophyre and andesite dikes (Mesoproterozoic?)-Lamprophyre dikes are fine- to medium-grained, mostly dark-greenish-gray, $1-2 \mathrm{~m}$ thick porphyritic dikes composed primarily of plagioclase in a chloritic matrix with mostly hornblende and biotite phenocrysts. Generally west-trending and intrude Mesoproterozoic rocks (primarily Elephant Rock Granite: Yge). Called "dacite dikes" in Buena Vista East 7.5' quadrangle by Keller and others (2004), but are continuous with lamprophyre dikes to the south (Van Alstine and Cox, 1969), and with "andesite dikes" to the east (Wallace and Lawson, 1998), where porphyritic texture not recognized. Unit also includes "andesite hybrid dikes" that cut Paleoproterozoic rocks in the southern part of the Maysville 7.5' quadrangle (Shannon and McCalpin, 2006). These are highly variable, medium gray to dark gray, locally greenish, fine grained equigranular to porphyritic dikes with relict phenocrysts of hornblende, pyroxene, and olivine(?). Tentatively interpreted by us as Mesoproterozoic in age, although Shannon and McCalpin (2006) suggest that lack of metamorphic fabric indicates they may be as young as Tertiary

YXp Pegmatite (Mesoproterozoic and Paleoproterozoic) —Coarse-grained to very coarse grained, white to light-pink, inequigranular quartz-feldspar-mica rock that forms irregularly shaped, commonly zoned dikes and intrusive bodies cutting all Proterozoic rocks in map area. Microcline crystals may be longer than $0.5 \mathrm{~m}$ in some pegmatites; mica is mostly biotite, but locally includes or is entirely muscovite. Accessory minerals include tourmaline, garnet, and opaque minerals. Unit consists predominantly of pegmatite, which commonly grades into (and is intimately mixed with) aplite that forms separate dikes and bodies. Aplite is similar in composition to pegmatite but is a pinkish-tan, fine- to medium-grained, leucocratic, equigranular rock. Pegmatite and aplite are late-stage intrusions associated with rocks of either Paleoproterozoic Routt Plutonic Suite (about 1,700 Ma) or Mesoproterozoic Berthoud Plutonic Suite (about 1,400 Ma) of Tweto (1987), although most pegmatites in map area are probably related to late stages of the Berthoud Plutonic Suite. Mapped only in a few places, although common at larger scales

YXgr Granitic rock, undivided (Mesoproterozoic or Paleoproterozoic)—Undated small plutons and dikes in relatively small, scattered localities, both in the Sawatch Range and Mosquito Range. Generally light-gray to medium-gray, medium-grained, massive to weakly foliated biotite monzogranite and granodiorite

YXhm Hornblende monzodiorite (Mesoproterozoic or Paleoproterozoic)—Dark-gray, medium-grained, equigranular to porphyritic, massive to weakly foliated, with plagioclase phenocrysts as long as $1 \mathrm{~cm}$; ranges from monzodiorite to quartz monzodiorite. Mineral content is about 3-6 percent quartz, 30 percent plagioclase, 20 percent microcline, 20-40 percent hornblende, 5 percent biotite, 1-3 percent sphene, 1 percent trace amounts of apatite, zircons, and opaque minerals. Forms one body between Elephant Rock Granite and Langhoff Gulch Granite, in and near headwaters of Rock Creek in Harvard Lakes 7.5' quadrangle (Kellogg and others, 2013), just east of Riverside. It is unclear whether it is an older block intruded by Mesoproterozoic granite or it intruded surrounding granite

YXhd Hornblende diorite (Mesoproterozoic or Paleoproterozoic)—Dark-green to dark gray, fine-grained to medium-grained, hornblende-rich diorite (Tweto, 1974a). Forms isolated plutonic bodies along East Fork Homestake Creek and scattered dikes in the map area. Unit is cut by lamphrophyre dikes (not shown on map) that also cut St. Kevin Granite (Ygs). Tweto (1974a) also noted that the unit is probably related to small hornblendite pods (not shown) localized around shear zones. Not dated

Ygdh Granodiorite of Mount Harvard (Mesoproterozoic)—Gray, medium-grained to coarsegrained, equigranular to porphyritic, weakly foliated biotite granodiorite at and near Mount Harvard. Composed, in decreasing amounts, of sodic plagioclase, perthite, quartz, biotite, chloritized biotite, opaque minerals, and minor amounts of apatite and 
zircon (Fridrich and others, 1998). Previously mapped as Paleoproterozoic Denny Creek Granite (Fridrich and others, 1998), but new U-Pb zircon age of 1,414 $\pm 20 \mathrm{Ma}$ (location O, table 2; Moscati and others, 2017) indicates that this pluton is of Mesoproterozoic age

Ygl Langhoff Gulch Granite (Mesoproterozoic)—Gray, medium-grained, equigranular to inequigranular, massive to weakly flow-foliated, syenogranite, monzogranite, and granodiorite; mostly monzogranite. Contains about 25-35 percent quartz, 20-40 percent plagioclase, 12-45 percent microcline, 4-20 percent biotite, 1-2 percent muscovite, trace to 1 percent sphene, and trace amounts of zircon and apatite; locally contains sparse rutile and garnet. Almost all modal analyses from 19 stained slabs indicate monzogranite composition (fig. 10). Unit typically weathers to distinctive reddish-brown to light grayish-brown rounded to blocky outcrops. Langhoff Gulch, for which unit is formally named, is located in $\mathrm{NE}^{1} / 4 \mathrm{sec}$. 31, T. $12 \mathrm{~S}$., R. $79 \mathrm{~W}$., about $7 \mathrm{~km}$ southeast of the town of Granite. Dikes and bodies of rock included with Langhoff Gulch Granite intrude Elephant Rock Granite (Yge) in many places, such as small stocks of massive to foliated, generally gray to pinkish-gray, medium-grained monzogranite and subordinate quartz monzonite in Buena Vista East 7.5' quadrangle (Keller and others, 2004). New U-Pb zircon age from location U is 1,441 $\pm 54 \mathrm{Ma}$ (Moscati and others, 2017). The name Langhoff Gulch Granite is herein formalized and location U on map (38 $59^{\prime} 17^{\prime \prime N}$., $106^{\circ} 12^{\prime} 45^{\prime \prime} \mathrm{W}$., on the USGS Harvard Lakes 7.5' quadrangle), in a small abandoned quarry near the mouth of Langhoff Gulch, is hereby designated the type locality. The Langhoff Gulch Granite at two other locations has $\mathrm{U}-\mathrm{Pb}$ zircon ages of $1,435 \pm 26 \mathrm{Ma}$ and $1,438 \pm 11 \mathrm{Ma}$ (locations $\mathrm{S}$ and $\mathrm{V}$ respectively, table 2; Moscati and others, 2017). Unit includes granitic rocks in Climax 7.5' quadrangle (McCalpin, Temple, and others, 2012) that are "similar in texture and composition" to the 1,442 \pm 2 Ma Silver Plume Granite (Graubard and Mattison, 1990), which is exposed about $50 \mathrm{~km}$ northeast of the map area

Strongly foliated facies-Bodies of strongly foliated Langhoff Gulch Granite intrude and are interlayered with biotite gneiss $(\mathrm{Xb})$. Rock is gray, medium-grained, strongly foliated and locally forms zones of augen gneiss. Mapped in one area just east of Arkansas River, east of Lake Creek massive to moderately foliated, porphyritic monzogranite and subordinate granodiorite (fig. 11). In the Harvard Lakes 7.5' quadrangle, unit contains about 30-35 percent quartz, 25-30 percent plagioclase (oligoclase), 30-32 percent microcline, 6-12 percent biotite, 1-2 percent sphene, and trace amounts of apatite, zircon, and opaque minerals (Kellogg and others, 2013). Microcline phenocrysts are as long as $3 \mathrm{~cm}$. Commonly weathers into distinctive rounded, reddish-brown tors with intervening areas of reddish-brown grus. Forms large batholith east of Arkansas River that extends from the northern Harvard Lakes 7.5' quadrangle (Kellogg and others, 2013) as far south as the northern Salida East 7.5' quadrangle (Wallace and others, 1997), a distance of about $42 \mathrm{~km}$. Referred to as "granodiorite" several quadrangles south of Harvard Lakes 7.5' quadrangle. Unit includes numerous outcrops of similar coarse-grained granite interpreted as blocks incorporated into Langhoff Gulch Granite (Ygl) in South Peak 7.5' quadrangle. Formerly suspected to be equivalent to Paleoproterozoic Henry Mountain Granite near Gunnison (DeWitt and others, 2010), but a U-Pb zircon age from about $4 \mathrm{~km}$ north of Buena Vista in an abandoned train tunnel just south of a pinnacle named Elephant Rock, located atNE1/4 sec. 31, T. 13 S., R. 78 W. and composed of Elephant Rock Granite is 1,436 $\pm 8 \mathrm{Ma}$ (location X, table 2; Moscati and others, 2017). A U-Pb date from a roadcut on Highway 285 east of Buena Vista is 1,434 \pm 8 Ma (location W, table 2; Moscati and others, 2017). The name Elephant Rock Granite is herein formalized and location X $\left(38^{\circ} 52^{\prime} 38^{\prime \prime} \mathrm{N}\right.$., $106^{\circ} 08^{\prime} 44^{\prime \prime} \mathrm{W}$. on the USGS Harvard Lakes 7.5' quadrangle) is hereby designated as the type locality

Ygef Strongly foliated facies-Gray, well-foliated equigranular to porphyritic, biotiteplagioclase-microcline-biotite gneiss. Augen gneiss in most places, with microcline 
Yhy

augens as long as $3 \mathrm{~cm}$. Represents highly strained facies of Elephant Rock Granite.

Interlayered in some places with biotite gneiss

Hybrid mix of Langhoff Gulch Granite and Elephant Rock Granite (Mesoproterozoic) -

Mapped where Langhoff Gulch Granite and Elephant Rock Granite are intimately intermixed. Langhoff Gulch Granite intruded or partially assimilated Elephant Rock Granite, indicating that it is slightly younger; isotopic ages are identical within experimental uncertainly. Contacts are sharp in some places and gradational in others, indicating similarity in age

Ybp Browns Pass Granite of Fridrich and others (1998) (Mesoproterozoic) — Light-tan, medium-grained, equigranular, undeformed, leucocratic biotite-muscovite monzogranite and aplite mapped on east slope of Mount Yale. Originally named Browns Pass Quartz Monzonite (Barker and Brock, 1965), but new chemical and petrographic data indicate monzogranite composition (Fridrich and others, 1998). New U-Pb zircon age from about $3 \mathrm{~km}$ west of Mount Yale is 1,439 $\pm 11 \mathrm{Ma}$ (table 2, Moscati and others, 2017), in agreement with older K-Ar age of 1,420 $35 \mathrm{Ma}$ (table 2; Wetherill and Bickford, 1965)

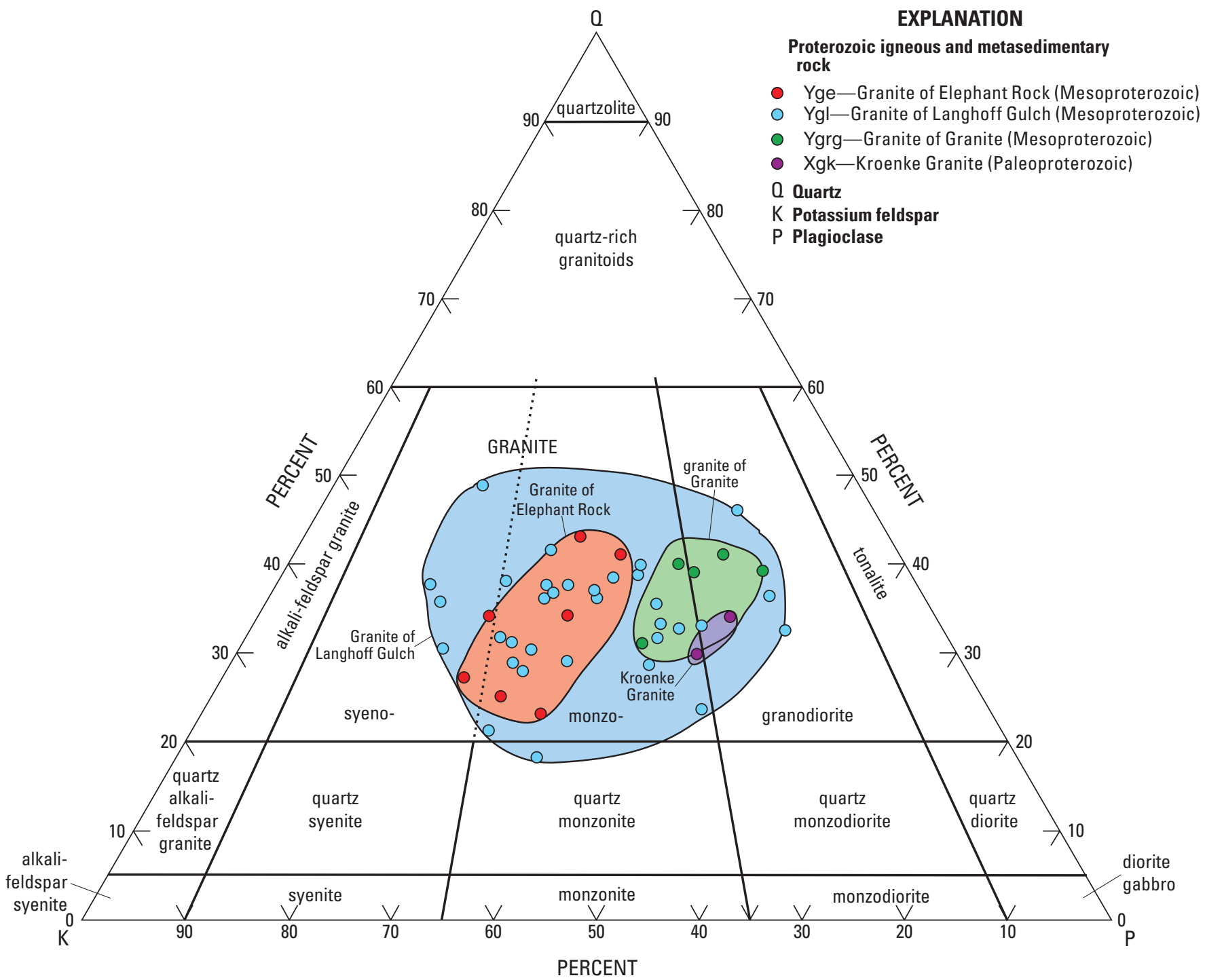

Figure 11. Ternary diagram with quartz ( $Q)$, potassium feldspar (K), and plagioclase $(P)$ at apices, showing modal analysis and approximate fields for Proterozoic rocks including: Mesoproterozoic Langhoff Gulch Granite (Ygl), blue field; granite of Granite (Ygrg), green field; Elephant Rock Granite (Yge), pink field; and Paleoproterozoic Kroenke Granite (Xgk), purple field. Classification of igneous rocks is based on the International Union of Geological Sciences (IUGS) classification (Le Bas and Streckeisen, 1991). 
Ygrg Granite of Granite (Mesoproterozoic)—Medium- to dark-gray to grayish-pink, coarsegrained, massive to moderately foliated monzogranite and granodiorite (fig. 10); locally porphyritic, with potassium feldspar phenocrysts as long as about $3 \mathrm{~cm}$. Tends to be more mafic to west, where rock grades from monzogranite into granodiorite, formerly interpreted as Paleoproterozoic Denny Creek Granodiorite (Xdk) (Fridrich and others, 1998). U-Pb zircon (SHRIMP) age from area previously mapped as Denny Creek Granodiorite (Fridrich and others, 1998) is 1,434 4 Ma (location R, table 2), statistically identical to an age from a monzogranite sample collected from an outcrop near the town of Granite of 1,429 $\pm 9 \mathrm{Ma}$ (location Q, table 2; Moscati and others, 2017; and herein designated as a reference locality for the granite of Granite); consequently, large areas in map area formerly called Denny Creek Granodiorite are now mapped as Mesoproterozoic granite of Granite

Ygdm Granodiorite of Mount Elbert (Mesoproterozoic)—Dark-gray, coarse-grained, equigranular to weakly foliated, biotite-rich granodiorite on the southeastern side of Mount Elbert. Strongly resembles 1,710 Ma Denny Creek Granodiorite, but U-Pb zircon age is $1,415 \pm 15 \mathrm{Ma}$ (location P, table 2; Moscati and others, 2017), similar to age of granite of Granite, phases of which it also resembles; further study is necessary, however, to determine if granodiorite of Mount Elbert and granite of Granite are derived from the same source

Yqd Quartz diorite (Mesoproterozoic)—Dark- to medium-gray, medium to coarse grained, equigranular to weakly porphyritic rock composed of plagioclase (oligoclase-andesine), hornblende, biotite, and minor quartz and microcline (Keller and others, 2004).

Generally has a "salt-and-pepper" appearance. Locally displays primary flow foliation. Contact relationships with Elephant Rock Granite are "ambiguous" (Keller and others, 2004), and the two units may be comagmatic. Forms small east- to northeasttrending lensoid bodies in Elephant Rock Granite in Buena Vista West 7.5' quadrangle (McCalpin and Shannon, 2005) and Buena Vista East 7.5' quadrangle (Keller and others, 2004), and as several bodies in southeastern Harvard Lakes 7.5' quadrangle (Kellogg and others, 2013). All considered to be Mesoproterozoic in age

Ygm Granite of Music Mountain (Mesoproterozoic)—Pink to light-gray, medium grained, locally porphyritic, typically containing quartz, sub-equal amounts of plagioclase and potassium-feldspar, biotite, and accessory sphene, zircon, apatite, and opaque minerals; feldspar phenocrysts are as long as $2.5 \mathrm{~cm}$. Granite of Music Mountain was called "Silver Plume Granite" by Dings and Robinson (1957) due to its similarity to the Silver Plume Granite of the Front Range, but U-Pb zircon age is 1,441 $\pm 9 \mathrm{Ma}$ (Kellogg and others, 2017), which is slightly older than $1,422 \pm 2$ Ma Silver Plume Granite (Graubard and Mattison, 1990). Mapped primarily in the Garfield 7.5' quadrangle (Dings and Robinson, 1957)

Ygs St. Kevin Granite (Mesoproterozoic)—Fine-grained to medium-grained, gray to light pinkish gray, equigranular to porphyritic, massive to locally weakly foliated biotitemuscovite monzogranite or quartz monzonite. Displays a wide variety of textures, including a fine-grained facies, a "normal facies" (medium-grained, equigranular to porphyritic 2-mica monzogranite), a granodiorite facies, and a tracytoid hybrid facies containing close-packed aligned microcline crystals (Tweto, 1974a). Forms a batholith about $40 \mathrm{~km}$ long and $20 \mathrm{~km}$ wide with intricate boundaries, of which only the eastern part is within the map area. U-Pb zircon age is $1,425 \pm 12 \mathrm{Ma}$ (location T, table 2; Moscati and others, 2017)

Xgk Kroenke Granite (Paleoproterozoic)—Medium-gray to dark gray, medium-grained, equigranular, massive to moderately foliated, relatively leucocratic monzogranite and granodiorite (two modal analyses shown in fig. 10). Called Kroenke Granodiorite by Fridrich and others (1998). Locally shows compositional layering defined by biotiterich and biotite-poor rock. Intrudes Denny Creek Granodiorite (Xdk), and granite of Mount Yale (Xgy). Rb-Sr model age from west of map area is 1,670 $\pm 100 \mathrm{Ma}$ (Barker and others, 1974; recalculated in Fridrich and others, 1998), and U-Pb sphene age is $1,645 \pm 5 \mathrm{Ma}$ (Fridrich and others, 1998). More recently, Moscati and others (2017) have a U-Pb zircon age from just west of map area of 1,681 $15 \mathrm{Ma}$ 
Xgy Granite of Mount Yale (Paleoproterozoic) - Light-gray to white, fine- to coarse-grained, equigranular to porphyritic, massive to moderately foliated, leucogranite or alaskite (Fridrich and others, 1998); composition varies from granite to granodiorite. May also be interlayered with biotite gneiss unit (Xb) east of Mount Yale. Granite of Mount Yale is intruded by Denny Creek Granodiorite (Xdk) and Kroenke Granodiorite (Xgk). New $\mathrm{U}-\mathrm{Pb}$ zircon age is $1,695 \pm 11 \mathrm{Ma}$ (location $\mathrm{Y}$, table 2; Moscati and others, 2017)

Xdi Diorite (Paleoproterozoic) —Dark-gray to gray, medium-grained, equigranular, massive to moderately foliated, biotite quartz diorite and biotite diorite. Contains as much as 40 percent biotite and a few percent hornblende. Mapped only in two small areas in Pine Creek in Harvard Lakes 7.5' quadrangle (Kellogg and others, 2013)

Xgd Henry Mountain? Granite (Paleoproterozoic)-Medium-gray to grayish-pink, coarsegrained, massive to strongly foliated monzogranite and granodiorite; locally porphyritic, with potassium feldspar phenocrysts as long as about $3 \mathrm{~cm}$. Strongly resembles Elephant Rock Granite east of Arkansas River, but U-Pb zircon ages from two sites are 1,672 $\pm 5 \mathrm{Ma}$ (location AA, table 2; ID-TIMS age of Bickford and others, 1989) and 1,709 $\pm 6 \mathrm{Ma}$ (location BB, table 2; Moscati and others, 2017). Henry Mountain Granite (1,711 $\pm 9 \mathrm{Ma}$; Moscati and others, 2017) near Gunnison is compositionally, petrographically, and isotopically very similar. Due to similarity to Elephant Rock Granite (Yge), contact between the two units has not been identified and is very approximate (indicated by queried contact). Similar rock tentatively interpreted as Henry Mountain Granite is also mapped in southwestern corner of map area, north and south of South Fork Arkansas River

Xdk Denny Creek Granodiorite (Paleoproterozoic)—Dark gray, coarse-grained, equigranular to porphyritic, massive to strongly tectonically foliated, biotite-rich granodiorite and monzodiorite (Fridrich and others, 1998). Consists, in decreasing amounts, of oligoclase, quartz, perthite, biotite, ilmenite, magnetite, minor amounts of sphene, apatite, allanite, zircon, and chlorite. Originally called Denny Creek Granodiorite Gneiss (Barker and Brock, 1965). Two U-Pb zircon ages are 1,710 $\pm 10 \mathrm{Ma}$ (table 2, from west of map area) and 1,691 $\pm 5 \mathrm{Ma}$ (location Z, table 2; Moscati and others, 2017). Paleoproterozoic Kroenke Granite (Xgk) cuts Denny Creek Granodiorite (Fridrich and others, 1998). Strongly resembles relatively mafic western facies of granite of Granite (Ygrg), although the latter is $\sim 250 \mathrm{my}$. younger. This ambiguity has resulted in an uncertain contact between Denny Creek Granodiorite and granite of Granite

Xgdm Granodiorite of Methodist Mountain (Paleoproterozoic)—Medium-gray, fine- to medium-grained granodiorite. Small intrusive body exposed along the Arkansas River in Salida East 7.5' quadrangle (Wallace and others, 1997). Undated, but assumed by Wallace and other (1997) to be Paleoproterozoic

Xgg Foliated granodioritic augen gneiss and granitic gneiss (Paleoproterozoic)—Light-gray to medium-gray, strongly foliated, medium-grained to very coarse-grained augen gneiss of monzogranite or granodiorite composition. Forms a northeast-trending, 6-km-long body on the southeast slopes of Mount Shavano (Shannon and McCalpin, 2006), and several bodies interlayered with or adjacent to biotite gneiss in the Sawatch Range and east of the Arkansas River in the South Peak 7.5' quadrangle. Commonly interlayered with biotite gneiss $(\mathrm{Xb})$ and intimately intruded by Mesoproterozoic granitic rock. Undated, but similar rocks in the Front Range region have been dated to between about 1,750 and 1,770 Ma (Kellogg and others, 2008, 2011)

Xlg Leucogranite gneiss (Paleoproterozoic) — Light-gray to almost white, medium-grained, moderately foliated monzogranite or granodiorite orthogneiss, with less than 5 percent biotite. Foliation strikes east-northeast. Mapped in small area in Granite 7.5' quadrangle (Shroba and others, 2014)

Xgb Gabbro (Paleoproterozoic)-Mapped in two areas north of the Gunnison-Salida volcanoplutonic belt, where metagabbro sills (Xgs) are mapped separately: (1) in Mount Harvard and Mount Yale 7.5' quadrangles, large inclusions in granite of Mount Yale (Xgy) are dark-greenish black, medium- to coarse-grained, equigranular to slightly foliated hornblende gabbro and diorite; contain mostly plagioclase and hornblende in a finer-grained matrix of hornblende, biotite, quartz, and minor amounts of allanite, sphene, and opaque minerals (Fridrich and others, 1998), and (2) one small area in 
Granite 7.5' quadrangle composed of very dark-green hornblende-biotite gabbro containing about 50 percent medium-grained, calcic plagioclase, hornblende, and biotite in a dark-green, chert-like (serpentinized?) matrix; interpreted as block incorporated along contact between granite of Granite (Ygrg) and unnamed monzogranite (YXgr)

\section{PALEOPROTEROZOIC ROCKS OF THE GUNNISON-SALIDA VOLCANO-PLUTONIC BELT}

Xgs Metagabbro of the Gunnison-Salida volcano-plutonic belt—Dark greenish-gray to black, medium- to coarse-grained hornblende gabbro; composed mostly of plagioclase (labradorite), hornblende (after pyroxene), trace amounts of opaque minerals, and chlorite and epidote locally formed as alteration products; associated with metabasalt (Xba) and intrusive as sills into metavolcanic and metasedimentary rocks units (Xvs and Xms). Mapped in Salida East 7.5' quadrangle (Boardman, 1976; Wallace and others, 1997) and small areas in eastern Salida West 7.5' quadrangle (Van Alstine, 1974)

Xba Metabasalt-Relatively low-grade (greenschist facies) rocks, in which many primary features, such as vesicles, phenocrysts, brecciation, agglomerate, and pillows are preserved, mapped in the northern Salida East 7.5' quadrangle (Boardman, 1976; Wallace and others, 1997). These rocks are dark-gray to black, predominantly aphanitic to fine-grained metabasalt, composed of approximately 50 percent sericitized plagioclase, 40 percent hornblende after pyroxene, 10 percent fine-grained chlorite (after secondary biotite?), and trace amounts of opaque minerals and secondary epidote; contains rare quartz xenocrysts. Commonly interbedded with fine- to coarse-grained metasedimentary rocks

Xvs Metavolcanic rocks, metasedimentary rocks, and metagabbro sills, undivided-Consist of interbedded tan, dark-gray, and black amphibolite, interbedded biotite-rich gneiss and schist, quartzite, and calc-silicate gneiss intruded by numerous metagabbroic sills; larger metagabbro sills are mapped separately (unit Xgs). In the Salida East 7.5' quadrangle, the metasedimentary rocks consist of medium-gray to black, light-gray, and grayish-tan, fine- to very fine-grained, metasiltstones, metagraywackes, and quartzite (Boardman, 1976; Wallace and others, 1997). Where visible, relict bedding is parallel to foliation. Volcanic protoliths are a bimodal assemblage of dacitic to rhyolitic volcanic rocks and basalt flows. The metagabbro sills appear as poorly foliated amphibolite in the south part of the map area. Foliation increases abruptly northward in all rocks of the map unit, and in the northern Salida East and Salida West 7.5' quadrangles relict sedimentary and volcanic structures are no longer discernable, apparently due to the effects of the large granitic intrusion just north of the sequence (Boardman, 1976). Metamorphic grade also increases northward, such that sillimanite replaces biotite and muscovite in pelitic rocks (Boardman, 1976). Also mapped extensively in the southern Maysville 7.5' quadrangle (Shannon and McCalpin (2006). Unit is mapped where metavolcanic and metasedimentary units are generally too thin to map separately. Contains a quartzite layer (qc) at two localities in southern Maysville 7.5' quadrangle that is interpreted as a metachert (Shannon and McCalpin, 2006). U-Pb zircon (SHRIMP) dates on metadacite samples near Salida are 1,732 \pm 4 Ma (location CC, table 2; Kellogg and others, 2017) and 1,728 $\pm 6 \mathrm{Ma}$ (location DD, table 2; Bickford and others, 1989). These ages indicate that these rocks correlate with the younger $(1,730-1,740 \mathrm{Ma})$ of two metavolcanic sequences exposed closer to Gunnison (Bickford and others, 1989) in the southern Maysville 7.5' quadrangle (Shannon and McCalpin, 2006) and a large area within $15 \mathrm{~km}$ north of Salida, east of the Arkansas River. Includes biotite gneiss, muscovite schist, biotite-muscovite schist, calc-silicate gneiss, quartzite, muscovitesillimanite gneiss, and muscovite-cordierite schist (larger bodies of the latter unit mapped separately as Xmc). Rocks of unit Xms are interlayered with minor, unmapped, thin beds of metavolcanic rocks and locally intruded by small, unmapped bodies of gabbro and granitic rocks. Biotite gneiss is similar to that described separately north of the Gunnison-Salida volcano-plutonic belt and is commonly migmatitic. Muscovite schist is light tannish white to medium gray, fine to medium grained, moderately to strongly foliated and contains quartz, feldspar, and abundant muscovite. Muscovite-sillimanite 
schist is almost white to light-orange-brown, fine- to medium-grained and characterized by small "eyes" of sillimanite-quartz-muscovite as long as $2 \mathrm{~cm}$. Calc-silicate gneiss is exposed in narrow zones generally associated with amphibolitic rocks and consists of greenish-gray to black, light-orange to reddish weathering, fine- to coarse-grained assemblages of clinopyroxene (diopside-hedenbergite), amphibole (tremolite-actinolite), biotite, garnet, chlorite, carbonate, epidote, and sphene. Rock generally non-foliated, except for mica-rich varieties. Some calc-silicate rocks have associated with zinc, copper and lead mineralization. Quartzite (qz) is a very distinctive rock type mapped in the southern Maysville 7.5' quadrangle (Shannon and McCalpin, 2006) consisting of light- to dark-gray, very fine- to fine-grained quartz-magnetite-hematite rock. Quartzite beds are as thick as $8 \mathrm{~m}$ and hundreds of meters long. They are mostly massive, but locally have remnant bedding laminations. Quartzite interpreted as metachert (Shannon and McCalpin, 2006) and is commonly interlayered with amphibolite gneiss. East of the Arkansas River, most rocks mapped as metasedimentary rocks of the Gunnison-Salida volcano-plutonic belt are migmatitic biotite gneiss (Boardman, 1976; Van Alstine and Cox, 1969; Wallace and others, 1997; Wallace and Lawson, 1998). Van Alstine (1974) also reports some interbedded marble and calc-silicate gneiss (scarn)

Xmc Muscovite-cordierite schist-As mapped in the southern Maysville 7.5' quadrangle (Shannon and McCalpin, 2006), this distinctive rock unit is light-gray, fine- to mediumgrained, strongly foliated quartz-muscovite-cordierite-biotite-plagioclase-sillimanite schist with 1-2 percent magnetite and trace amounts of tourmaline. Dark-brown cordierite porphyroblasts are as long as about $2 \mathrm{~cm}$. Most samples are weakly magnetic due to the finely-disseminated magnetite. Muscovite-cordierite forms at least two laterally extensive northeast-trending layers that may be regionally mappable horizons (Shannon and McCalpin, 2006)

\section{METASEDIMENTARY AND METAIGNEOUS ROCKS}

YXm Intermixed metasedimentary and metaigneous rocks (Mesoproterozoic and Paleoproterozoic)—Mapped where individual units are either too small or not studied in detail. Primarily includes St. Kevin Granite (Ygs) intermixed with bodies of biotite gneiss (Xb), hornblende gneiss, and amphibolite (Xhg). Shown only in Homestake Reservoir $7.5^{\prime}$ quadrangle

$\mathrm{Xb}$ Biotite gneiss (Paleoproterozoic) - Mostly gray to dark-gray, fine- to medium-grained, moderately foliated to strongly foliated and layered gneiss and schist. Composed of quartz, plagioclase, microcline, and biotite; locally contains hornblende, sillimanite, and garnet. Accessory minerals are rutile, sphene, apatite, zircon, and magnetite. Sillimanite-bearing biotite schist (metapelite) crops out in and near the Twin Lakes mining district. Migmatitic in most places; contains numerous light-colored layers and lenses (leucosomes) typically $0.1-10 \mathrm{~cm}$ thick, although locally may be much thicker. In most places, leucosome bodies form less than half of rock, have sharp contacts with host rock, show much pinch and swell, and in some places are strongly folded. Leucosomes are composed of equigranular, massive to weakly foliated, white to light-gray microcline-plagioclase-quartz rock containing less than 5 percent biotite; accessory minerals are muscovite, opaque minerals, sphene, apatite, garnet, and zircon. Formation of leucosomes may be due to either injection or in situ partial melting (anatexis) (Johannes and Gupta, 1982; Olsen, 1982). In the case of partial melting, biotite gneiss adjacent to leucosomes commonly has biotite-rich selvages representing refractory material remaining after partial melting. Some areas mapped as biotite gneiss may include small bodies of granitic rock. Unit undated in map area, but similar rocks in the Gore Range and western Front Range, northeast of the map area, have a U-Pb zircon age of about 1,750-1,785 Ma (Kellogg and others, 2008, 2011), which represents the age of the source rocks from which detritus that comprises the sedimentary protolith was derived. In the same areas, $\mathrm{U}-\mathrm{Pb}$ zircon geochronology indicates that formation of migmatite (partial melting) occurred about 1,695 Ma, which is also the approximate time at which many pegmatites in and near these areas formed (Kellogg and others, 2011) 
Xhc

Hornblende gneiss, amphibolite, and calc-silicate gneiss (Paleoproterozoic)—Black to dark-gray, greenish black, greenish-white, and greenish-gray, interlayered hornblende gneiss, amphibolite, hornblende-pyroxene-plagioclase gneiss, quartzite, skarn, and minor biotite gneiss and schist. Layers generally ranges from $0.5-1 \mathrm{~m}$ thick with localized marble and quartzite layers up to $10 \mathrm{~m}$ thick

Xhg Hornblende gneiss and amphibolite (Paleoproterozoic)—Dark-gray to black, weakly to strongly foliated, layered, mostly medium grained, hornblende-plagioclase gneiss and amphibolite, locally containing variable but small amounts of biotite, quartz, and augite. Commonly has black-and-white mottled texture due to weathered plagioclase (white) and hornblende (black). Amphibolite contains $>50$ percent amphibole. Intimately interlayered in places with more felsic gneissic rocks, so many small, unmapped bodies of unit Xhg are included with other units, such as biotite gneiss $(\mathrm{Xb})$. Contains a quartzite layer (qz) at one locality in Maysville 7.5' quadrangle that is interpreted as a metachert (Shannon and McCalpin, 2006). Protolith interpreted as mafic volcanic rocks and minor intrusive rocks that were emplaced during several episodes

\section{Acknowledgments}

This report was much improved by reviews from Vince Mathews, former director of the Colorado Geological Survey, and by Margaret Berry and Joe Colgan, U.S. Geological Survey. Jeremy Havens, ADC Management Services, Inc., drafted some of the figures in this report.

\section{References Cited}

Adams, J.W., 1953, Beryllium deposits of the Mount Antero region, Chaffee County, Colorado: U.S. Geological Survey Bulletin 982-D, 119 p. [Also available at https://pubs. er.usgs.gov/publication/b982D.]

AeroMetric, Inc., 2010, lidar coverage: Norcross, Ga., Quantum Spatial, available at https://quantumspatial.com/.

Aleinikoff, J.N., Reed, J.C., Jr., and Wooden, J.L., 1993, Lead isotopic evidence for the origin of Paleo- and Mesoproterozoic rocks of the Colorado Province, U.S.A.: Precambrian Research, v. 63, p. 97-122.

Bade, C.T., 1989, Geologic study of the volcanic units in the Bald Mountain-Castle Rock region, Chaffee County, Colorado: Bowling Green, Ohio, Bowling Green State University, M.S. thesis, $105 \mathrm{p}$.

Barker, Fred, and Brock, M.R., 1965, Denny Creek Granodiorite Gneiss, Browns Pass Quartz Monzonite, and Kroenke Granodiorite, Mount Harvard quadrangle, Colorado, in Cohee, G.V., and West, W.S., eds., Changes in stratigraphic nomenclature by the U.S. Geological Survey, 1964: U.S. Geological Survey Bulletin 1224-A, p. A23-A26. [Also available at https://pubs.er.usgs.gov/publication/b1224A.]
Barker, Fred, Peterman, Z.E., Henderson, W.T, and Hildreth, R.A., 1974, Rubidium-strontium dating of the trondhjemite of Rio Brazos, New Mexico, and of the Kroenke Granodiorite, Colorado: U.S. Geological Survey Journal of Research, v. 2, p. 705-709. [Also available at http://pubs. usgs.gov/journal/1974/vol2issue6/report.pdf\#page=69.]

Barnosky, A.D., Bell, C.J., Emslie, S.D., Goodwin, H.T., Mead, J.I., Repenning, C.A., Scott, Eric, and Shabel, A.B., 2004, Exceptional record of mid-Pleistocene vertebrates help differentiate climatic from anthropogenic ecosystem perturbations: Proceedings of the National Academy of Science, v. 101, no. 25, p. 9297-9302.

Barsch, Dietrich, 1987, The problem of ice-cored rock glaciers, in Shroder, J.F., and Vitek, J.D., eds., Rock glaciers: London, Allen and Unwin, p. 45-53.

Beaty, D.W., Cunningham, C.G., Harrison, W.J., Landis, G.P., Merchant, J.S., Naeser, C.W., and Wendlandt, R.F., 1990, Origin of the ore deposits at Gillman, Colorado, in Beaty, D.W., Landis, G.P., and Thompson, T.B., eds., Carbonatehosted sulfide deposits in the central Colorado mineral belt: Economic Geology Monograph no. 7, p. 255-265.

Behre, C.H., Jr., 1932, The Weston Pass mining district, Lake and Park Counties, Colorado: Proceedings of the Colorado Scientific Society, v. 13, no. 3, p. 51-75.

Behre, C.H., Jr., 1953, Geology and ore deposits of the west slope of the Mosquito Range: U.S. Geological Survey Professional Paper 235, 175 p., scale 1:12,000. [Also available at https://pubs.er.usgs.gov/publication/pp235.]

Benedict, J.B., 1973a, Origin of rock glaciers: Journal of Glaciology, v. 12, p. 520-522. 
Benedict, J.B., 1973b, Chronology of cirque glaciation, Colorado Front Range: Quaternary Research, v. 3, p. 585-599.

Benedict, J.B., 1985, Arapaho Pass-Glacial geology and archeology at the crest of the Colorado Front Range: Ward, Colo., Center for Mountain Archeology, Research Report no. 3, $197 \mathrm{p}$.

Benson, L.V., Madole, R.F., Phillips, W.M., Landis, G.P., Thomas, Terry, and Kubic, P.W., 2004, The probable importance of snow and sediment shielding on cosmogenic ages of north-central Colorado Pinedale and pre-Pinedale moraines: Quaternary Science Reviews, v. 23, p. 193-206.

Benson, L.V., Madole, R.F., Landis, G.P., and Gosse, J.C., 2005, New data for late Pleistocene alpine glaciation from southwestern Colorado: Quaternary Science Reviews, v. 24, p. 46-65.

Berkman, F.E., and Watterson, N.A., 2010, Interpretive geothermal map of Colorado: Colorado Geological Survey. 3 pl. [CD-ROM]

Bickford, M.E., and Boardman, S.J., 1984, A Proterozoic volcano-plutonic terrane, Juggison and Salida areas, Colorado, Journal of Geology, v. 92, p. 657-666.

Bickford, M.E., and Hill, B.M., 2007, Does the arc accretion model adequately explain the Paleoproterozoic evolution of southern Laurentia? An expanded interpretation: Geology, v. 35 , p. $167-170$.

Bickford, M.E., Mueller, P.A., Kamenov, G.D., and Hill, B.M., 2008, Crustal evolution of southern Laurentia during the Paleoproterozoic - Insights from zircon $\mathrm{Hf}$ isotopic studies of ca. 1.75 Ga rocks in central Colorado: Geology, v. 36, p. 555-558.

Bickford, M.E., Schuster, R.D., and Boardman, S.J., 1989, $\mathrm{U}-\mathrm{Pb}$ geochronology of the Proterozoic volcano-plutonic terrane in the Gunnison and Salida areas, Colorado, in Grambling, J.A., and Tewksbury, B.J., eds., Proterozoic geology of the southern Rocky Mountains: Geological Society of America Special Paper 235, p. 33-48.

Bickford, M.E., Van Schmus, W.R., and Zietz, I., 1986, Proterozoic history of the mid-continent region of North America: Geology, v. 14, p. 492-496.

Birkeland, P.W., 1999, Soils and geomorphology: New York, Oxford University Press, $430 \mathrm{p}$.

Boardman, S.J., 1976, Geology of the Precambrian metamorphic rocks of the Salida area, Chaffee County, Colorado: The Mountain Geologist, v. 13, no. 3, p. 89-100.

Boardman, S.J., and Condie, K.C., 1986, Early Proterozoic bimodal volcanic rocks in central Colorado, U.S.A., Part II, Geochemistry, petrogenesis and tectonic setting: Precambrian Research, v.34, p. 37-68.
Bohannon, R.G., and Ruleman, C.A., 2013, Geologic map of the Mount Sherman 7.5' quadrangle, Lake and Park Counties, Colorado: U.S. Geological Survey Scientific Investigations Map 3271, scale 1:24,000. [Also available at https://pubs.er.usgs.gov/publication/sim3271.]

Bookstrom, A.A., 1989, The Climax-Alma granite batholith of Oligocene age and the porphyry molybdenum deposits of Climax, Colorado, U.S.A.: Engineering Geology, v. 27, p. 543-568.

Briner, J.P., 2009, Moraine pebbles and boulders yield indistinguishable ${ }^{10} \mathrm{Be}$ ages - A case study from Colorado, USA: Quaternary Geochronology, v. 4, p. 299-305.

Brock, M.R., and Barker, Fred, 1972, Geology of the Mount Harvard quadrangle: U.S. Geological Survey Geologic Quadrangle Map GQ-952, scale 1:62,500. [Also available at https://pubs.er.usgs.gov/publication/gq952.]

Brugger, K.A., 2007, Cosmogenic ${ }^{10} \mathrm{Be}$ and ${ }^{36} \mathrm{Cl}$ ages from late Pleistocene terminal moraine complexes in the Taylor river drainage basin, central Colorado, USA: Quaternary Science Reviews, v. 26, p. 494-499.

Brugger, K.A., Leonard, E. M., Lee, Keenan, and Bush, M.A., 2011, Discharge estimates for a glacial outburst paleoflood on the upper Arkansas River, Colorado, from an ice-dam failure model [abs.]: Geological Society of America Abstracts with Programs, v. 43, no. 4, p. 10.

Bryant, Bruce, 1971, Movement measurements on two rock glaciers in the eastern Elk Mountains, Colorado, chap. B of Geological Survey Research, 1971: U.S. Geological Survey Professional Paper 750-B, p. B108-B116. [Also available at https://pubs.er.usgs.gov/publication/gq952.]

Bryant, Bruce, Marvin, R.F., Naeser, C.W., and Mehnert, H.H., 1981, Ages of igneous rocks in the South ParkBreckenridge region, Colorado, and their relation to the tectonic history of the Front Range uplift, in Shorter contributions to isotope research in the western United States, 1980: U.S. Geological Survey Professional Paper 1199 A-E, p. 15-35.

Bryant, Bruce, and Naeser, C.W., 1980, Significance of fission-track ages of apatite in relation to the tectonic history of the Front and Sawatch Ranges, Colorado: Geological Society of America Bulletin, Part 1, v. 91, p. 156-164.

Cannon, S.H., Kirkham, R.M., and Parise, Mario, 2001, Wildfire-related debris-flow initiation processes, Storm King Mountain, Colorado: Geomorphology, v. 39, p. 171-188.

Cappa, J.A., and Bartos, P.J., 2007, Geology and mineral resources of Lake County, Colorado: Colorado Geological Survey Resource Series 42, 59 p. [CD-ROM]

Capps, S.R., Jr., 1909, Pleistocene geology of the Leadville quadrangle, Colorado: U.S. Geological Survey Bulletin 386, 99 p. [Also available at https://pubs.er.usgs.gov/publication/b386.] 
Case, J.E., and Sikora, R.F., 1984, Geologic interpretation of gravity and magnetic data in the Salida region, Colorado: U.S. Geological Survey Open-File Report 84-372, 46 p. [Also available at https://pubs.er.usgs.gov/publication/ ofr84372.]

Chadwick, O.A., Hall, R.D., and Phillips, F.M., 1997, Chronology of Pleistocene glacial advances in the central Rocky Mountains: Geological Society of America Bulletin, v. 109 , p. 1443-1452.

Chamberlain, K.R., 1998, Medicine Bow orogeny-Timing of deformation and model of crustal structure produced during continental-arc collision, ca., 1.78 Ga, southeastern Wyoming: Rocky Mountain Geology, v. 33, no. 2, p. 259-277.

Chapin, C.E., 1979, Evolution of the Rio Grande Rift-A summary, in Riecker, R.E., ed., Rio Grande rift-Tectonics and magmatism: Washington, D.C., American Geophysical Union, p. 1-5.

Chapin, C.E., and Cather, S.M., 1994, Tectonic setting of the axial basins of the northern and central Rio Grande rift, in Keller, G.R., and Cather, S.M., eds., Basins of the Rio Grande Rift - Structure, stratigraphy, and tectonic setting: Geological Society of America Special Paper 291, p. 5-25.

Chapin, C.E., and Epis, R.C., 1964, Some stratigraphic and structural features of the Thirtynine Mile volcanic field, central Colorado: the Mountain Geologist, v. 1, no. 3, p. 145-160.

Chronic, John, 1958, Pennsylvanian rocks in central Colorado, in Curtis, B.F., ed., Symposium on Pennsylvanian rocks of Colorado and adjacent areas: Rocky Mountain Association of Geologists, p. 59-63.

Chronic, John, 1964, Geology of the southern Mosquito Range, Colorado: The Mountain Geologist, v. 1, p. 103-113.

Clark, P.U., and Pollard, David, 1998, Origin of the middle Pleistocene transition by ice sheet erosion of regolith: Paleoceanography, v. 13, p. 1-9.

Cobban, W.A., 1993, Diversity and distribution of Cretaceous ammonites, western United States, in Caldwell, W.G.E., and Kauffman, E.G. eds., Evolution of the western interior basin: Geological Society of Canada Special Paper 39, p. 435-451.

Coe, J.A., Kean, J.W., McCoy, S.W., Staley, D.M., and Wasklewicz, T.A., 2010, Chalk Creek Valley-Colorado's natural debris-flow laboratory, in Morgan, L.A., and Quane, S.L., eds., Through the generations - Geologic and anthropogenic field excursions in the Rocky Mountains from modern to ancient, 2010 Denver annual meeting, Geological Society of America Field Guide 18, p. 95-117.
Coe, J.A., Ruleman, C.A., Godt, J.W., Matthews, Vincent, III, Goehring, B.M., Lucha, Pedro, Deuell, A.E., and Reeves, R.R., 2013, Long-term measurement of ridge-spreading movements (sackungen) at Bald Eagle Mountain, central Colorado [abs.]: Geological Society of America Abstracts with Programs, v. 45, no. 7, p. 643.

Colman, S.M., McCalpin, J.P., Ostenaa, D.A., and Kirkham, R.M., 1985, Map showing upper Cenozoic rocks and deposits and Quaternary faults, Rio Grande Rift, south-central Colorado: U.S. Geological Survey Miscellaneous Geologic Investigations I-1594, 2 sheets, scale 1:125,000. [Also available at https://pubs.er.usgs.gov/publication/i1594.]

Colorado Geological Survey, 2013, Colorado's largest earthquakes: Colorado Geological Survey, Geologic Hazards, accessed in 2013 at: http://coloradogeologicalsurvey.org/ geologic-hazards/earthquakes/colorados-largest-earthquakes/.

Coolbaugh, M.F., 1985, Geology and economic mineral potential of upper Browns Creek basin, Chaffee County, Colorado: Phoenix, University of Arizona, M.S. thesis, 243 p.

Cruden, D.M., and Varnes, D.J., 1996, Landslide types and processes, in Turner, A.K., and Schuster, R.L., eds., Landslides investigation and mitigation: National Academy Press, Washington, D.C., p. 36-75.

Cunningham, C.G., Naeser, C.W., Marvin, R.F., Luedke, R.G., and Wallace, A.R., 1994, Ages of selected intrusive rocks and associated ore deposits in the Colorado mineral belt: U.S. Geological Survey Bulletin 2109, 31 p. [Also available at https://pubs.er.usgs.gov/publication/b2109.]

Dalrymple, G.B., 1979, Critical tables for conversion of K-Ar ages from old to new constraints: Geology, v. 7, p. 558-560.

Davis, P.T., 1988, Holocene glacier fluctuations in the American Cordillera: Quaternary Science Reviews, v. 7, p. 129-157.

De Voto, R.H., 1971, Geologic history of South Park and geology of the Antero Reservoir quadrangle, Colorado: Colorado School of Mines Quarterly, v. 66, no. 4, 90 p., scale: 1:62,500.

De Voto, R.H., 1980, Pennsylvanian stratigraphy and history of Colorado, in Kent, H.C. and Porter, K.W., eds., Colorado geology: Rocky Mountain Association of Geologists, p. 71-101.

De Voto, R.H., and Peel, F.A., 1972, Pennsylvanian and Permian stratigraphy and structural history, northern Sangre de Cristo Range, Colorado: Golden, Colo., Colorado School of Mines Quarterly, v. 67, p. 283-320.

DeWitt, Ed, Premo, W.R., and Klein, Terry, 2010, The Early Proterozoic Poudre Basin, an important constraint on 1.77-1.73-Ga tectonic events in western Colorado [abs.]: Geological Society of America Abstracts with Programs, v. 42 , no. 5 , p. 654 . 
Dings, M.R., and Robinson, C.S., 1957, Geology and ore deposits of the Garfield quadrangle, Colorado: U.S. Geological Survey Professional Paper 289, 110 p. [Also available at https://pubs.er.usgs.gov/publication/pp289.]

Emmons, S.F., Hillebrand, W.F., and Guyard, Antony, 1886, Geology and mining industry of Leadville, Colorado: U.S. Geological Survey, Monograph 12, with atlas, 770 p. [Also available at https://pubs.er.usgs.gov/publication/m12.]

Emmons, S.F. 1898, Tenmile District: U.S. Geological Survey Geologic Atlas, Special Folio 48. [Also available at https:// pubs.er.usgs.gov/publication/gf48.]

Emmons, S.F., and Irving, J.D., 1907, The downtown district of Leadville, Colorado: U.S. Geological Survey Bulletin 320, 75 p. [Also available at https://pubs.er.usgs.gov/ publication/b320.]

Emmons, S.F., Irving, J.D., and Loughlin, G.F., 1927, Geology and ore deposits of the Leadville mining district, Colorado: U.S. Geological Survey Professional Paper 148, 368 p. [Also available at https://pubs.er.usgs.gov/publication/pp148.]

Epis, R.C., and Chapin, C.E., 1974, Stratigraphic nomenclature of the Thirtynine Mile volcanic field, central Colorado: U.S. Geological Survey Bulletin 1395-C, 23 p. [Also available at https://pubs.er.usgs.gov/publication/b1395C.]

Epis, R.C., and Chapin, C.E., 1975, Geomorphic and tectonic implications of the post-Laramide, late Eocene erosion surface in the southern Rocky Mountains, in Curtis, Bruce, ed., Cenozoic history of the southern Rocky Mountains: Geological society of America Memoir 144, p. 44-74.

Epis, R.C., Scott, G.R., Taylor, R.B., and Chapin, C.E., 1980, Summary of Cenozoic geomorphic, volcanic, and tectonic features of central Colorado and adjacent areas, in Kent, H.C., and Porter, K.W., eds., Colorado geology: Rocky Mountain Association of Geologists Symposium Proceedings, Denver, p. 135-156.

Evans, J.E., and Reed, J.M., 2007, Integrated loessitepaleokarst depositional system, Early Pennsylvanian Molas Formation, Paradox Basin, southwestern Colorado, U.S.A.: Sedimentary Geology, v. 195, p. 161-181.

Fridrich, C.J., DeWitt, Ed, Bryant, Bruce, Richard, Steve, and Smith, R.P., 1998, Geologic map of the Collegiate Peaks Wilderness area and the Grizzly Peak caldera, Sawatch Range, central Colorado; U.S. Geological Survey Miscellaneous Investigations Series I-2565, scale 1:50,000. [Also available at https://pubs.er.usgs.gov/publication/i2565.]

Gese, D.D., and Scott, D.C., 1993, Regional mineral appraisal of the Leadville 2 degree quadrangle: Bureau of Mines, Mineral Land Assessment Open-File Report 20-93, 324 p.

Gould, D.B, 1935, Stratigraphy and structure of Pennsylvanian rocks in Salt Creek area, Mosquito Range, Colorado:
American Association of Petroleum Geologists Bulletin, v. 19 , no. 7, p. 971-1009.

Graubard, C.M., and Mattison, J.M., 1990, Syntectonic emplacement of the $\sim 1440 \mathrm{Ma}$ Mt. Evans pluton and history of motion along the Idaho Springs-Ralston Creek shear zone, central Colorado [abs.]: Geological Society of America Abstracts with Programs, v. 22, no. 2, p. 12.

Guido, Z.S., Ward, D.J., and Anderson, R.S., 2007, Pacing the post-Last Glacial Maximum demise of the animas Valley glacier and the San Juan Mountains ice cap, Colorado: Geology, v. 35, no. 8, p. 739-742.

Hayden, F.V., 1874, [Seventh] Annual Report of the United States Geological and Geographical Survey of the Territories, embracing Colorado-Being a report of progress of the exploration for the year 1873: Washington, D.C., Government Printing Office, 718 p.

Hedlund, D.C., 1985, Geologic map of the Buffalo Peaks Wilderness Study Area, Lake, Park, and Chaffee Counties, Colorado: U.S. Geological Survey Miscellaneous Field Studies Map MF-1628-C, scale 1:50,000. [Also available at https://pubs.er.usgs.gov/publication/mf1628C.]

Hedlund, D.C., Nowlan, G.S., and Wood, R.H., II, 1983, Mineral resource potential map of the Buffalo Peaks Wilderness Study Area, Lake, Park, and Chaffee Counties, Colorado: U.S. Geological Survey, Miscellaneous Field Studies Map MF-1628-A, 18 p., 1 sheet, scale 1:50,000. [Also available at https://pubs.er.usgs.gov/publication/ mf1628A.]

Henderson, C.W., 1926, Mining in Colorado, a history of discovery, development and production: U.S. Geological Survey, Professional Paper 138, 263 p. [Also available at https://pubs.er.usgs.gov/publication/pp138.]

Hill, B.M., and Bickford, M.E., 2001, Paleoproterozoic rocks of central Colorado- Accreted arcs or extended older crust?: Geology, v. 29, no. 11, p. 1015-1018.

Houck, K. J., Fleming, James, Guerrero, Raquel, Heimink, Nicole, Heberton, Alyssa, Itano, Wayne, Titus, Alan, and Barrick, J.E., 2004, Paleontology of the Bassam Park fossil beds (Pennsylvanian), San Isabel National Forest, Colorado [abs.], in 2004 Denver annual meeting, Nov. 7-10, 2004: Denver, Colo., Geological Society of America Abstracts with Programs, v. 36, no. 5, p. 413.

Houck, K.J., Funk, J.A., Kirkham, R.M., Carroll, C.J., and Heberton-Morimoto, A.D., 2012, Marmot Peak quadrangle geologic map, Park and Chaffee Counties, Colorado: Colorado Geological Survey Open-File Map 12-1, scale 1:24,000.

Howell, J.V., 1919, Twin Lakes district of Colorado: Colorado Geological Survey, Bulletin 17, 108 p. 
Hubbard, M.S., Oviatt, C.G., Kelley, S., Perkins, M.E., Hodges, K.V., and Robbins, R., 2001, Oligocene-Miocene basin formation and modification in the northern Rio Grande rift; constraints from ${ }^{40} \mathrm{Ar} /{ }^{39} \mathrm{Ar}$, fission track and tephrochronology [abs.], in Geological Society of America Annual Meeting, Nov. 5-8, 2001, session no. 108., Boston, Mass.: Geological Society of America Abstracts with Programs, v. 33, no. 6, p. A-257.

Hudson, M.R., and Grauch, V.J.S., 2013, Introduction, in Hudson, M.R., and Grauch, V.J.S., eds., New Perspective on Rio Grande Rift basins-From tectonics to groundwater: Geological Society of America Special Paper 494, p. 1-20, http://specialpapers.gsapubs.org/content/494.

Izett, G.A., 1968, Geology of the Hot Sulphur Springs quadrangle, Grand County, Colorado: U.S. Geological Survey Professional Paper 586, 79 p., scale 1:62,500. [Also available at https://pubs.er.usgs.gov/publication/pp586.]

Izett, G.A., and Wilcox, R.E., 1982, Map showing localities and inferred distributions of the Huckleberry Ridge, Mesa Falls, and Lava Creek ash beds (Pearlette family ash beds) of Pliocene and Pleistocene age in the western United States and Canada: U.S. Geological Survey Miscellaneous Investigations Series Map I-1325, scale 1:4,000,000. [Also available at https://pubs.er.usgs.gov/publication/i1325.]

Izett, G.A., Wilcox, R.E., Powers, H.A., and Desborough, G.A., 1970, The Bishop ash bed, a Pleistocene marker bed in the Western United States: Quaternary Research, v. 1, p. 121-132.

Izett, G.A., Obradovich, J.D., and Mehnert, H.H., 1988, The Bishop ash bed (middle Pleistocene) and some older (Pliocene and Pleistocene) chemically and mineralogically similar ash beds in California, Nevada, and Utah: U.S. Geological Survey Bulletin 1675, 37 p. [Also available at https://pubs.er.usgs.gov/publication/b1675.]

Jacobson, M.I., 1979, Famous mineral localities-Mount Antero: The Mineralogical Report, v. 10, no. 6, p. 339-346.

Janke, J.R., 2007, Colorado Front Range rock glaciersDistribution and topographic characteristics: Arctic, Antarctic, and Alpine Research, v. 39, p. 74-83.

Johannes, W., and Gupta, L.N., 1982, Origin and evolution of a migmatite: Contributions to Mineralogy and Petrology, v. 79 , p. $114-123$.

Keller, J.W., McCalpin, J.P., and Lowry, B.W., 2004, Geologic map of the Buena Vista East quadrangle, Chaffee County, Colorado: Colorado Geological Survey Open-File Report 04-4, scale 1:24,000.

Kellogg, K.S., 1999, Neogene basins of the northern Rio Grande rift; partitioning and asymmetry inherited from Laramide and older uplifts: Tectonophysics, v. 305, p. 141-152.
Kellogg, K.S., 2001, Tectonic controls on a large landslide complex-Williams Fork Mountains near Dillon, Colorado: Geomorphology, v. 41, p. 355-368.

Kellogg, K.S., Bryant, Bruce, and Shroba, R.R., 2016, Mountains, glaciers, and mines-The geological story of the Blue River valley, Colorado, and its surrounding mountains: U.S. Geological Survey Circular 1400, 46 p., http://dx.doi.org/10.3133/cir1400.

Kellogg, K.S., Lee, Keenan, Premo, W.R., and Cosca, M.A, 2013, Geologic map of the Harvard Lakes 7.5' quadrangle, Chaffee County, Colorado: U.S. Geological Survey Scientific Investigations Map 3267, 22 p., scale 1:24,000, http://dx.doi.org/10.3133/sim3267.

Kellogg, K.S., Schmidt, C.J., and Young, S.W., 1995, Basement and cover-rock deformation during Laramide contraction in the northern Madison Range (Montana) and its influence on Cenozoic basin formation: American Association of Petroleum Geologists Bulletin, v. 79, no. 8, p. 1117-1137.

Kellogg, K.S., Shroba, R.R., Bryant, Bruce, and Premo, W.R., 2008, Geologic map of the Denver West 30' $\times 60^{\prime}$ quadrangle, Colorado: U.S. Geological Survey Scientific Investigations Map 3000, scale 1:100,000. [Also available at https://pubs.er.usgs.gov/publication/sim3000.]

Kellogg, K.S., Shroba, R.R., Premo, W.R., and Bryant, Bruce, 2011, Geologic map of the eastern half of the Vail $30^{\prime} \times 60^{\prime}$ quadrangle, Eagle, Summit, and Grand Counties, Colorado: U.S. Geological Survey Scientific Investigations Map 3170, scale 1:100,000, 49 p., 1 sheet. [Also available at https:// pubs.usgs.gov/sim/3170/.]

Kellogg, K.S, Shroba, R.R., Ruleman, C.A., Bohannon, R.G., McIntosh, W.C., Premo, W.R., Cosca, M.A., Moscati, R.J., Brandt, T.R., and Van Sistine, D. Paco., 2017, Data release for geologic map of the upper Arkansas River valley region, north-central Colorado: U.S. Geological Survey data release, https://doi.org/10.5066/F75B00XQ.

Kirkham, R.M., Houck, K.J., Carroll, C.J., and HebertonMorimoto, A.D., 2012, Antero Reservoir quadrangle geologic map, Park and Chaffee Counties, Colorado Geological survey Open-File Map 12-1, scale 1:24,000.

Kirkham, R.M., Houck, K.J., and Lindsay, N.R., 2007, Geologic map of the Garo quadrangle, Park County, Colorado: Colorado Geological Survey Open-file Report 07-6, scale 1:24,000.

Kirkham, R.M., and Rogers, W.P., 1981, Earthquake potential in Colorado: Colorado Geological Survey Bulletin 43, 171 p.

Knepper, D.H., 1974, Tectonic analysis of the Rio Grande rift zone, central Colorado: Golden, Colo., Colorado School of Mines Ph.D. dissertation (T-1593), 237 p. 
Kuiper, K.F., Deino, Alan, Hilgen, F.J., Krijgman, W., Rene, P.R., and Wijbrams, J.R., 2008, Synchronizing rock clocks of Earth history: Science, v. 320, p. 500-504.

Lanphere, M.A., 2000, Duration of sedimentation of the Creede Formation from ${ }^{40} \mathrm{Ar} /{ }^{39} \mathrm{Ar}$ ages, in Bethke, P.M., and Hay, H.L., eds., Ancient Lake Creede-Its volcanotectonic setting, history of sedimentation, and relation to mineralization in the Creede mining district: Geological society of America Special Paper 346, p. 71-76.

Lanphere, M.A., Champion, D.E., Christiansen, R.L., Izett, G.A., and Obradovich, J.D., 2002, Revised ages for tuffs of the Yellowstone Plateau volcanic field-Assignment of the Huckleberry Ridge Tuff to a new geomagnetic polarity event: Geological Society of America, v. 114, p. 559-568.

Le Bas, M.J., and Streckeisen, A.L., 1991, The IUGS systematics of igneous rocks: Journal of the Geological Society of London, v. 148, p. 825-833.

Lee, Keenan, 2010, Catastrophic glacial outburst floods on the Arkansas River, Colorado: The Mountain Geologist, v. 47, no. 2, p. 35-57.

Leonard, E.M., Hubbard, M.S., Kelly, S.A., Evanoff, Emmett, Siddoway, C.S., Oviatt, C.G., Heizler, Matt, and Timmons, Mike, 2002, High Plains to Rio Grande rift-Late Cenozoic evolution of central Colorado in Lageson, D., ed., Science at the highest level, Denver 2002, annual meeting: Geological Society of America Field Guide 3, p. 59-93.

Licciardi, J.M., and Pierce, K.L., 2008, Cosmogenic exposureage chronologies of Pinedale and Bull Lake glaciations in greater Yellowstone and the Teton Range, USA: Quaternary Science Reviews, p. 814-831.

Limbach, F. W., 1975, The geology of the Buena Vista area, Chaffee County, Colorado: Golden, Colo., Colorado School of Mines, M.S. thesis, 98 p.

Lipman, P.W., 2000, Central San Juan caldera cluster-Regional volcanic framework, in Bethke, P.M., and Hay, R.L., eds., Ancient Lake Creede-Its volcano-tectonic setting, history of sedimentation, and relation to mineralization in the Creede mining district: Geological Society of America Special Paper 346, p. 9-69.

Lipman, P.W., and Mehnert, H.W., 1975, Late Cenozoic basaltic volcanism and development of the Rio Grande depression in the southern Rocky Mountains, in Curtis, B.F., ed., Cenozoic history of the southern Rocky Mountains: Geological Society of America Memoir 144, p. 119-154.

Lipman, P.W., Zimmerer, M.J., and McIntosh, W.C., 2015, An ignimbrite caldera from the bottom up - Exhumed floor and fill of the resurgent Bonanza caldera, Southern Rocky Mountain volcanic field: Geosphere, v. 11, no. 6, p. 1902-1947.

Lisiecki, L.E., and Raymo, M.E., 2005, A Pliocene-Pleistocene stack of 57 globally distributed benthic $\delta^{18} \mathrm{O}$ records:

Paleoceanography, v. 20, PA1003, 17 p.
Lowell, G.R., 1971, Cenozoic geology of the Arkansas Hills region of the southern Mosquito Range, central Colorado: New Mexico Geological Society Guidebook, 22nd Field Conference, p. 209-217.

Mach, C.J., 1992, Geology and mineral deposits of the Kokomo District: Fort Collins, Colo., Colorado State University, M.S. thesis, 154 p.

Madole, R.F., 1986, Lake Devlin and Pinedale glacial history, Front Range, Colorado: Quaternary Research, v. 25, p. 43-54.

Madole, R.F., 2010, Evidence from the Front Range, Colorado, indicates that Pinedale glaciation began before 31,000 yr ago [abs.], in Geological Society of America Annual Meeting, Denver, Colo., Oct. 31-Nov. 3, 2010: Denver, Colo., Geological Society of America Abstracts with Programs, v. 42, no. 5, p. 363.

Madole, R.F, VanSistine, D. Paco, and Romig, J.H., 2016, Geologic map of Great Sand Dunes National Park, Colorado: U.S. Geological Survey Scientific Investigations Map 3362, 58 p., scale 1:35,000, http://dx.doi.org/10.3133/sim3362.

Marvin, R.F., Mehnert, H.H., Naeser, C.W., and Zartman, R.E., 1989, U.S. Geological Survey radiometric ages compilation C-Part five; Colorado, Montana, Utah, and Wyoming: Isochron/West, no. 53, p. 14-19.

Mason, Cody, and Ruleman, C.A., 2011, Rate and timing of deglaciation using ${ }^{10} \mathrm{Be}$ cosmogenic nuclide surface exposure dating, Mt. Massive Wilderness, Colorado, USA [abs.] in, Geological Society of America Annual Meeting and Exposition, Oct. 9-12, 2011, Minneapolis, Minn.: Geological Society of America Abstracts with Programs v. 43 , no. 5 , p. 65 .

McCalpin, J.P., Funk, Jonathan, and Mendel, David, 2012, Leadville South quadrangle geologic map, Lake County, Colorado: Colorado Geological Survey Open-File Report 09-5, scale 1:24,000.

McCalpin, J.P., Temple, Jay, Sicard, Karri, Mendel, David, and Ahmad, Bashir, 2012, Geologic map of the Climax quadrangle, Lake and Park Counties, Colorado: Colorado Geological Survey Open-File Report 08-17, scale 1:24,000.

McCalpin, J.P., and Shannon, J.R., 2005, Geologic map of the Buena Vista West quadrangle, Chaffee County, Colorado: Colorado Geological Survey Open-File Report 05-8, scale 1:24,000.

McDowell, F.W., 1971, K-Ar ages of igneous rocks from the western United States: Isochron/West, no. 2, p. 1-4.

McIntosh, W.C., and Chapin, C.E., 2004, Geochronology of the central Colorado volcanic field, in Cather, S.M., McIntosh, W.C., and Kelley, S.A., eds., Tectonics, geochronology, and volcanism in the southern Rocky Mountains and Rio Grande rift: New Mexico Bureau of Geology and Mineral Resources Bulletin 160, p. 205-237. 
McMillan, M.E., Heller, P.L., and Wing, S.L., 2006, History and causes of post-Laramide relief in the Rocky Mountain orogenic plateau: Geological Society of America Bulletin, v. 118 , no. $3 / 4$, p. $393-405$.

Mears, Brainard, Jr., 1998, Neogene faulting superposed on a Laramide uplift-Medicine Bow Mountains, Sierra Madre, and intervening Saratoga Valley, Wyoming and Colorado: Laramie, University of Wyoming, Contributions to Geology, v. 32 , p. $181-185$.

Miggins, D.P., 2002, Chronologic, geochemical, and isotopic framework of igneous rocks within the Raton Basin and adjacent Rio Grande rift, south-central Colorado and northern New Mexico: Boulder, Colo., University of Colorado, Ph.D. dissertation, $417 \mathrm{p}$.

Miller, C.D., 1973, Chronology of Neoglacial deposits in the northern Sawatch Range, Colorado: Arctic and Alpine Research, v. 5, p. 385-400.

Mills, R.D., and Coleman, D.S., 2013, Temporal and chemical connections between plutons and ignimbrites from the Mount Princeton magmatic center: Contributions to Mineralogy and Petrology, v. 165, p. 961-980.

Morgan, L.E., and Cosca, M.A., 2017, Argon data for Poncha Pass map: U.S. Geological Survey data release, https:// dx.doi.org/10.5066/F7PV6J8X.

Moscati, R.J., Premo, W.R., DeWitt, E.H., and Wooden, J.L., 2017, U-Pb ages and geochemistry of zircon from Proterozoic plutons of the Sawatch and Mosquito ranges, Colorado, U.S.A.- Implications for crustal growth of the central Colorado Province: Rocky Mountain Geology, v. 52, no. 1 , p. $17-106$.

Moscati, R.J., Premo, W.R., and DeWitt, E.H., 2012, SHRIMP-RG U-Pb geochronology and trace element geochemistry of zircons from Proterozoic granitic plutons in the Sawatch Range, Colorado, USA [abs.], in Geological Society of America Annual Meeting, Nov. 5, Charlotte, N.C.: Geological Society of America Abstracts with Programs, v. 44, no. 7, p. 234.

Myrow, P.M., Taylor, J.F., Miller, J.F., Ethington, R.L., Ripperton, R.L., and Allen, J., 2003, Fallen archesDispelling myths concerning Cambrian and Ordovician paleogeography of the Rocky Mountain region: Geological Society of America, v. 115, no. 6, p. 695-713.

Nelson, A.R., Millington, A.C., Andrews, J.T., and Nichols, H., 1979, Radiocarbon-dated upper Pleistocene glacial sequence, Fraser Valley, Colorado Front Range: Geology, v. 7 , p. $410-414$.

Nelson, A.R., and Shroba, R.R., 1984, Moraine and outwashterrace sequences and soil development in the north graben of the upper Arkansas Valley, central Colorado, part 2, of Nelson, A.R., Shroba, R.R., and Scott, G.R., eds., Quaternary stratigraphy of the upper Arkansas Valley, Guidebook for field trip 7: Boulder, Colo., American Quaternary Association 8th Biennial Meeting, p. 25-50.

Nelson, A.R., and Shroba, R.R., 1998, Soil relative dating of moraine and outwash-terrace sequences in the northern part of the upper Arkansas Valley, central Colorado, U.S.A.: Arctic and Alpine Research, v. 30, no. 4, p. 349-361.

Obradovich, J.D., 1993, A Cretaceous time scale, in Caldwell, W.G.E., and Kauffman, E.G., eds., Evolution of the western interior basin: Geological Association of Canada Special Paper 39, p. 379-396.

Obradovich, J.D., Mutschler, F.E., and Bryant, Bruce, 1969, Potassium-argon ages bearing on the igneous and tectonic history of the Elk Mountains and vicinity, Colorado-A preliminary report: Geological Society of America Bulletin, v. 77 , p. 1749-1756.

Olsen, S.N., 1982, Open- and closed-system migmatites in the Front Range, Colorado: American Journal of Science, v. 282 , p. $1596-1622$.

Ostenaa, D.A., Losh, S.L., and Nelson, A.R., 1980, Recurrent late Quaternary faulting in the upper Arkansas Valley near Buena Vista, Colorado [abs.]: Geological Society of America Abstracts with Programs, v. 12, no. 6, p. 300.

Ostenaa, D.A., Losh, S.L., and Nelson, A.R., 1981, Evidence for recurrent late Quaternary faulting, Sawatch fault, upper Arkansas Valley, Colorado, in Junge, W.R., ed., Colorado tectonics, seismicity and earthquake hazards - Proceedings and field trip guide: Colorado Geological Survey Special Publication 19, p. 27-29.

Outcalt, S. I., and Benedict, J.B., 1965, Photo-interpretation of two types of rock glaciers in the Colorado Front Range: Journal of Glaciology, v. 5, p. 849-856.

Parker, B.H., Jr., 1974a, Gold placers of Colorado (book 1): Colorado School of Mines Quarterly, v. 69, no. 3, 268 p.

Parker, B.H., Jr., 1974b, Gold placers of Colorado (book 2): Colorado School of Mines Quarterly, v. 69, no. 4, 224 p.

Pearson, R.C., Tweto, Ogden, Stern, T.W., and Thomas, H.H., 1962, Age of Laramide porphyries near Leadville, Colorado, in Short papers in geology and hydrology, articles 60-119: U.S. Geological Survey Professional Paper 450-C, p. 78-80. [Also available at https://pubs.er.usgs.gov/ publication/pp450C.]

Petersen, M. D., Frankel, A.D., Harmsen, S.C., Mueller, C.S., Haller, K.M., Wheeler, R.L., Wesson, R.L., Zeng, Yuehua, Boyd, O.S., Perkins, D.M., Luco, Nicolas, Field, E.H., Wills, C.J., and Rukstales, K.S., 2008, Documentation for the 2008 Update of the United States National Seismic Hazard Maps: U.S. Geological Survey Open-File Report 2008-1128, 61 p. 
Petersen, M.D., Moschetti, M.P., Powers, P.M., Mueller, C.S., Haller, K.M., Frankel, A.D., Zeng, Yuehua, Rezaeian, Sanaz, Harmsen, S.C., Boyd, O.S., Field, Ned, Chen, Rui, Rukstales, K.S., Luco, N, Wheeler, R.L., Williams, R.A., and Olsen, A.H., 2014, Documentation for the 2014 update of the United States national seismic hazard maps: U.S. Geological Survey Open-File Report 2014-1091, 243 p., http://dx.doi.org/10.333/ofr20141091.

Pierce, K.L., 2004, Pleistocene glaciation of the Rocky Mountains, in Gillespie, A.R., Porter, S.C., and Atwater, B.F., eds., The Quaternary Period in the United States: Amsterdam, Elsevier, p. 63-76.

Premo, W.R., Kellogg, K.S., Bryant, Bruce, 2007, SHRIMP $\mathrm{U}-\mathrm{Pb}$ zircon ages for Paleoproterozoic basement rocks from the northern and central Colorado Front Range-A refinement of the timing of crustal growth in the Colorado Province [abs.], in Geological Society of America Annual Meeting, Oct. 28-31, 2007, Denver, Colo.: Geological Society of America Abstracts with Programs, v. 39, no. 6, p. 221.

Pulfrey, R.J., 1971, Geology and geochemistry of the Mt. Antero granite and contiguous units, Chaffee County, Colorado: Oklahoma State University, M.S. thesis, 84 p.

Reed, J.C., Jr., Bickford, M.E., and Tweto, Ogden, 1993, Proterozoic accretionary terranes of Colorado and southern Wyoming, in Van Schmus, W.R., and Bickford, M.E., eds., volume $\mathrm{C}-2$, Transcontinental Proterozoic provinces, of Reed, J.C., Jr., Bickford, M.E., Houston, R.S., Link, P.K., Rankin, D.W., Sims, P.K., and Van Schmus, W.R., eds., Precambrian-Conterminous U.S., the geology of North America: Geological Society of America p. 211-228.

Richmond, G.M., and Fullerton, D.S., 1986, Introduction to Quaternary glaciations in the United States of America, in Richmond, G.M., and Fullerton, D.S., eds., Quaternary glaciations in the United States of America: Quaternary Science Reviews, v. 5, p. 3-10.

Ruleman, C.A., Bohannon, R.G., Bryant, Bruce, Shroba, R.R., and Premo, W.R., 2011, Geologic map of the Bailey 30' $\times 60^{\prime}$ quadrangle, north-central Colorado: U.S. Geological Survey Scientific Investigations Map 3156, scale 1:100,000. [Also available at https://pubs.usgs.gov/sim/3156/.]

Ruleman, C.A., Geohring, B.M., Mason, C., and Lundstrom, S.C., 2013, Late Pleistocene glacial maximum of the northern Sawatch Range, Mount Massive, Colorado [abs.]: Geological Society of America Abstracts with Programs, v. 45 , no. 7 , p. 551. [Also available at https://gsa.confex. com/gsa/2013AM/finalprogram/abstract_231017.htm.]

Sarna-Wojcicki, A.M., Pringle, M.S., and Wijbrans, Jan, 2000 , New ${ }^{40} \mathrm{Ar} /{ }^{39} \mathrm{Ar}$ age of the Bishop Tuff from multiple sites and sedimentation rate calibration of the MatuyamaBrunhes boundary: Journal of Geophysical Research, v. 105 , p. 21,43-21,443.
Schildgen, Taylor, Dethier, D.P., Bierman, Paul, and Caffee, Marc, 2002, ${ }^{26} \mathrm{Al}$ and ${ }^{10} \mathrm{Be}$ dating of late Pleistocene and Holocene fill terraces-A record of fluvial deposition and incision, Colorado Front Range: Earth Surface Process and Landforms, v. 27, p. 773-787.

Schweinsberg, A.D., Briner, J.P., Shroba, R.R., Licciardi, J.M., Leonard, E.M., Brugger, K.A., and Russell, C.M., 2016, Pinedale glacial history of the upper Arkansas River valley - New moraine chronologies, modeling results, and geologic mapping, in Keller, S.M., and Morgan, M.L., eds., Unfolding the geology of the west, Annual Meeting Geological Society of America, Denver, Colo.: September 25-28, 2016, Geological Society of America field guide 44, p. 335-353, doi:10.1130/2016.0044.

Scott, G.R., 1975, Reconnaissance geologic map of the Buena Vista quadrangle, Chaffee and Park Counties, Colorado: U.S. Geological Survey Miscellaneous Field Studies Map MF-657, scale 1:62,500. [Also available at https://pubs. er.usgs.gov/publication/mf657.]

Scott, G.R., 2004, Historic trail map of the Leadville $1^{\circ} \times 2^{\circ}$ quadrangle, central Colorado: U.S. Geological Survey Scientific Investigations Map 2820, 90 p., scale 1:250,000. [Also available at https://pubs.usgs.gov/sim/2004/2820/.]

Scott, G.R., and Cobban, W.A., 1965, Geologic and biostratigraphic map of the Pierre Shale between Jarre Creek and Loveland, Colorado: U.S. Geological Survey Miscellaneous Investigations Map I-439, 4 p., scale 1:48,000. [Also available at https://pubs.er.usgs.gov/publication/i439.]

Scott, G.R., Van Alstine, R.E., and Sharp, W.N., 1975, Geologic map of the Poncha Springs quadrangle, Chaffee County, Colorado: U.S. Geological Survey Miscellaneous Field Studies Map MF-658, scale 1:62,500. [Also available at https://pubs.er.usgs.gov/publication/mf658.]

Shannon, J.R., 1988, Geology of the Mount Aetna cauldron complex, Sawatch Range, Colorado: Golden, Colo., Colorado School of Mines, Ph.D. dissertation (T-3521), $434 \mathrm{p}$.

Shannon, J.R., Epis, R.C., Naeser, C.W., and Obradovich, J.D., 1987, Correlation of intracaldron and outflow tuffs and an intrusive tuff dike related to the Oligocene Mount Aetna cauldron, central Colorado: Golden, Colo., Colorado School of Mines Quarterly, v. 82, no. 4, p. 65-80.

Shannon, J.R. and McCalpin, J.P., 2006, Geologic map of the Maysville quadrangle, Chaffee County, Colorado: Colorado Geological Survey Open-File Report 06-10, 219 p, scale $1: 24,000$.

Sharp, W.N., 1976, Geologic map and details of the beryllium and molybdenum occurrences, Mount Antero, Chaffee County, Colorado: U.S. Geological Survey Map MF-810, scale 1:24,000. [Also available at https://pubs.er.usgs.gov/ publication $/ \mathrm{mf} 810 /$. 
Sharp, W.D., Ludwig, K.R., Chadwick, O.A., Amundson, Ronald, and Glaser, L.L., 2003, Dating fluvial terraces by ${ }^{230} \mathrm{Th} / \mathrm{U}$ on pedogenic carbonate, Wind River basin, Wyoming: Quaternary Research, v. 59, p. 139-150.

Shroba, R.R., 1977, Soil development in Quaternary tills, rock-glacier deposits, and taluses, southern and central Rocky Mountains: Boulder, University of Colorado, Ph.D. dissertation, $424 \mathrm{p}$.

Shroba, R.R., Rosholt, J.N., and Madole, R.F., 1983, Uraniumtrend dating and soil $\mathrm{B}$ horizon properties of till of Bull Lake age, North St. Vrain drainage basin, Front Range, Colorado: Geological Society of America Abstracts with Programs, v. 15 , no. 5, p. 431.

Shroba, R.R., Kellogg, K.S., and Brandt, T.R., 2014, Geologic map of the Granite 7.5' quadrangle, Lake and Chaffee Counties, Colorado: U.S. Geological Survey Scientific Investigations Map 3294, 31 p., 1 sheet, scale 1:24,000, http://dx.doi.org/10.3133/sim3294.

Singewald, Q.D., 1955, Sugar Loaf and St. Kevin mining districts, Lake County, Colorado: U.S. Geological survey Bulletin 1027-E, p. 251-259. [Also available at https:// pubs.er.usgs.gov/publication/b1027E.]

Singewald, Q.D., and Butler, B.S., 1941, Ore deposits in the vicinity of the London fault of Colorado: U.S. Geological Survey Bulletin 911, 74 p. [Also available at https://pubs. er.usgs.gov/publication/b911.]

Soil Survey Staff, 1999, Soil taxonomy - A basic system of soil classification for making and interpreting soil surveys ( $2 \mathrm{~d}$ ed.): U.S. Department of Agriculture Handbook 436, 869 p.

Steven, T.A., 2002, Late Cenozoic tectonic and geomorphic framework surrounding the evaporate dissolution area in west-central Colorado, in Kirkham, R.M., Scott, R.B., and Judkins, T.W., eds., Late Cenozoic evaporite tectonism and volcanism in west-central Colorado: Geological Society of America Special Paper 366, p. 15-30.

Thompson, T.B., and Arehart, G.B., 1990, Geology and origin of the ore deposits in the Leadville district, Colorado, Part 1, Geologic studies of ore bodies and wall rocks, in Beaty, D.W., Landis, G.P., and Thompson, T.B., eds., Carbonatehosted sulfide deposits of the central Colorado mineral belt: Economic Geology Monograph 7, p. 156-179.

Thompson, R.A., Johnson, C.M., and Mehnert, H.H., 1991, Oligocene basaltic volcanism of the northern Rio Grande Rift, San Luis Hills, Colorado: Journal of Geophysical Research, v., 96, no. B8, p. 13557-13592.

Toulmin, P., III, and Hammarstrom, J.M., 1990, Geology of the Mount Aetna volcanic center, Chaffee and Gunnison Counties, Colorado: U.S. Geological Survey Bulletin 1864, 44 p., scale 1:24,000. [Also available at https://pubs.er.usgs. gov/publication/b1864.]
Tweto, Ogden, 1951, Form and structure of sills near Pando, Colorado: Geological Society of America Bulletin, v. 62, p. 507-532.

Tweto, Ogden, 1961, Late Cenozoic events of the Leadville district and upper Arkansas Valley, Colorado, in Short papers in the geologic and hydrologic sciences, articles 1-146: U.S. Geological Survey Professional Paper 424-B, p. B133-B135. [Also available at https://pubs.er.usgs.gov/ publication/pp424B.]

Tweto, Ogden, 1968, Leadville district, Colorado, in Ridge, J.D., ed., Ore deposits of the United States, 1933-1967, Graton-Sales volume: New York, American Institute of Mining, Metallurgical, and Petroleum Engineers, p. 681-705.

Tweto, Ogden, 1974a, Geologic map of the Holy Cross 15-minute quadrangle, Eagle, Lake, Pitkin, and Summit Counties, Colorado: U.S. Geological Survey Miscellaneous Geological Investigations Map I-830, scale, 1:62,500.

Tweto, Ogden, 1974b, Geologic map of the Mount Lincoln 15-minute quadrangle, Eagle, Park, Lake, and Summit Counties, Colorado: U.S. Geological Survey Miscellaneous Field Studies Map MF-556, scale 1:62,500. [Also available at https://pubs.er.usgs.gov/publication/mf556.]

Tweto, Ogden, 1975, Laramide (Late Cretaceous-Early Tertiary) orogeny in the southern Rocky Mountains, in Curtis, B.F., ed., Cenozoic history of the Southern Rocky Mountains: Geological Society of America Memoir 144, p. 1-44.

Tweto, Ogden, 1979a, The Rio Grande rift system in Colorado, in Riecker, R.E., ed., Rio Grande rift-Tectonics and magmatism: Washington, D.C., American Geophysical Union, p. 33-56.

Tweto, Ogden, compiler, 1979b, Geologic map of Colorado: U.S. Geological Survey, scale 1:500,000. [Also available at http://ngmdb.usgs.gov/Prodesc/proddesc_68589.htm.]

Tweto, Ogden, 1987, Rock units of the Precambrian basement in Colorado: U.S. Geological Survey Professional Paper 1321-A, 54 p. [Also available at https://pubs.er.usgs.gov/ publication/pp1321A.]

Tweto, Ogden and Case, J.E., 1972, Gravity and magnetic features as related to geology in the Leadville 30-minute quadrangle, Colorado: U.S. Geological Survey Professional Paper 726-C, p. C1-C31. [Also available at https://pubs. er.usgs.gov/publication/pp726C.]

Tweto, Odgen, and Lovering, T.S., 1977, Geology of the Minturn 15-minute quadrangle, Eagle and Summit Counties, Colorado: U.S. Geological Survey Professional Paper 956, 96 p. [Also available at https://pubs.er.usgs.gov/ publication/pp956.] 
Tweto, Ogden, Moench, R.H., and Reed, J.C., 1978, Geologic map of the Leadville 1 degree by 2 degrees quadrangle, northwestern Colorado: U.S. Geological Survey Miscellaneous Geologic Investigations I-999, scale 1:250,000. [Also available at https://pubs.er.usgs. gov/publication/i999.]

Tweto, Ogden, and Reed, J.C., Jr., 1973, Reconnaissance geologic map of the Mount Elbert 15-minute quadrangle, Lake, Chaffee, and Pitkin Counties, Colorado: U.S. Geological Survey Open-File Report 1777, scale 1:62,500. [Also available at https://pubs.er.usgs.gov/publication/ ofr73287.]

Tweto, Ogden, and Sims, P.F., 1963, Precambrian ancestry of the Colorado Mineral Belt: Geological Society of America Bulletin, v. 74, p. 991-1014.

Tweto, Ogden, Steven, T.A., Hail, W.J., Jr., and Moench, R.H., 1976, Preliminary geologic map of the Montrose 1 degree by 2 degrees quadrangle, southwestern Colorado: U.S. Geological Survey Miscellaneous Field Studies Map MF-761, scale 1:250,000. [Also available at https://pubs.er.usgs.gov/ publication/mf761.]

U.S. Geological Survey, 2008, National Seismic Hazard Map: U.S. Geological Survey, Earthquakes Hazard Program, available at: https://earthquake.usgs.gov/hazards/hazmaps/ conterminous/index.php\#2008.

U.S. Geological Survey, 2010, Divisions of geological timeMajor chronostratigraphic and geochronological units: U.S. Geological Survey Fact Sheet 2010-3059, 2 p. [Also available at https://pubs.er.usgs.gov/publication/fs20103059.]

Van Alstine, R.E., 1971, Allochthonous Paleozoic blocks in the Tertiary San Luis-Upper Arkansas graben, Colorado, in James, H.L., ed., New Mexico Geological Society 22nd Annual Field Conference Guidebook 22, 340 p. [Also available at http:// nmgs.nmt.edu/publications/guidebooks/22/home.cfm.]

Van Alstine, R.E., 1974, Geology and mineral deposits of the Poncha Springs SE quadrangle, Chaffee County, Colorado: U.S. Geological Survey Professional Paper 829, 19 p., scale 1:24,000. [Also available at https://pubs.er.usgs.gov/ publication/pp829.]

Van Alstine, R.E., and Cox, D.C., 1969, Geology and mineral deposits of the Poncha Springs NE quadrangle, Chaffee County, Colorado, with a section of Fluorospar mines and prospects: U.S. Geological Survey Professional Paper 626, $52 \mathrm{p}$., scale 1:24,000. [Also available at https://pubs.er.usgs. gov/publication/pp626.]

Van Alstine, R.E., and Lewis, G.E, 1960, Pliocene sediments near Salida, Chaffee County, Colorado, in Short papers in the geological sciences, Geological Survey research 1960: U.S. Geological Survey Professional Paper 400-B, p. B245. [Also available at https://pubs.er.usgs.gov/publication/pp400B.]
Varnes, D.J., Radbruch-Hall, D.H., and Savage, W.Z., 1989, Topographic and structural conditions in areas of gravitational spreading of ridges in the Western United States: U. S. Geological Survey Professional Paper 1496, 32 p. [Also available at https://pubs.er.usgs.gov/publication/pp1496.]

Varnes, D.J., Radbruch-Hall, D.H., Varnes, K.L., Smith, W.K., and Savage, W.Z., 1990, Measurement of ridge-spreading movements (sackungen) at Bald Eagle Mountain, Lake County, Colorado, 1975-1989: U. S. Geological Survey Open-File Report 90-543, 13 p. [Also available at https:// pubs.er.usgs.gov/publication/ofr90543.]

Varnes, D.J., Coe, J.A., Godt, J.W., Savage, W.Z., and Savage, J.E., 2000, Measurement of Colorado, II-Continuation of the 1975-1989 measurements using a Global Positioning System in 1997 and 1999: U.S. Geological Survey Open File Report 00-205, 23 p. [Also available at: https://pubs. er.usgs.gov/publication/ofr00205.]

Vick, S.G., 1981, Morphology and the role of landsliding in the formation of some rock glaciers in the Mosquito Range, Colorado: Geological Society of America Bulletin, Part 1, v. 92 , p. $75-84$.

Voynick, S.M., 1994, Colorado rockhounding: Missoula, Mont., Mountain Press Publishing Company, 371 p.

Wallace, A.R., 1993, Geologic setting of the Leadville mining district, Lake County, Colorado: U.S. Geological Survey Open-File Report 93-343, 19 p. [Also available at https:// pubs.er.usgs.gov/publication/ofr93343.]

Wallace, C.A., Cappa, J.A., and Lawson, A.D., 1997, Geological map of the Salida East quadrangle, Chaffee and Fremont Counties, Colorado: Colorado Geological Survey Open-File Report 97-6, 27 p., scale 1:24,000.

Wallace, C.A., and Keller, J.W., 2003, Geologic map of the Castle Rock Gulch quadrangle, Chaffee and Park Counties, Colorado: Colorado Geological Survey Open-File Report 03-1, scale 1:24,000.

Wallace, C.A., and Keller, J.W., McCalpin, J.P., Bartos, P.J., Route, E.E., Jones, N.N., Gutierrez, Francisco, Williams, C.L., and Morgan, M.L, 2002, Geologic map of the Breckenridge quadrangle, Summit and Park Counties, Colorado: Colorado Geological Survey Open-File Report 02-7, 44 p., scale 1:24,000.

Wallace, C.A., and Lawson, A.D., 1998, Geologic map of the Cameron Mountain quadrangle, Chaffee, Park, and Fremont Counties, Colorado: Colorado Geological Survey Open-File Report 98-4, 23 p., scale 1:24,000.

Ward, D.J., Anderson, R.S., Guido, Z.S., and Briner, J.P., 2007, Numerical modeling of cosmogenic deglaciation records, Front Range and San Juan Mountains, Colorado: Journal of Geophysical Research, v. 114, F01026, doi: 10.1029/2008JF001057. 
Wetherill, G.W., and Bickford, M.E., 1965, Primary and metamorphic Rb-Sr chronology in central Colorado: Journal of Geophysical Research, v. 70, no. 18, p. 4669-4686.

White, S.E., 1971, Rock glacier studies in the Colorado Front Range, 1961 to 1968: Arctic and Alpine Research, v. 3, p. 43-64.

White, S.E., 1976, Rock glaciers and block fields, review and new data, 1961 to 1968: Quaternary Research, v. 6, p. 77-97.

Widmann, B.L., Bartos, P.J., Madole, R.F., Barba, K.E., and Moll, M.E., 2004, Geologic map of the Alma quadrangle, Park and Summit counties, Colorado: Colorado Geological Survey Open-File Report 04-3, scale 1:24,000.

Widmann, B.L., Kirkham, R.M., Keller, J.W., Poppert, J.T., and Price, J.B., 2005, Geologic map of the Como quadrangle, Park County, Colorado: Colorado Geological Survey Open-File Report 05-4, scale 1:24,000.

Widmann, B.L., Kirkham, R.M., Houck, K.J., and Lindsay, N.R., 2007, Geologic map of the Fairplay West quadrangle, Park County, Colorado, Colorado Geological Survey OpenFile Report 06-7, scale 1:24,000.

Widmann, B.L., Kirkham, R.M., Houck, K.J., and Lindsay, N.R., 2011, Geologic map of the Jones Hill quadrangle, Park County, Colorado: Colorado Geological Survey OpenFile Report 11-04, scale 1:24,000.
Worcester, P.G., 1919, Molybdenum deposits of Colorado: Colorado Geological Survey Bulletin 14, 131 p.

Wrucke, C.T., 1974, The Whitehorn Granodiorite of the Arkansas Valley in central Colorado: U.S. Geological Survey Bulletin 1394-H, p. 1-7. [Also available at https:// pubs.er.usgs.gov/publication/b1394H.]

Wrucke, C.T. and Dings, M.G., 1979, Geologic map of the Cameron Mountain quadrangle, Colorado: U.S. Geologic Survey Open-File Report 79-660, scale 1:62,500. [Also available at https://pubs.er.usgs.gov/publication/ofr79660.]

Xu Tianguang, 2001, Sedimentology and stratigraphy of Tertiary continental deposits in the Poncha Pass transfer zone and adjacent area, Colorado: Manhattan, Kan., Kansas State University M.S. thesis, 98 p.

Young, N.E., Briner, J.P, Leonard, E.M., Licciardi, J.M., and Lee, Keenan, 2011, Assessing climatic and nonclimatic forcing of Pinedale glaciation and deglaciation in the western US: Geology, v. 39, no. 2, p. 171-174.

Zimmerer, M.U., and McIntosh, W.C., 2012, An investigation of caldera-forming magma chambers using the timing of ignimbrite eruptions and pluton emplacement at the Mt. Aetna caldera complex: Journal of Volcanology and Geothermal Resources, v. 245-246, p. 128-148.
Publishing support provided by:

Denver Publishing Service Center

For more information concerning this publication, contact:

Center Director, USGS Geosciences and Environmental Change

Science Center

Box 25046, Mail Stop 980

Denver, CO 80225

(303) 236-5344

Or visit the Geosciences and Environmental Change Science Center Website at:

https://gec.cr.usgs.gov/ 



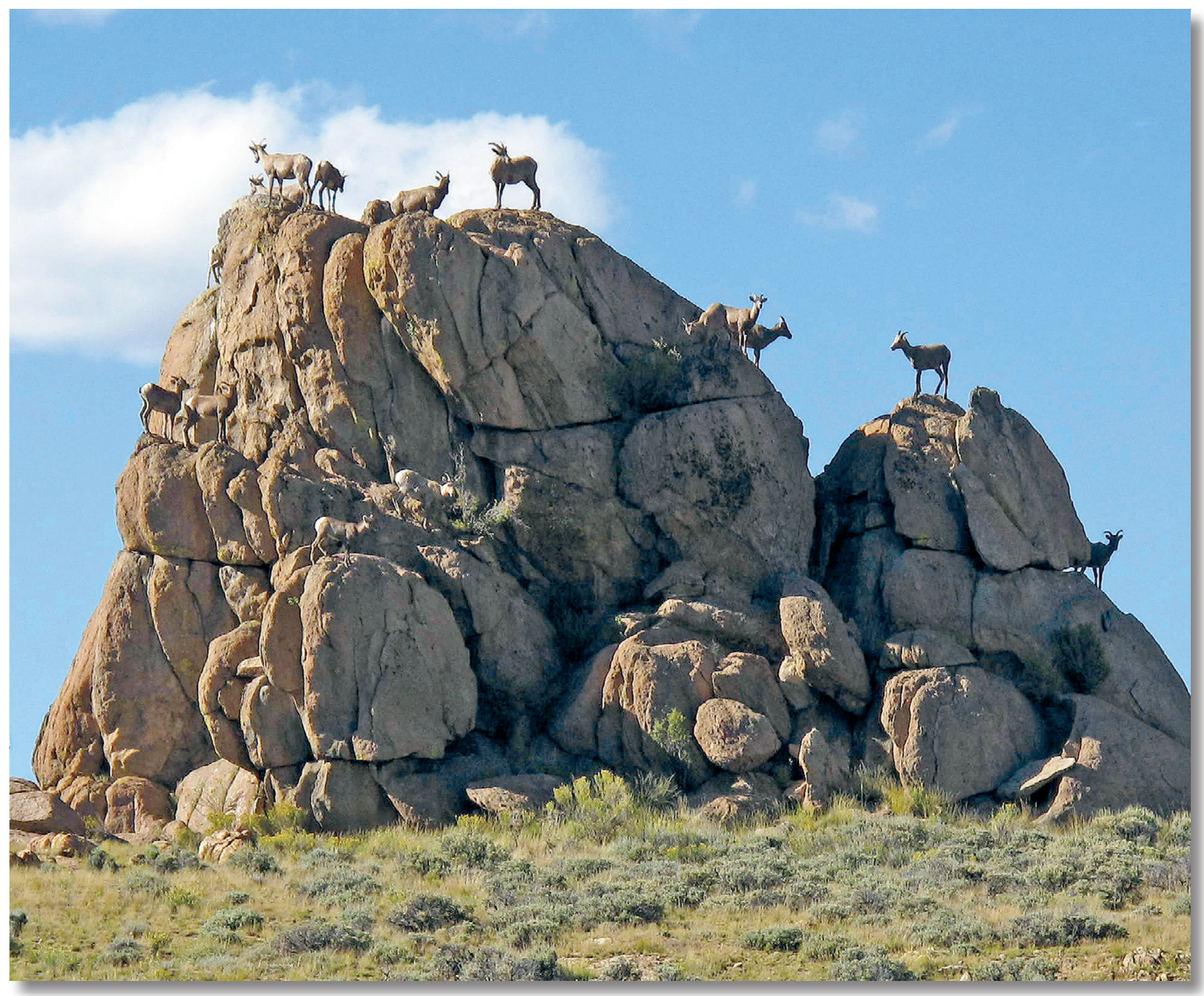

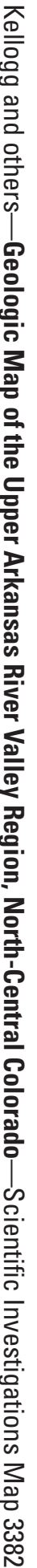

